\title{
LUÍSIANE DE ÁVILA SANTANA
}

Tratamento de Úlceras Venosas por Ultra-Som de Baixa Intensidade: Avaliação por Análise de Imagem e Imunohistoquímica

Dissertação apresentada ao Programa de PósGraduação em Interunidades Bioengenharia Escola de Engenharia de São Carlos, Faculdade de Medicina de Ribeirão Preto e Instituto de Química de São Carlos da Universidade de São Paulo, como parte dos requisitos para obtenção do título de Mestre em Bioengenharia.

Orientador: Prof. Dr. José Marcos Alves

\section{São Carlos}


Ficha catalográfica preparada pela Seção de Tratamento da Informação do Serviço de Biblioteca - EESC/USP
S232t Tratamento de úlceras venosas por ultra-som de baixa intensidade : avaliação por análise de imagem e imunohistoquímica / Luísiane de Ávila Santana -- São Carlos, 2006 .

Dissertação (Mestrado) - - Escola de Engenharia de São Carlos/Faculdade de Medicina de Ribeirão Preto/ Instituto de Química de São Carlos-Universidade de São Paulo, 2006 .

Área: Bioengenharia.

Orientador: Prof. Dr. José Marcos Alves.

1. Úlcera. 2. Ultra-som. 3. Análise de imagem. 4. Sulfadiazina de prata. I. Título. 


\section{DEDICATÓRIA}

Dedico este trabalho:

aos meus maravilhosos pais Jussara e José Luiz;

à minha querida irmã Josiane e ao meu namorado, minha grande companhia Leandro. 


\section{AGRADECIMENTOS}

\section{Ao Grande Arquiteto do Universo: Deus}

Por sempre iluminar meu caminho, dando-me grandes oportunidades.

\section{Aos pacientes}

Pela satisfação de poder fazer o bem.

\section{À minha família}

Pai, mãe e irmã, pelo carinho e confiança que depositaram em mim, mas principalmente por serem estas pessoas tão maravilhosas e me tratarem infinitamente bem.

\section{Ao meu amor Leandro}

Pela paciência, compreensão e conselhos nos momentos difíceis e, principalmente, por sempre estar ao meu lado.

\section{Ao meu orientador Prof. Dr. José Marcos Alves da EESC-USP}

Pela confiança em mim depositada, acreditando em mim para a realização deste trabalho.

\section{À Prof.Dra. Norma Tiraboschi Foss da FMRP-USP}

Por incentivar e disponibilizar a infraestrutura da Divisão de Dermatologia da FMRP-USP para a realização deste trabalho.

\section{Ao Prof.Dr. Marco Andrey Cipriani Frade da FMRP-USP}

Pela co-orientação, carinho, incentivo, amizade e ensinamentos diários sobre cicatrização que vieram a enriquecer muito meu conhecimento.

\section{Ao Prof.Dr. João Kazuyuki Kajiwara da FMRP-USP}

Pelos ensinamentos e infraestrutura de software sobre análise de imagem, atenção e disposição em sempre me atender.

\section{Ao Prof.Dr. Sérgio Britto Garcia da FMRP-USP}

Pela importante contribuição nas análises de imunohistoquímica e histopatologia. 
Ao Prof.Dr. Fernando de Queiróz Cunha e Prof.Dr. Fernando Morgan de Aguiar Corrêa da FMRP-USP

Pela importante colaboração nos procedimentos de imunohistoquimica e microscopia.

Aos docentes e funcionários do Departamento de Clínica Médica/Divisão de Dermatologia da FMRP-USP

Por sempre me receberem com muito carinho.

Aos funcionários do Centro Saúde Escola (CSE) da FMRP-USP

Em especial as enfermeiras Shirlei e Daniela pela atenção.

Aos funcionários do Programa de Pós-Graduação Interunidades Bioengenharia - USP

Pelo carinho e colaboração.

Ao pessoal do "Laboratório de Farmacologia" da FMRP-USP

Por sempre me receberem com muita atenção.

Ao pessoal do "Laboratório de Patologia" da FMRP-USP

Em especial a Rose pela ajuda e disposição em me atender sempre com muito carinho.

Aos funcionários da "Oficina de Precisão" da FMRP-USP

Pela colaboração na realização deste trabalho.

\section{À familia Sanchez dos Reis}

João Alberto, Sueli, Danilo, Carol, Rodrigo, Gi e Idavina, por sempre me acolherem.

\section{À amiga Fernanda}

Pelos conselhos e ajudas em todos os momentos em que precisei, mas principalmente pelo seu carinho e amizade.

Ao amigo Thiago

Pela colaboração da realização dos trabalhos de histologia e imunohistoquímica, realizados sempre com muita dedicação. 
Às minhas amigas de república

Mirian e Mariana pela amizade e o carinho.

"...desconfie do destino e acredite em você.

Gaste mais horas realizando que sonhando,

fazendo que planejando, vivendo que esperando.

Porque, embora quem quase morreu esteja vivo, quem quase vive já morreu." Sarah Westphal Batista da Silva. 


\section{RESUMO}

SANTANA, L. A. Tratamento de Úlceras Venosas por Ultra-Som de Baixa Intensidade: Avaliação por Análise de Imagem e Imunohistoquímica. 2006. 126 f. Dissertação (Mestrado) - Programa de Pós-Graduação Interunidades em Bioengenharia (EESC/FMRP/IQSC), Universidade de São Paulo, São Carlos, 2006.

Úlceras de perna acometem as extremidades dos membros inferiores e são causadas por alguma disfunção do sistema vascular. A cicatrização das úlceras é um processo dinâmico que envolve fenômenos biológicos, bioquímicos e imunológicos. A avaliação clínica da evolução das úlceras é difícil e se baseia nas modificações teciduais como granulação, fibrina/esfácelo e reepitelização. A avaliação clínico terapêutica adequada compreende da avaliação da área das úlceras e das áreas correspondentes aos diferentes tecidos presentes nas mesmas. Inúmeras são as opções terapêuticas objetivando a cicatrização das úlceras, envolvendo os mais variados estímulos imunobiológicos, sendo importante a avaliação imunohistoquímica da evolução do tratamento. Estudos anteriores demonstraram que o ultra-som de baixa intensidade (US) estimula a reparação tecidual de úlceras de perna. Com base nestes estudos esta investigação tem o objetivo de comparar a eficácia do ultra-som de baixa intensidade $\left(30 \mathrm{~mW} / \mathrm{cm}^{2}\right)$ e de curativos diários á base de sulfadiazina de prata $1 \%$ na cicatrização de úlceras venosas, com as seguintes implementações: a) modificação da técnica de antissepsia para aplicação do ultra-som no tratamento das úlceras; b) padronização da técnica de captura da imagem das úlceras; c) utilização de nova técnica de quantificação do tratamento das úlceras e dos seus tecidos (granulação e fibrina/esfácelo) usando o software livre Image ${ }^{\circledR}$ para quantificar a área da úlcera e dos seus tecidos; d) quantificação dos fatores de crescimento TGF- $\beta$ e VEGF e da enzima iNOS nas biópsias iniciais e no $45^{\circ}$ dia do tratamento das úlceras. Nesta investigação foram tratadas dezesseis úlceras de perna do tipo venosa no Ambulatório de Úlcera da Dermatologia do Centro Saúde Escola (CSE) - HCFMRP - USP. Elas foram divididas em dois grupos experimentais: Grupo 1 (7 úlceras) em que foi utilizado tratamento com curativos diários á base de sulfadiazina de prata 1\%; Grupo 2 (9 úlceras) em que foi utilizado tratamento com US 3 vezes por semana seguido de curativos diários com gazes umedecidas com soro fisiológico ou 
vaselina, conforme necessidade do paciente. Os pacientes tiveram um protocolo de 90 dias de tratamento e através de fotografias padronizadas as úlceras foram analisadas quantitativamente no início e a cada 15 dias de tratamento para 0 cálculo das áreas da úlcera, granulação e fibrina/esfácelo, através do Image ${ }^{\circledR}$. Uma película de látex (preservativo) e gel no cabeçote do transdutor causa pequena atenuação no ultra-som e melhora a assepsia do tratamento das úlceras. A técnica de quantificação da cicatrização de úlceras através de análise de imagem pelo software Image $^{\circledR}$ foi validada e comparada com técnicas convencionais de monitoramento do tratamento de úlceras. O cálculo da área das úlceras pelo Image $^{\circledR}$ tem um erro médio de $4,8 \%$ mas não há diferença estatística, por método não paramétrico, nos resultados de quantificação pelo software quando comparado às técnicas convencionais ou quando são utilizados métodos padronizados e não padronizados de captura das imagens. Não há influência da segmentação manual das imagens das úlceras por diferentes usuários nos resultados das análises realizadas pelo Image $J^{\circledR}$. Houve aumento, não estatisticamente significante, na presença da enzima iNOS e dos fatores de crescimento TGF $\beta$ e VEGF nas úlceras tratadas por ultra-som. Houve uma aceleração estatisticamente significante na cicatrização das úlceras, na formação do tecido de granulação e na redução do tecido de fribrina/esfácelo do tratamento com ultra-som quando comparado ao tratamento com sulfadiazina de prata $1 \%$.

Palavras chaves: úlcera, ultra-som, sulfadiazina de prata, análise de imagem 


\section{ABSTRACT}

SANTANA, L. A. Treatment of venous ulcers by low intensity ultrasound: Assessment by Image Analysis and Immunohistochemitry. 2006. 126 f. Master Dissertation - Bioengineering Graduate Program, University of São Paulo at São Carlos, 2006.

Chronic venous ulcers affect inferior members due to some vascular system disorders. The healing process is dynamic and involves biological, biochemical and immunological phenomenon. The clinical follow up is difficult and based on tissue alterations like fibrin, granulation and new epithelization. The therapeutic and clinical follow up should take into account the ulcer area as well as the area of the ulcer tissues. A large number of therapeutic procedures are available to heal ulcers and they are based on immunological stimulus which makes important to investigate the immunohistochemistry response of the treatment. Previous studies shown that low intensity ultrasound (US) stimulates the tissue repair of leg ulcers. The aim of this investigation is to compare the effectiveness of the US treatment with respect to dressings of silver sulfadiazine $1 \%$ on the healing of venous ulcers using a different methodology for carrying out what follows: a) the improvement of US treatment asepsis; b) the capturing of the ulcers image with a standardized method; c) the image analysis with a freeware software $\left(\right.$ Image $\left.J^{\circledR}\right)$ to quantify the area of the ulcer and its tissues along the ulcer treatment. d) the quantification of the growth factors TGF- $\beta$ e VEGF and the enzyme iNOS in biopsies taken on the first and 45th day of the treatment to assess the immunohistochemitry changes. In this investigation sixteen leg chronic venous ulcers were treated at the "Ulcer Outpatient Clinic of Dermatology", Teaching Health Center, General Hospital, College of Medicine of Ribeirão Preto, University of São Paulo at Ribeirão Preto. The ulcers were randomly separated in two experimental groups: Group 1,7 ulcers were treated with daily dressings of silver sulfadiazine 1\%; Group 2, 9 ulcers were treated with low intensity ultrasound three times a week followed by daily dressings with humidified gauzes on physiologic sore or vaselin. The protocol last 90 days and photographs of the ulcers were taken every 15 days to quantify the area of the ulcer and its tissues (granulation and fibrin) through the Image $J^{\circledR}$ software. A thin layer of latex (condom) and gel cause a small attenuation of the ultrasound energy and improves the asepsis of the 
treatment. The image analysis technique using Image $\mathrm{J}^{\circledR}$ was validated and compared with conventional methods of monitoring ulcers treatment. The calculation of the ulcers area by the Image $J^{\circledR}$ has an average error of $4,8 \%$. There is no statistical difference in the results of monitoring ulcers treatment through this method and the conventional ones. The error of a standardized method for capturing the ulcers image did not show statistical difference when compared to a nonstandardized method. The manual segmentation of the ulcer image by different users do not influence the results of the image analysis by the Image ${ }^{\circledR}$. The increase in the enzyme iNOS and growth factors TGF $\beta$ and VEGF in the ulcers treated by US is not statistically significant. There is a statistical significance in the treatment of ulcers by US when compared to dressings of silver sulfadiazine $1 \%$ with respect to area decrease and the formation of granulation and fibrin tissues. The low intensity ultrasound accelerates the healing process of the ulcers.

Key words: ulcer, ultrasound, silver sulfadiazine, image analysis 


\section{Lista de Tabelas}

\begin{tabular}{|c|c|c|}
\hline Tabela & & Pág. \\
\hline 4.1 & Influência da Película de Látex & 75 \\
\hline 4.2 & Dados populacionais do grupo 1 (SDZ) e do grupo 2 (US) & 76 \\
\hline 4.3a & Razão $r_{1}$ das úlceras de perna do grupo 1 (SDZ) & 81 \\
\hline $4.3 b$ & Razão $r_{1}$ das úlceras de perna do grupo 2 (US) & 82 \\
\hline 4.4 & Evolução de $r_{1}$ com o tempo & 83 \\
\hline $4.5 a$ & Razão $r_{2}$ das úlceras de perna do grupo 1(SDZ) & 84 \\
\hline $4.5 b$ & Razão $r_{2}$ das úlceras do grupo 2 (US) & 85 \\
\hline $4.6 a$ & Razão $r_{3}$ das úlceras do grupo $1(S D Z)$ & 86 \\
\hline $4.6 b$ & Razão $r_{3}$ das úlceras do grupo 2 (US) & 87 \\
\hline 4.7 & $\begin{array}{l}\text { Análise imunohistoquímica das biópsias das úlceras segundo } \\
\text { a área marcada de iNOS, TGF } \beta \text { e VEGF no } 1^{0} \text { dia e } 45^{\circ} \text { dia } \\
\text { de tratamento nas úlceras dos pacientes do Grupo } 1 \text { (SDZ) e } \\
\text { Grupo } 2 \text { (US }\end{array}$ & 88 \\
\hline 4.8 & Valor Médio da massa do papel com área padrão de $1 \mathrm{~cm}^{2}$ & 89 \\
\hline 4.9 & Validação da Medida da Área & 90 \\
\hline 4.10 & Comparação entre Câmara Digital e Método Manual & 91 \\
\hline 4.11 & Comparação entre Técnica Convencional e Image ${ }^{\circledR}$ & 91 \\
\hline 4.12 & Comparação entre método padronizado e não padronizado & 92 \\
\hline 4.13 & Influência Humana no uso do Software Image ${ }^{\circledR}$ & 93 \\
\hline 4.14 & Resultados Estatísticos da Análise das Áreas das Úlceras & 95 \\
\hline 4.15 & Resultados Estatísticos da Análise da Imunohistoquímica & 96 \\
\hline 4.16 & Estudos 1 a 3 - Resultados Estatísticos & 97 \\
\hline 4.17 & Estudo 4 - Resultados Estatísticos & 98 \\
\hline 4.18 & Estudo 5 - Resultados Estatísticos & 98 \\
\hline
\end{tabular}




\section{Lista de Tabelas (continuação)}

\begin{tabular}{l|lc}
\hline Tabela & & Pág. \\
\hline $8.1 \mathrm{a}$ & Evolução das áreas das úlceras de perna do grupo 1(SDZ) & 124 \\
$8.1 \mathrm{~b}$ & Evolução das áreas das úlceras de perna do grupo 2 (US) & 124 \\
$8.2 \mathrm{a}$ & Evolução das áreas do tecido de granulação do grupo 1 (SDZ) & 125 \\
$8.2 \mathrm{~b}$ & Evolução das áreas do tecido de granulação do grupo 2 (US) & 125 \\
$8.3 \mathrm{a}$ & Evolução das áreas do tecido de fibrina do grupo 1 (SDZ) & 126 \\
$8.3 \mathrm{~b}$ & Evolução das áreas do tecido de fibrina do grupo 2 (US) & 126 \\
\hline
\end{tabular}




\section{Lista de Figuras}

\begin{tabular}{l|ll}
\hline Figura & & Pág. \\
\hline 2.1 & Camadas da Pele & 25 \\
3.1 & Tratamento de úlcera por ultra-som & 59 \\
3.2 & Aparelho de ultra-som & 59 \\
3.3 & Representação esquemática dos meios com impedância & 60 \\
$3.4 a$ & acústica & \\
$3.4 b$ & Aparelho para câmera fotográfica & 64 \\
3.5 & Foto padração da utilização do aparelho & 64 \\
3.6 & Programa ImageJ ${ }^{\circledR}$ & 64 \\
$3.7 a$ & Ícone do Plugin polygon & 65 \\
$3.7 b$ & Ícone do Plugin rectangular & 66 \\
3.8 & Úlcera segmentada & 66 \\
3.9 & Imunohistoquímica segmentada & 66 \\
$3.10 a$ & Plugin threshold_colour & 69 \\
$3.10 b$ & Exemplo de uma imagem de úlcera com seleção de fibrina & 67 \\
3.11 & Imagem real da ferida & 67 \\
3.12 & Imagem com seleção de fibrina e imagem com seleção de & 67 \\
$3.13 a$ & granulação, respectivamente & 67 \\
$3.13 b$ & Imagem real da imunohistoquímica & 69 \\
3.14 & Plugin threshold & 69 \\
3.15 & Imagem com seleção da cor cobre & 69 \\
3.16 & Seleção de área de fibrina & 69 \\
\hline 3.17 & Seleção de área da cor cobre & 69 \\
\hline
\end{tabular}




\section{Lista de Figuras (continuação)}

\begin{tabular}{l|lc}
\hline Figura & & Pág. \\
\hline $4.1 \mathrm{a}$ & Seguimento clínico fotográfico dos pacientes do Grupo 1 & 77 \\
$4.1 \mathrm{~b}$ & Seguimento clínico fotográfico dos pacientes do Grupo 1 & 78 \\
$4.2 \mathrm{a}$ & Seguimento clínico fotográfico dos pacientes do Grupo 2 & 79 \\
$4.2 \mathrm{~b}$ & Seguimento clínico fotográfico dos pacientes do Grupo 2 & 80 \\
8.1 & Tissue Tek & 120 \\
$8.2 \mathrm{a}$ & Frente do criostato & 120 \\
$8.2 \mathrm{~b}$ & Interior do criostato & 120 \\
8.3 & Cortes das peças biopsiadas & 121 \\
8.4 & Lâminas em PBS no agitador orbital & 121 \\
8.5 & Cortes sendo pipetados & 123 \\
8.6 & Hematoxilina de Harris & 123 \\
8.7 & Bateria de álcoois e xilóis
\end{tabular}




\section{Lista de Gráficos}

\begin{tabular}{l|lc}
\hline Gráfico & & Pág. \\
\hline $4.1 \mathrm{a}$ & Razão $\mathrm{r}_{1}$ das úlceras de perna do grupo 1 (SDZ) & 81 \\
$4.1 \mathrm{~b}$ & Razão $\mathrm{r}_{1}$ das úlceras de perna do grupo 2 (US) & 82 \\
$4.2 \mathrm{a}$ & Razão $\mathrm{r}_{2}$ das úlceras de perna do grupo 1(SDZ) & 84 \\
$4.2 \mathrm{~b}$ & Razão $\mathrm{r}_{2}$ das úlceras do grupo 2 (US) & 85 \\
$4.3 \mathrm{a}$ & Razão $\mathrm{r}_{3}$ das úlceras do grupo 1(SDZ) & 86 \\
$4.3 \mathrm{~b}$ & Razão $\mathrm{r}_{3}$ das úlceras do grupo 2 (US) & 87 \\
\hline
\end{tabular}




\section{Sumário}

\begin{tabular}{|c|c|c|}
\hline & & Pág \\
\hline & $\begin{array}{l}\text { Resumo } \\
\text { Abstract } \\
\text { Lista de Tabelas } \\
\text { Lista de Figuras } \\
\text { Lista de Gráficos }\end{array}$ & \\
\hline 1 & Introdução & 19 \\
\hline 1.1 & Objetivos & 21 \\
\hline 2 & Revisão Bibliográfica & 22 \\
\hline 2.1 & Anatomia da Pele & 23 \\
\hline 2.1 .1 & Epiderme & 23 \\
\hline 2.1 .2 & Derme & 23 \\
\hline 2.2 & Fisiologia da Pele & 25 \\
\hline 2.2 .1 & Sistema Imune & 25 \\
\hline 2.2.1.1 & Mecanismo efetores da resposta imune & 28 \\
\hline 2.3 & Úlcera de Perna do Tipo Venosa & 29 \\
\hline 2.4 & Cura e Reparo Tecidual & 32 \\
\hline 2.4 .1 & Regeneração & 32 \\
\hline 2.4 .2 & Cicatrização & 33 \\
\hline 2.5 & Morfometria das Úlceras & 37 \\
\hline 2.6 & Tipos de Tratamento & 38 \\
\hline 2.7 & O Ultra-som & 40 \\
\hline 2.7 .1 & Bases Físicas do Ultra-som & 41 \\
\hline
\end{tabular}


Sumário (continuação)

\begin{tabular}{|c|c|c|}
\hline & & Pág \\
\hline 2.7 .1 .1 & Produção e Transmissão & 41 \\
\hline 2.7 .2 & Características das Ondas Ultra-sônicas & 42 \\
\hline 2.7 .3 & Modos de Propagação & 43 \\
\hline 2.8 & Interação do Ultra-som com os Tecidos & 43 \\
\hline 2.8 .1 & Impedância Acústica & 43 \\
\hline 2.8.1.1 & Reflexão e Refração & 44 \\
\hline 2.8.1.2 & Atenuação & 44 \\
\hline 2.8.1.3 & Campo Ultra-sônico & 45 \\
\hline 2.8 .2 & Efeitos Biológicos do Ultra-som & 45 \\
\hline 2.8.2.1 & Efeito Térmico & 45 \\
\hline 2.8.2.2 & Efeito não Térmico & 46 \\
\hline 2.8.2.3 & Forças de Radiação & 47 \\
\hline 2.9 & Ultra-som em Regeneração Óssea & 47 \\
\hline 2.10 & Efeitos do Ultra-som em Tecido Mole & 49 \\
\hline 2.11 & Sulfadiazina de prata & 54 \\
\hline 2.11 .1 & $\begin{array}{l}\text { Sulfadiazina de prata } 1 \% \text { no Tratamento das Úlceras de } \\
\text { Perna }\end{array}$ & 55 \\
\hline 3 & Metodologia & 56 \\
\hline 3.1 & Seleção dos Pacientes & 57 \\
\hline 3.2 & Padronização dos Grupos & 58 \\
\hline 3.3 & Técnica de Tratamento & 58 \\
\hline 3.3.1 & Transdutor Ultra- Sônico & 59 \\
\hline 3.4 & Assepsia da Úlcera & 62 \\
\hline
\end{tabular}


Sumário (continuação)

\begin{tabular}{|c|c|c|}
\hline & & Pág. \\
\hline 3.5 & Avaliação Clínica & 62 \\
\hline 3.6 & Avaliação Clinico Fotográfica & 62 \\
\hline 3.6 .1 & Captura da Imagem & 63 \\
\hline 3.7 & Detalhamento da Análise de Imagem & 64 \\
\hline 3.8 & Estudo Imunohistoquímico & 69 \\
\hline 3.9 & Parâmetros Quantificados & 70 \\
\hline 3.10 & Testes de Validação do Image $J^{\circledR}$ & 71 \\
\hline 3.11 & Análise Estatística & 73 \\
\hline 4 & Resultados & 74 \\
\hline 4.1 & Efeito da Camada de Látex na Transmissão do Ultra-som & 75 \\
\hline 4.2 & Dados Populacionais & 75 \\
\hline 4.3 & $\begin{array}{l}\text { Quantificação das Áreas das Úlceras e das Razões } r_{1}, r_{2} \text { e } \\
r_{3}\end{array}$ & 76 \\
\hline 4.4 & Imunohistoquímica & 88 \\
\hline 4.5 & Testes de Validação e Comparação do software Image $J^{\circledR}$ & 89 \\
\hline 4.6 & Resultados Estatísticos & 93 \\
\hline 5 & Discussão & 99 \\
\hline 6 & Conclusão & 105 \\
\hline 7 & Referências Bibliográficas & 107 \\
\hline 8 & Anexos & 116 \\
\hline
\end{tabular}


1. Introdução 
A úlcera venosa é causada principalmente por uma insuficiência venosa crônica, termo descrito como síndrome dos membros inferiores e que representa a incapacidade de manutenção do equilíbrio entre o fluxo de sangue arterial que chega ao membro inferior e o fluxo venoso que retorna ao átrio direito, decorrente da incompetência do sistema venoso superficial e/ou profundo (BARROS, 2000; PITTA et al., 2000).

Inúmeras são as formas de tratamento que ajudam na cicatrização, dentre elas a sulfadiazina de prata $1 \%$ que possui ação bactericida e bacteriostática, destruindo e impedindo a proliferação dos microorganismos (WARD; SAFLLE, 1995). Diversos estudos demonstraram os benefícios da sulfadiazina de prata a $1 \%$ no tratamento tópico de lesões ulceradas de diversas etiologias, tais como úlceras venosas (BISHOP; COLS, 1992), e úlceras de decúbito (HINDRYCKX et al., 1990; KUCAN et al., 1981).

A estimulação ultra-sônica da regeneração óssea (EURO) é uma técnica não invasiva de tratamento de fratura (DUARTE, 1983) que motivou estudos em animais e clínicos no Brasil e no exterior sobre os efeitos do ultra-som de baixa intensidade na cicatrização de úlceras tróficas da pele (HILÁRIO, 1993; ANASTÁCIO et al., 2000), na qualidade óssea (ARAl et al., 1993;), na osseointegração de implantes (TANZER et al., 1995), no reparo ósseo em artrodese de coluna (GLAZER et al., 1998) e no tratamento de fraturas mandibulares (VICENTE et al., 2000). O uso de ultra-som, como recurso terapêutico em úlceras tróficas, baseia-se em pesquisas com evidências consideráveis de que esse pode estimular a reparação tecidual e melhorar o desempenho mecânico do tecido cicatricial resultante. O real efeito do ultra-som sobre os tecidos ainda é pouco conhecido. 
Os resultados satisfatórios relatados em pesquisa sobre o uso do ultra-som de baixa intensidade no tratamento de úlceras tróficas (HILÁRIO, 1993; ANASTÁCIO, 2000) estimularam a realização do estudo clínico dessa dissertação buscando-se avaliar quantitativamente os resultados terapêuticos através de análise de imagem e imunohistoquímica para um melhor entendimento do mecanismo de ação do ultra-som na cicatrização.

\subsection{Objetivos}

- Avaliação da eficácia do ultra-som pulsátil de baixa intensidade (US) na indução da cicatrização de úlceras venosas, comparando ao tratamento convencional de sulfadiazina de prata $1 \%$.

- Avaliação do efeito do uso de uma película de látex (condon) no cabeçote do transdutor de US com relação à atenuação da energia ultra-sônica.

- Padronização da técnica de captura de imagem para o seguimento clínico terapêutico das úlceras de perna.

- Utilização de análise de imagem, através de um software de domínio público, para a quantificação da área das úlceras e das áreas correspondentes aos tecidos das mesmas (esfácelo/fibrina e granulação) nos períodos de pré e pós-tratamento.

- Quantificação por análise de imagem dos fatores de crescimento TGF- $\beta$ e VEGF e da enzima iNOS por método imunohistoquímico nas biópsias das úlceras no início do tratamento e no $45^{\circ}$ dia de tratamento. 
2. Revisão Bibliográfica 


\section{1 Anatomia da Pele}

\subsubsection{Epiderme}

A epiderme é a parte mais externa da pele. Ela consiste em uma só camada de células colunares denominada de células basais. As células basais se dividem para formar queratinócitos, que correspondem à camada espinhosa. Os queratinócitos sintetizam proteínas insolúveis, que permanecem na célula e finalmente se tornam um componente importante (o estrato córneo) (figura 2.1). Há três tipos de células dentríticas na epiderme: o melanócito, que sintetiza pigmento (melanina); célula Langerhans, que serve como elemento da linha de frente nas reações imunes da pele e os corpúsculos de MerKel, cuja função não está claramente definida, mas parecem estarem relacionados à sensibilidade tátil (HABIF, 2005).

\subsubsection{Derme}

Segundo Zorn (2004), a derme é caracterizada pelo tecido conjuntivo, o qual envolve diversos tipos de células que se localizam num abundante material fibroso intercelular sintetizado pelas células e por suas funções de sustentações, preenchimento, defesa e nutrição. O tecido conjuntivo subdivide-se em tecidos conjuntivos frouxo, denso e especializado (figura 2.1).

As fibras elásticas que compõem o tecido conjuntivo são compostas principalmente de elastina, uma proteína capaz de distender-se em duas dimensões. Estas fibras cedem facilmente a trações mínimas, porém retornam 
facilmente a sua forma original. O colágeno é uma proteína fibrosa estrutural, encontrada nos tendões, na pele, nos vasos sanguíneos, nos ossos e nas cartilagens. Na pele, no entanto, os feixes de colágeno dispõem-se na forma de uma rede tridimensional, com os feixes se entrecruzando de modo que uma força aplicada em qualquer direção da pele será transmitida sempre como uma força de tração aos feixes de fibras de colágeno (VIDAL; MELLO, 1987; ZORN, 2004).

Os fibroblastos são as células mais abundantes do tecido conjuntivo e os principais responsáveis pela síntese de fibras colágenas.

O tecido conjuntivo é constituído também pela substância fundamental amorfa, uma mistura complexa de proteínas que preenche o espaço entre as células e as fibras do tecido. As proteoglicanas são capazes de incrementar o depósito de colágeno e reconstituir a matriz extracelular. As glicosaminoglicanas têm a função de sustentação e transporte molecular e também atuam na produção do colágeno. As glicoproteínas desempenham um grande papel não somente na interação entre células vizinhas, como também ajudam as células a aderirem sobre seus substratos.

No tecido conjuntivo encontram-se diversos tipos de células de defesa importantes no processo inflamatório. Os macrófagos são células de defesa com grande capacidade de fagocitose, atuam como elemento de defesa fagocitando restos de células, bactéria e partículas inertes que penetram no organismo. Os mastócitos são representados por grânulos citoplasmáticos constituídos de histamina que tem a função de aumentar a permeabilidade vascular e heparina, uma substância anticoagulante. A superfície do mastócitos contém receptores específicos para o anticorpo. Os plasmócitos aparecem em grande quantidade na inflamação crônica e são os responsáveis pela produção de anticorpos. Os 
leucócitos são células que circundam intimamente os vasos sanguíneos e quando necessário migram para o tecido conjuntivo. As células adiposas se tornam especializadas no armazenamento de energia. (ZORN, 2004; GUIRRO; GUIRRO, 2002).
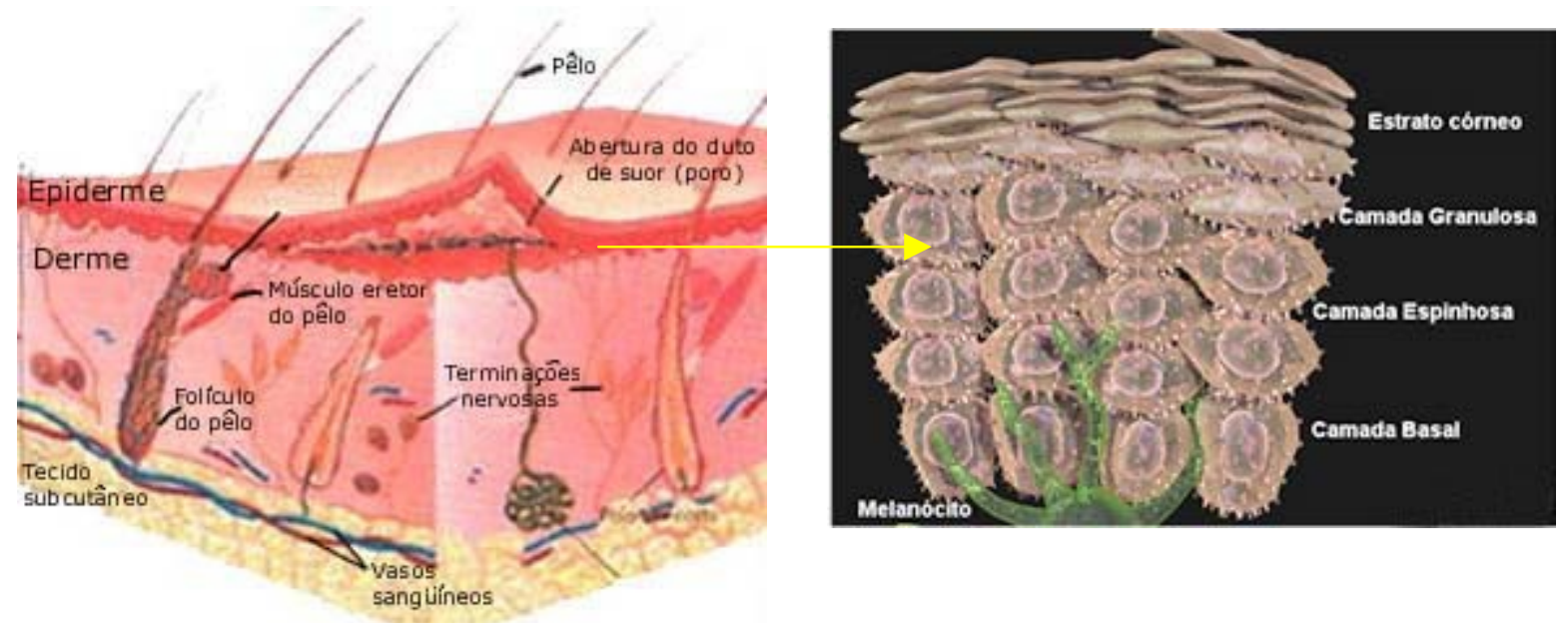

Figura 2.1 - Camadas da pele (ROSS; REITH. Histologia Texto e Atlas. p. 354. 1993)

\subsection{Fisiologia da Pele}

\subsubsection{Sistema Imune}

Ao se mencionar a cicatrização torna-se importante descrever o sistema imune.

O Sistema imunitário é formado por estruturas individualizadas: linfónodos e baço; células livres, como os linfócitos e granulócitos; células do sistema mononuclear fagocitário, presentes no sangue, na linfa e no tecido conjuntivo. Outro componente importante deste sistema são as células apresentadoras de antígenos, encontradas em muitos locais, como a pele (JUNQUEIRA; CARNEIRO, 2004a). 
As organizações anatômicas das células e dos tecidos do sistema imune têm uma importância crítica para a geração das respostas imunes. Essa organização permite que o pequeno número de linfócitos específicos localize o antígeno específico e responda eficazmente, independente do local do corpo onde o antígeno tenha sido introduzido (ABBAS et al., 2003).

A pele, graças aos componentes dérmicos participantes do SRE (sistema retículo endotelial), é um órgão de grande atividade imunológica, onde os componentes da imunidade humoral e celular atuam intensamente, motivo pelo qual, hoje, grande quantidade dos testes imunológicos, bem como práticas imunoterápicas, são estudadas na pele.

O sistema imunitário no seu conjunto é a segunda linha de defesa do organismo, cuja primeira barreira é constituída pela pele e mucosas, que tem um papel de defesa mecânica e química através da própria constituição do epitélio e das secreções (RIVITTI, 2001).

As células de Langerhans da epiderme são conhecidas como células apresentadoras de antígeno, elas apresentam os antígenos às células $\mathrm{T}$ e também são capazes de estimular células $T$ que ainda não entraram em contato com qualquer antígeno.

Os antígenos que penetram na pele são captados por células de Langerhans e transportados, via vasos linfáticos, para o linfonódo da região ou para o baço, onde se inicia uma resposta imune contra o antígeno (JUNQUEIRA; CARNEIRO, 2004b).

A resposta imunitária envolve, fundamentalmente, dois sistemas: a imunidade inata e a imunidade adquirida. O primeiro consiste de mecanismos que existem antes da inflamação. Ela proporciona as linhas iniciais de defesa contra os microorganismos. Os principais componentes da imunidade inata são as barreiras 
físicas e químicas, tais como epitélios e substâncias antimicrobianas produzidas nas superfícies epiteliais; as células fagocíticas (neutrófilos, macrófagos) e células matadoras naturais (NK); as proteínas do sangue, incluindo os membros do sistema complementar e outros mediadores da inflamação; as proteínas chamadas citocinas, que regulam e coordenam muitas das atividades das células da imunidade inata.

A imunidade adquirida consiste dos mecanismos de defesa mais altamente evoluídos, são estimulados pela exposição aos agentes infecciosos e aumenta em magnitude a capacidade defensiva em cada exposição sucessiva a um microorganismo em particular. Os principais componentes são os linfócitos, os quais expressam receptores de antígenos. Os linfócitos B fazem parte da imunidade humoral, eles podem se diferenciar em células que sintetizam e secretam anticorpos ativamente e os linfócitos T fazem parte da imunidade celular (RIVITTI, 2001; ABBAS et el., 2003).

Os linfócitos B e T expressam receptores para antígenos altamente distintos e específicos, que são operacionalmente definidos por duas características fundamentais: a) capacidade de induzir a resposta imune; b) capacidade de reagir especificamente com os anticorpos ou linfócitos sensibilizados resultantes da imunização (BIER et al., 1982).

Tanto os linfócitos B quanto os linfócitos T originam-se de um precursor comum na medula óssea. O desenvolvimento das células $B$ processa-se na medula óssea, enquanto que os precursores das células $\mathrm{T}$ migram para o timo e lá amadurecem. Depois do amadurecimento, as células B e T deixam respectivamente a medula óssea e o timo, entram na circulação e vão povoar os órgãos linfóides periféricos (ABBAS et al., 2003). 
Os linfonodos ou gânglios linfáticos também fazem parte do sistema imune. Eles são encontrados na axila, virilha, ao longo dos grandes vasos do pescoço e em grande quantidade no tórax e no abdômen.

A circulação da linfa no linfonodos é unidirecional. Ela atravessa os linfonodos penetrando nos vasos linfáticos que desembocam no órgão (vasos aferentes) e saindo pelos linfóticos do hilo (vasos eferentes).

O linfonodo é dividido por três regiões, sendo duas as mais importantes, a cortical superficial que apresenta células como os linfócitos $B$, ocorrendo também alguns plasmócitos, macrófagos e células foliculares dentríticas e a região cortical profunda ou paracortical, nela predominam os linfócitos T, ao lado de células reticulares, e alguns plasmócitos e macrófagos.

Os linfonodos são filtros da linfa, removendo partículas estranhas antes que a linfa retorne ao sistema circulatório sanguíneo (JUNQUEIRA; CARNEIRO, 2004a).

\section{2.1.1 Mecanismo Efetores da Resposta Imune}

As citocinas constituem uma família de proteínas que medeiam muitas das respostas da imunidade inata e adquirida. As mesmas citocinas podem ser produzidas por muitos tipos celulares. As citocinas são sintetizadas em resposta a estímulos inflamatórios ou antigênicos e em geral atuam localmente, de modo autócrino ou parácrino, pela ligação de receptores de alta afinidade nas células-alvo. Algumas citocinas podem ser produzidas em quantidade suficiente para circular e exercer ações endócrinas. Para muitos tipos celulares, as citocinas servem como fatores de crescimento. 
As citocinas que medeiam a imunidade inata são produzidas principalmente pelos macrófagos ativados e incluem: citocinas TNF e IL-1 que são mediadores de reações inflamatórias agudas aos microrganismos; as quimiocinas recrutam os leucócitos para os sítios de inflamação; citocinas IL-12 estimulam a produção da citocina IFN- $\mathrm{y}$ ativadora de macrófagos; os IFNs tipo I são citocinas antivirais e citocinas IL-10 são inibidores de macrófagos. Essas citocinas funcionam nas respostas imunes inatas a diferentes classes de microrganismos.

As citocinas que medeiam e regulam as fases de ativação e efetoras da imunidade adquirida são produzidas principalmente por linfócitos $\mathrm{T}$ antígenoestimulados, e incluem: citocina IL-2 que é o principal fator de crescimento das células T; citocina IL-4 que estimula a produção de $\lg \mathrm{E}$ e o desenvolvimento das células Th2 a partir das células T auxiliares virgens; citocina IL-5 que ativa os eosinófilos; citocina IFN-ץ é um ativador dos macrófagos; citocina TGF- $\beta$ que inibe a proliferação dos linfócitos T e ativação dos leucócitos.

Assim, as citocinas exercem muitas funções essenciais na defesa do hospedeiro contra patógenos e proporcionam ligações entre a imunidade inata e adquirida. A administração de citocinas ou de seus inibidores representa uma abordagem potencial para a modificação das respostas biológicas associadas a doenças imunes e inflamatórias (ABBAS et al., 2003).

\section{3 Úlcera de Perna do Tipo Venosa}

As úlceras de perna podem ser classificadas de acordo com a sua etiologia em venosas, arteriais, neuropáticas dentre outras. Em um estudo clínico com uma 
população de 124 de pacientes com úlcera de perna, 68\% dos pacientes tinham úlcera venosa (FRADE et al, 2001).

A idade (idosos), sexo (feminino), raça, obesidade, número de gestações, profissão (ortostatismo prolongado), constipação intestinal, vulnerabilidade das pernas a traumas e infecções, aumento da pressão venosa, diminuição do fluxo arterial e história familiar, são desencadeantes das varizes primárias (MAFFEI, 2002).

As úlceras venosas são causadas principalmente por uma insuficiência venosa crônica, termo descrito como síndrome dos membros inferiores e que representa a incapacidade de manutenção do equilíbrio entre o fluxo de sangue arterial que chega ao membro inferior e o fluxo venoso que retorna ao átrio direito decorrente da incompetência do sistema venoso superficial e/ou profundo, com sintomas como edema, pigmentação, dor e incapacidades (BARROS, 2000; PITTA et al., 2000). Em pessoas normais a pressão diminui durante os exercícios, já em pacientes com incompetência venosa a pressão permanece alta durante o esforço.

As úlceras venosas se caracterizam principalmente por edema, pigmentação escurecida, veias varicosas e lipodermatoesclerose (endurecimento e fibrose na derme e tecido subcutâneo) nos membros inferiores (PHILLIPS et al., 1991).

Poucos são os trabalhos publicados sobre a prevalência de úlceras de perna no Brasil. Maffei et al. (1986) em um estudo na região de Botucatu (SP), encontraram alta freqüência de úlcera venosa nos pacientes varicosos, freqüentemente desencadeadas por traumas. Os autores atribuíram esta alta freqüência à ausência de tratamento e pouco cuidado com esses pacientes na população de nível socioeconômico baixo. Na região de Belo Horizonte (MG), 
Cabral (2000) também encontrou alta prevalência $(2,6 \%)$ de úlceras venosas cicatrizadas ou abertas. Frade et al. (2001) avaliaram 124 pacientes da cidade de Juiz de Fora (MG) com o objetivo de traçar um perfil clínico - epidemiológico dos pacientes com úlceras de perna, avaliando os tipos mais freqüentes de úlcera, doenças associadas e o perfil sócio-econômico. Verificaram que a média de idade era 62,6 anos predominando sexo feminino $(65,3 \%)$ e renda menor que $\mathrm{R} \$ 540,00$ (86,8\%). Associavam-se às úlceras, insuficiência venosa $(74,2 \%)$, hipertensão arterial sistêmica (HAS) $(51,6)$ e diabetes melitus $(20,2 \%)$. As úlceras foram classificadas como venosa $(67,8 \%)$, hipertensivas $(20,1 \%)$, mistas e outras $(12,1$ \%). Elas acometiam preferencialmente o terço distal das pernas, $40 \%$ do tamanho médio $\left(2\right.$ a $\left.5 \mathrm{~cm}^{2}\right)$ e $35,6 \%$ grande $\left(>5 \mathrm{~cm}^{2}\right)$ e eram acompanhadas, principalmente, de hipercromia $(92,5 \%)$, lipodermatoesclerose $(68,8 \%)$ e varicosidades $(67,7 \%)$, com duração média de 94, 2 meses e $50 \%$ recidivantes. Todos os pacientes avaliados faziam curativos comunitários (em casa ou nos centros de atendimento à saúde), sendo curativos demorados e dispendiosos.

Trabalhos como o de Maffei et al. (1986), Cabral (2000) e Frade et al. (2001) mostraram a cronicidade e a importância da doença úlcera de perna na sociedade atual, o que instiga novas investigações sobre novos tratamentos para as mesmas, principalmente as venosas, com o intuito de melhorar a qualidade de vida desses pacientes. 


\section{4 Cura e Reparo Tecidual}

A reação do organismo frente a lesões que levam a uma solução de continuidade tecidual inicia-se precocemente com o processo inflamatório e ao final leva à regeneração ou à cicatrização dos tecidos lesados.

A reparação não pode ser considerada exclusivamente pela regeneração das células parênquimatosas, mesmo naqueles órgãos cujas células são capazes de regeneração. Assim, ocorrem tentativas de reparar a lesão tecidual mediante a substituição de células parênquimatosas não regeneradas por tecido conjuntivo, que com o tempo, produz fibrose e formação da cicatriz. Existem quatro componentes nesse processo: formação de novos vasos sanguíneos (angiogênese), migração e proliferação de fibroblastos, deposição de matriz extracelular, maturação e organização do tecido fibroso, também conhecido como remodelagem (MITCHELLI, 2005).

\subsubsection{Regeneração}

A regeneração corresponde à substituição das células parenquimais do mesmo tipo, com o propósito de recuperar a estrutura e a função do tecido original, deixando pouco ou nenhum vestígio da lesão inicial. Para que ocorra uma regeneração do tecido lesado, a arquitetura do tecido conjuntivo tem que estar intacta. Embora as células lábeis e estáveis sejam capazes de regeneração, o arcabouço ou estroma de apoio das células parenquimais deve estar presente para permitir uma reconstituição perfeita da estrutura tecidual. 
No entanto, após o nascimento do ser humano, o organismo falha em seu objetivo final de neoformar (regenerar) o tecido lesado, ocorrendo então o chamado reparo tecidual ou cicatrização (MITCHELLI, 2005).

\subsubsection{Cicatrização}

Ao contrário da regeneração, a cicatrização ocorre se a estrutura da matriz extracelular estiver danificada, causando alterações na arquitetura tecidual.

As arquiteturas da matriz extracelular são essenciais à cicatrização da ferida, pois elas fornecem a estrutura para migração celular e mantêm a polaridade celular correta para a remontagem das estruturas de multicamadas. Além disso, as células na matriz extracelular (fibroblastos, macrófagos e outros tipos de células) são as fontes de agentes críticos à reparação tecidual.

A cicatrização consiste na reposição do tecido normal por tecido conjuntivo fibroso no local de um traumatismo. É representada por uma seqüência de eventos moleculares que objetivam restaurar o tecido que sofreu injúria (PICCINATO et al., 2003).

No processo de cicatrização da ferida está envolvida uma série de fases, que ocorrem simultaneamente durante o reparo. Porém são divididas didaticamente como: injúria, coagulação, inflamação, formação tecidual e remodelagem tecidual (ARNOLD; WEST, 1991; KIRSNER; EAGLSTEIN, 1993).

\section{Injúria}

A lesão tecidual promove dano vascular que cursa com extravasamento sanguíneo, preenchendo a área lesada com plasma, elementos celulares (plaquetas) e proteínas plasmáticas (fibrinogênio e fibronectina). As células lesadas 
na injúria vão produzir citocinas e fatores de crescimento, como o fator de crescimento derivado de plaqueta (PDGF) e os fatores de transformação do crescimento beta e alfa (TGF $\beta$ e TGFa) (KARUKONDA et al., 2000).

\section{Coagulação}

Ocorre logo após a injúria. Os vasos lesionados contraem-se, para prevenir qualquer perda subseqüente de sangue, neste mesmo instante, juntamente com a coagulação sanguínea, ocorre o fenômeno de agregação plaquetária no local, resultando na formação de um coágulo fibrinoso que ocupa os espaços causados pela injúria.

As plaquetas extravasadas aderem ao colágeno no espaço perivascular, onde a trombina (proteína) induz a degranulação das plaquetas liberando PDGF, TGF $\beta$, TGFa, fator de crescimento epidérmico (EGF), fator de crescimento dos fibroblastos (FGFs) e fator de crescimento "insulin-like" (ILGF-1) (CHETTIBI; FERGUSON, 1999; KARUKONDA et al., 2000).

Os neutrófilos são as primeiras células migrantes que se dirigem para o leito da ferida. Sua função é fagocitar e eliminar qualquer bactéria presente na área.

Logo após os neutrófilos, os macrófagos derivados de monócitos começam a acumular-se no local da injúria. Seu papel é ser coadjuvante aos neutrófilos na fagocitose de microrganismos e debris teciduais, bem como na remoção de neutrófilos exauridos (CHETTIBI; FERGUSON, 1999; ARNOLD; WEST, 1991).

\section{Inflamatória}

Ocorre de 1 à 5 dias após a injúria. Durante a inflamação as células predominantes são: neutrófilos, macrófagos e linfócitos.

A inflamação é fundamentalmente uma resposta de proteção, mas pode ser potencialmente nociva. 
Os neutrófilos iniciam o processo de destruição de antígenos e a cicatrização propriamente dita. São os primeiros produtores de citocinas proinflamatórias (TNFa e IL-1 $\beta$ ) e também liberam o fator de crescimento TGF $\beta$.

Os macrófagos têm função antimicrobiana e de fagocitose, proporcionada pelo óxido nítrico e radicais de oxigênio, desbridamento da ferida (fagocitose, colagenase e elastase), regulação da síntese da matriz, liberando diversos fatores

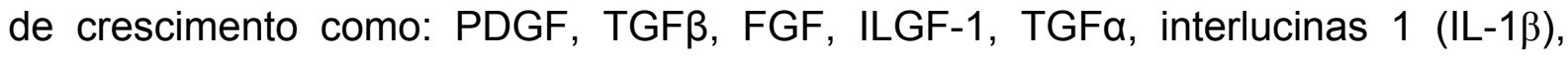
EGF, fator de necrose tumoral (TNFa), além de recrutamento e ativação das células e angiogênese.

Esta fase estimula a enzima Oxido Nítrico Sintase Induzida (iNOS) a produzir Óxido nítrico (NO), pois o iNOS é estimulado pelas citocinas pró-inflamatórias. Esta enzima é importante na cicatrização para ajudar no desbridamento da ferida. Porém, quando exagerado, pode levar a cronicidade da úlcera (CHILDRESS; STECHMILLER, 2002).

Os linfócitos também liberam o TGF $\beta$, além do interferon (IFN) e das interlucinas 2 (IL-2) (CHETTIBI; FERGUSON, 1999; ARNOLD; WEST, 1991; KARUKONDA et al., 2000).

\section{Formação Tecidual}

Ocorre entre o $3^{\circ}$ e $12^{\circ}$ dia após a injúria. A reepitelização é iniciada pela migração de células epiteliais desde as margens da ferida. Os estímulos responsáveis por essa migração são os mesmos atuantes nos fibroblastos, principalmente o EGF (BURGESS, 1989). Além disso, a contração da ferida começa a fazer com que suas margens se aproximem mais (KARUKONDA et al., 2000).

Com a ativação de macrófagos na ferida e com a elaboração de fatores de crescimento específicos, a matriz extracelular pode começar a ser substituída por 
um tecido conjuntivo mais forte e mais elástico. O principal componente de uma cicatriz de tecido conjuntivo maduro é o colágeno, assim, na ferida em processo de cura, fibroblastos produtores de colágeno são recrutados das margens da ferida por estímulo de fatores de crescimento de fibroblasto $\left.{ }_{(\mathrm{b}} \mathrm{FGF}\right)$ e TGF $\beta$, e são induzidos a sintetizar o colágeno, num processo coletivo conhecido como fibroplasia.

A fibroplasia tem início pela formação de tecido de granulação no espaço do ferimento. Esse tecido consiste de uma matriz frouxa de colágeno, fibronectina, e ácido hialurônico contendo macrófagos, fibroblastos, e vasos recém-formados e exsudativos, sendo o principal componente do tecido de granulação o grande número de vasos e os fibroblastos (WITTE; BARBUL, 1997).

A neovascularização (angiogênese) ocorre simultaneamente com o crescimento centrípeto dos fibroblastos a partir das margens da ferida. Vários fatores de crescimento e citocinas parecem estar envolvidos com a angiogênese, tais como FGF ( $\alpha$ e $\beta$ ), EGF, TGFa, PDGF, TGF $\beta$, VEGF, fatores de crescimento de células endoteliais derivados de plaquetas (PDEGF) e peptídeo regulador de afinidade da heparina (HARP) dentre outros (ARNOLD; WEST, 1991).

O acúmulo de colágeno final depende de uma disposição bem ordenada entre o aumento da síntese colagenosa e a diminuição da sua degradação, isto é, a harmonia entre a síntese do colágeno novo e a degradação do colágeno velho no local da lesão. Isso faz com que o tecido ricamente vascularizado se transforme em um tecido avascular e empalidecido (MITCHELLI, 2005).

\section{$\underline{\text { Remodelagem Tecidual }}$}

Ocorre a partir do $3^{\circ}$ dia com duração de meses ou anos. É durante essa fase que a cicatriz da ferida adquire sua máxima resistência, porém esse processo é lento, havendo necessidade de muitos meses e até mesmo anos. Ainda assim uma 
cicatriz cutânea completamente madura tem apenas $70 \%$ da resistência da pele normal.

Nessa fase os colágenos tornam-se as proteínas predominantes da cicatriz, a qual tem como principal característica à deposição do mesmo na ferida.

A atividade das colagenases é controlada pelas citocinas. As principais citocinas envolvidas nessa fase são TNF $\alpha$, IL-1 $\beta$, PDGF, TGF $\beta$ produzidas pelos fibroblastos, além das produzidas pelas células epiteliais como EGF e TGF $\beta$. Portanto, a remodelagem da síntese da matriz depende de uma interação entre os fibroblastos ativados e os fibroblastos que migram e proliferam.

À medida que ocorre a remodelagem da cicatriz, as fibras de colágeno ficam orientadas paralelamente às forças direcionais aplicadas sobre elas (KARUKONDA et al., 2000; WITTE; BARBUL, 1997).

\subsection{Morfometria das Úlceras}

A área de pesquisa que envolve o uso de ferramentas computacionais para auxílio ou acompanhamento do diagnóstico em lesões dermatológicas ainda é muito recente. A obtenção de imagem digitalizada das úlceras a partir de fotografias e scanner pode representar uma forma qualitativa de análise evolutiva das úlceras. Para uma análise quantitativa são necessários programas analisadores de imagem, porém, até recentemente isso se constituía em um obstáculo devido ao alto custo dos mesmos. O advento de câmeras digitais de preços acessíveis e de programas de análise de imagem disponíveis gratuitamente na rede facilitou o desenvolvimento de técnicas de análise morfométrica das úlceras de pele. 
A literatura descreve técnicas para análise de evolução das úlceras (GOIHMAN-YAHR, 1997; SHAI; MAIBACH, 2005):

Medida do máximo comprimento e largura: Duas folhas plásticas superpostas são colocadas sobre a úlcera para delineamento da área. A folha inferior, em contato com a úlcera, é descartada. A partir do desenho da úlcera na folha superior são traçados segmentos entre os pontos de maior distância longitudinal e transversal da área. Cada segmento é medido com auxílio de uma régua e os valores são utilizados para calcular a área superficial da úlcera através de uma aproximação por uma área retangular ou elíptica..

Medida de área com papel milimetrado: Utiliza-se um procedimento idêntico ao da técnica anteriormente descrita para o delineamento da área. Um papel milimetrado é colocado sob a folha plástica superior para a medida da área da úlcera através da contagem de milímetros quadrados.

\subsection{Tipos de Tratamento}

No tratamento convencional é de extrema importância à conscientização do paciente na assepsia, higiene e assiduidade na troca de bandagens e curativos, pois o tratamento convencional consiste na aplicação de curativos hidrocolóides, bandagens, faixas de compressão elástica, aplicação de agentes tópicos no local e medicação por via oral (FISCHER,1979). 
A bandagem oclusiva traz benefícios na redução da dor, desbridamento suave e proteção das infecções, e pode também estimular a formação de tecido de granulação (FALANGA et al., 1996).

Segundo Wiener et al. (1991), o tratamento por compressão é uma das importantes formas de terapia, indicado para reduzir o edema. No entanto, após 12 semanas, estudos controles não apresentam diferença entre curativos compressivos mais oclusão e curativos que utilizam apenas a compressão (CORDTS et al., 1992).

As bandagens elásticas, por fazerem parte do tratamento conservador de úlceras de origem venosa, são mais comumente usadas nos grupos controles e experimentais associadas a outros métodos para análise da eficácia dos tratamentos (ORMISTON et al., 1985).

As botas de Unna são bandagens semiflexíveis impregnadas com pasta de óxido de Zinco e protegem a úlcera de lesões externas e são trocadas semanalmente. Foi pesquisado em um trabalho o efeito do uso da bota de Unna em comparação com os efeitos dos curativos hidrocolóides, e os resultados foram significativos e favoráveis ao uso da Bota de Unna (RUBIN et al., 1990).

O desenvolvimento de um novo material biocompatível, a base de látex natural extraído da seringueira Havea brasiliensis vem sendo pesquisado com sucesso desde 1994. Esse material foi desenvolvido pelo setor de Neuroquímica da Faculdade de Medicina de Ribeirão Preto - Universidade de São Paulo/Brasil (SOARES et al., 2004)

A aplicação de agentes tópicos no local como curativos simples (vaselina, óleo mineral, sulfadiazina de prata e açúcar) e curativos mais complexos (hidrogel, filme transparente, carvão ativado, entre outros) tem vantagens, desvantagens, 
indicações e contra-indicações. Existem opções terapêuticas muito sofisticadas, que apresentam bons resultados, no entanto, são curativos cuja maior desvantagem é o alto custo, estando distante da realidade sócio econômica da grande maioria da população com úlcera venosa.

Considerando a importância da multiplicidade de opções para a realização do tratamento, optou-se pela aplicação do ultra-som de baixa intensidade.

Os parâmetros clínicos ideais da eletroterapia ainda não foram definidos. Estudos em animais e humanos proporcionaram evidências de que a estimulação elétrica promove a cicatrização das feridas de uma maneira segura e efetiva. Pode também contribuir diminuindo o edema, estimular os fatores de crescimento, aumentar a circulação sanguínea, induzir a migração celular, inibir bactérias mostrando assim os benefícios para estimular a cicatrização das feridas (DAYTON et al., 1989).

\subsection{O Ultra-som}

O som é uma forma de energia caracterizada pela vibração de moléculas de um meio. Propaga-se no ar, água, tecido, entre outros, através da transferência de energia vibracional de uma molécula para outra. Isto requer um meio deformável que pode ser gasoso, líquido ou sólido. Ainda que a molécula tenha deslocamento muito pequeno em relação à sua posição de repouso, o som é capaz de percorrer longas distâncias. O ouvido humano é capaz de perceber sons com freqüências de até $20 \mathrm{Khz}$. O ultra-som é a energia sonora com freqüência acima do limite de audição humana. A maioria das aplicações médicas utiliza freqüências entre 1 e 10 Mhz (HAAR, 1978). 
$\mathrm{Na}$ fisioterapia as variáveis do ultra-som são a freqüência do campo, freqüência de repetição e largura de pulso do sinal elétrico que excita o transdutor, a intensidade campo acústico e a duração do tratamento. A freqüência, geralmente, varia de 1 a $3 \mathrm{MHz}$ e a intensidade de 0,25 a $3 \mathrm{~W} / \mathrm{cm}^{2}$. Cada aplicação pode durar de 3 a 50 min (OKUNO et al., 1986).

No passado verificou-se que o ultra-som produzia aumento da temperatura em tecidos biológicos e entre 1930 e 1940 ele foi introduzido na prática médica como um recurso terapêutico usado particularmente para produzir calor em tecidos profundos. De 1940 até os dias atuais o ultra-som tem sido usado em áreas médicas e industriais, e novos efeitos e aplicações pesquisados (OKUNO et a.l, 1986)

\subsubsection{Bases Físicas do Ultra-som}

\subsubsection{Produção e Transmissão}

A técnica mais utilizada na construção de um dispositivo capaz de produzir ondas, o ultra-som (transdutor), baseia-se em um fenômeno estudado por Pierre e Marie Currie no final do século XIX denominado efeito piezoelétrico. Este pode ser observado em alguns materiais cristalinos, como o quartzo, que possui dipolos (regiões com cargas negativas e positivas) em suas moléculas. Em uma rede cristalina normal estes dipolos são aleatoriamente orientados e não podem migrar (HOOGLAND, 1986; KANH, 1991). Se o material é aquecido acima de uma temperatura denominada de temperatura de Curie, as moléculas podem mover-se livremente. Se um campo elétrico externo for aplicado ao material nessa 
temperatura, a região negativa das moléculas orienta-se na direção do pólo positivo daquele campo e a região positiva em direção ao pólo negativo. Por razões térmicas os alinhamentos das moléculas não são paralelos ao campo. Quando o material é resfriado abaixo da temperatura de Curie, enquanto o campo elétrico é mantido, a orientação das moléculas não é alterada.

Com o novo arranjo das moléculas o material adquire uma nova propriedade denominada piezoeletricidade. As faces do cristal são metalizadas e quando uma tensão é aplicada nessas faces às moléculas movimentam-se de maneira que as cargas positivas são atraídas pelo eletrodo negativo e cargas negativas pelo eletrodo positivo. O cristal expande-se e contrai-se produzindo uma vibração mecânica que é o ultra-som (OKUNO et al., 1986).

O ultra-som deve ser aplicado na pele através de um meio acoplador (géis, óleos e cremes) para evitar a reflexão da energia ultra-sônica na interface entre transdutor e a superfície de tratamento, eliminando assim o ar entre o transdutor e o tecido e transmitindo a energia ultra-sônica com eficiência (WILLIANS, 1987; DYSON, 1990).

\subsubsection{Características das Ondas Ultra-Sônicas}

Segundo Dyson (1990) e Haar (1978), o comprimento de onda $(\lambda)$ corresponde à distância entre regiões adjacentes de compressão ou de rarefação máxima, cujas partículas encontram-se em um mesmo estado de movimento, em um dado instante de tempo. A amplitude (A) do movimento oscilatório corresponde ao deslocamento máximo que uma partícula experimenta, a partir de sua posição de equilíbrio. O intervalo de tempo necessário para que uma partícula realize um ciclo 
completo de movimento é definido como período (T). A freqüência (f) corresponde ao número de vezes que uma partícula realiza um ciclo oscilatório por unidade de tempo. A freqüência é o inverso do período da onda. A velocidade $(C)$ de propagação da onda é à distância percorrida por uma partícula em uma unidade de tempo. Assim, a velocidade tem relação com o comprimento da onda segundo a equação $c=\lambda f$.

\subsubsection{Modos de Propagação:}

O modo de propagação da onda pode ser pulsado ou continuo. Dependendo da duração de perturbação provocada no meio, pode-se produzir um pulso ou onda única, um trem de ondas ou uma sucessão contínua de ondas (OKUNO et al., 1986).

No modo contínuo ocorre um depósito ininterrupto de energia sobre os tecidos irradiados. No modo pulsado, há interrupções freqüentes na propagação de energia, portanto há dois tipos de freqüência a serem consideradas: a freqüência da

onda (f) citada anteriormente e a freqüência de repetição de pulsos $\left(f_{r}\right)(K R E M K A U$, 1985).

\subsection{Interação do Ultra-som com os Tecidos}

\subsubsection{Impedância Acústica}

Impedância acústica $(Z)$ é a capacidade que o meio tem de se opor à vibração de suas partículas, frente à passagem de ondas ultra-sônicas. É 
considerada como constante, visto que, a velocidade do som no meio é basicamente constante dentro de uma larga faixa de freqüências (WILLIANS, 1987).

Quando as impedâncias acústicas dos dois meios são similares, quase toda a intensidade incidente é transmitida. Por esse motivo para se obter um bom acoplamento as aplicações de ultra-som são feitas na água ou colocando-se gel entre o transdutor e a pele para obter um bom acoplamento (OKUNO et al., 1986).

\subsubsection{Reflexão e Refração}

Quando uma onda sonora encontra uma interface entre dois meios diferentes, parte da energia é refletida e outra é refratada. A onda refletida retorna em sentido negativo através do meio incidente com a mesma velocidade de propagação, e a onda refratada continua em sentido positivo, mas sua velocidade é alterada em função das características do meio (OKUNO et al., 1986).

\subsubsection{Atenuação}

Segundo Haar et al. (1978), à medida que as ondas ultra-sônicas atravessam os tecidos parte da energia é refletida pelas estruturas que se encontram em sua trajetória (espalhamento) e parte da energia é absorvida pelo próprio meio, levando a um aquecimento local (absorção). A atenuação (perda da energia pelo feixe) ocorre devido a estes dois mecanismos, sendo que a absorção representa $60-80 \%$ da perda de energia.

$\mathrm{Na}$ absorção a energia sonora é convertida em calor, e essa é a propriedade usada em fisioterapia (OKUNO et al., 1986). 


\subsubsection{Campo Ultra-sônico:}

A região próxima ao transdutor é conhecida como campo próximo ou Zona de Fresnel, onde a distribuição de energia é altamente variável. Na região mais distante do transdutor, as ondas começam a divergir e a distribuição da energia torna-se mais regular; esta região é chamada de campo distante ou Zona de Fraunhoffer (DYSON, 1990).

\subsubsection{Efeitos Biológicos do Ultra-som}

O ultra-som quando atravessa um tecido, é absorvido e pode elevar a temperatura local. As mudanças biológicas que ocorrem no tecido devido à absorção seriam as mesmas caso a elevação de temperatura fosse provocada por qualquer outro agente. Quanto maior sua freqüência, maior a taxa de absorção do ultra-som (OKUNO et al., 1986).

A interação do ultra-som com os tecidos é à base das significantes mudanças fisiológicas, clínicas e terapêuticas, que estimulam a cicatrização tecidual e outras, potencialmente prejudiciais ao tecido (DYSON, 1990).

\subsubsection{Efeito Térmico}

Um estudo com 22 indivíduos saudáveis investigou as alterações de temperatura durante um período de 24 horas. A menor e a maior variação observada foi de $0,35{ }^{\circ} \mathrm{C}$ e $1^{\circ} \mathrm{C}$ o que permitiu concluir que elevações de 
temperaturas menores que $1^{\circ} \mathrm{C}$ não acarretam nenhum efeito biológico. (MELETTE et al., 1955)

Haar (1978) demonstrou que o ultra-som provoca aumento de temperatura $\left(0,86^{\circ} \mathrm{C}\right.$ por minuto) nos tecidos utilizando-se $1 \mathrm{~W} / \mathrm{cm}^{2}$ e $1 \mathrm{MHz}$ e a técnica estacionária. Isso inclui extensibilidade dos tecidos colágenos, diminuição de dor e espasmos musculares, apesar de nem todas as pesquisas apontarem nesse sentido.

A vantagem de se usar o ultra-som no aquecimento é que o terapeuta pode ter controle sobre a profundidade na qual ocorre o aquecimento (LEHMANN; GUY, 1972). Um dos efeitos fisiológicos do aquecimento induzido é o estimulo da cicatrização tecidual e o aumento a circulação sanguínea. Com o aumento na circulação a temperatura local eleva-se a $40-45^{\circ} \mathrm{C}$, valores aceitáveis por promoverem a vascularização tecidual. Porém se a temperatura exceder esse limite, pode causar necrose tecidual, fato que deve ser extremamente evitado (DYSON, 1990).

\subsubsection{Efeito não Térmico}

Algumas das mudanças fisiológicas induzidas pela terapia ultra-sônica que pode afetar o processo cicatricial são primariamente não-térmicas. Os efeitos físicos produzidos incluem, cavitação, fluxo acústico e formação de ondas estacionárias (DYSON, 1990).

Na cavitação o ultra-som pode provocar a formação de bolhas ou cavidades micrométricas nos líquidos, contendo gás em tecidos biológicos como sangue, linfa e em qualquer outro local do corpo. O campo ultra-sônico, pelas quais essas bolhas 
são expostas pode causar cavitação estável, isto é, uma vibração em resposta às mudanças cíclicas de pressão do ultra-som, ou cavitação transitória, que ocorre quando há alterações irregulares de pressão e altas temperaturas na região da bolha colapsada. A cavitação transitória produz dano local e causa formação de radicais livres. Em contraste, a cavitação estável pode ser induzida em tecidos moles in vivo com níveis baixos, e pode parcialmente ser responsável pela estimulação da reparação tecidual. Ao contrário do aquecimento, a cavitação ocorre mais facilmente em freqüências baixas do que em altas freqüências. Se a cavitação estável é requerida, então a baixa freqüência $(1 \mathrm{MHz})$ pode ser selecionada (DYSON, 1990).

\subsubsection{Força de Radiação}

Pode ocorrer um efeito biológico devido a ação da força de radiação, levando à deformidade tecidual, podendo deslocar, distorcer e/ou reorientar partículas intercelulares, ou mesmo células, com relação às suas configurações normais. As novas posições podem não ser biologicamente desfavoráveis e, como conseqüência, podem produzir efeitos danosos (OKUNO et al., 1986).

\subsection{Ultra-som em Regeneração Óssea}

A estimulação ultra-sônica da regeneração óssea é um tratamento nãoinvasivo de fraturas que utiliza ultra-som de baixa intensidade $\left(30 \mathrm{~mW} / \mathrm{cm}^{2}\right)$. Duarte (1983), em estudos com animais, foi o primeiro a demonstrar que a terapia de pulsos por ultra-som de baixa intensidade poderia afetar a consolidação de fraturas, 
provocando um aumento significativo do calo ósseo. A evidência de que o ultrasom pulsado de baixa intensidade não apenas aumenta a quantidade de calo, como também aumenta significativamente a resistência mecânica e rigidez do calo, foi demonstrada por (PILLA et al., 1991; WANG et al., 1994). Wang et al. (1994) demonstrou que o tratamento com ultra-som de baixa intensidade aumenta a resistência em um modelo de fratura femoral em ratos.

Estudos investigaram o mecanismo de ação do ultra-som de baixa intensidade (RYABY et al., 1989, 1990, 1991,1992; SATO et al. , 1999; KOKUBO et al., 1999; ITO et al., 2000). Rawool et al. (1998) demonstraram que o ultra-som de baixa intensidade aumenta o fluxo sanguíneo no sítio da fratura, e conseqüentemente contribui com a síntese de substâncias importantes como citocinas e fatores de crescimento para o processo de consolidação.

Azuma et al. (2001) investigaram quatro diferentes períodos de tratamento de fraturas com ultra-som de baixa intensidade e demonstraram que a consolidação foi acelerada em todos os grupos de estudo, independentemente do período ou duração do tratamento.

O uso clínico da terapia de ultra-som pulsado de baixa intensidade foi relatado pela primeira vez por Xavier e Duarte (1983). Diversos estudos clínicos comprovaram a eficiência dessa terapia no tratamento de fraturas recentes, retardos consolidação ou não-união (CHOFFIE et al., 1994; HECKMAN et al., 1994; DUARTE et al., 1996; STRAUSS et al., 1996; KRISTIANSEN et al., 1997; MAYR et al., 1997; MEANI E ROMANO, 1997; ROMANO et al., 1999; GEBAUER et al., 2000; WARDEN et al., 2000; COOK et. al., 2001; YANG et al., 2005; TANG et al., 2006). 
Hadjiargyrou et al. (1998) revisaram os estudos em animais e clínicos que utilizaram ultra-som de baixa intensidade na consolidação de fraturas e incluíram os estudos in-vivo e in vitro, que investigaram os mecanismos biológicos afetados pelo estímulo ultra-sônico.

Rubin et al. (2000) revisaram dados substanciais de ciência básica que demonstram uma influência positiva nos três estágios do processo de consolidação (inflamação, reparo e remodelamento), devido ao aumento da atividade angiogênica, condrogênica e osteogênica.

\subsection{Efeitos do Ultra-som em Tecido Mole}

As pesquisas realizadas com ultra-som de alta e baixa intensidades foram primeiramente investigadas em tecidos ósseos e posteriormente houve um interesse em investigar sua utilização em tecido epitelial.

O uso do ultra-som em cicatrização de feridas vem sendo pesquisado por Dyson desde 1976. Dyson et al. (1976) utilizaram um aparelho de ultra-som com intensidade de $1 \mathrm{~W} / \mathrm{cm}^{2}$ e freqüência de $3 \mathrm{MHz}$, em uma amostra de 12 úlceras de origem venosa, com aplicações de 5 a 10 minutos, 3 vezes por semana, durante 4 semanas, sendo que a própria amostra serviu como controle nas 4 semanas seguintes. Obtiveram como resultado uma redução de $25,2 \%$ superior ao grupo controle. Posteriormente em um estudo realizado por Dyson e Suckling em 1978 foram utilizados 25 casos de úlcera venosa divididos em grupo tratado e grupo placebo (irradiação simulada). Utilizando um ultra-som de $1 \mathrm{w} / \mathrm{cm}^{2}$ e $3 \mathrm{MHz}$, verificaram redução significativa nas medidas das áreas das úlceras após o estímulo em relação ao placebo. Após alguns anos Dyson (1987) começou a 
realizar uma análise histopatológica em seus experimentos e observou um aumento de fibroblastos e degranulação de macrófagos em tecidos estimulados com ultrasom. Em 1989 Young e Dyson realizaram um trabalho para verificar a ocorrência de angiogênese na injúria, onde 36 ratas wistar foram divididas em grupo tratado e grupo placebo (irradiação simulada). Observaram que ultra-som na freqüência de $0,75 \mathrm{MHz}$ e intensidade de $0,1 \mathrm{w} / \mathrm{cm}^{2}$ em lesões cutâneas de ratos pode estimular 0 crescimento de capilares com 5 dias de tratamento. Os resultados obtidos mostraram que a terapia pelo ultra-som pode ser útil, acelerando a proliferação inflamatória e assim fazer com que a cicatrização ocorra mais cedo. Young e Dyson (1990) realizaram um experimento in vitro com cultura celular de macrófagos, utilizando 2 grupos experimentais. Os Grupo 1 e 2 foram observados 30 min 12 horas, respectivamente, após a irradiação por ultra-som. Verificaram aumento de fibroblastos após a estimulação por ultra-som de $0,75 \mathrm{MHz}$ no grupo 1 , e de 0,75 e 3 $\mathrm{MHz}$ no grupo 2. A intensidade do ultra-som em ambos os grupos foi de $0,5 \mathrm{w} / \mathrm{cm}^{2}$.

Lundenberg et al. (1990) realizaram um estudo experimental com ultra-som pulsado em 44 pacientes com úlceras venosas, divididos em dois grupos. Ambos os grupos foram tratados por 12 semanas ( 3 meses), sendo que no $1^{\circ}$ mês o tratamento era de 3 vezes semanais, no $2^{\circ}, 2$ vezes semanais e no $3^{\circ}, 1$ vez semanal. O primeiro grupo foi estimulado com ultra-som pulsado de $1 \mathrm{MHz}$ e intensidade de $0,5 \mathrm{w} / \mathrm{cm}^{2}$ e o segundo grupo foi definido como controle (US placebo). Ambos os grupos usavam gases impregnadas de pasta e bandagem elástica. Os autores não encontraram diferenças significativas na proporção de cicatrização entre o grupo estimulado e o placebo. Alguns anos depois outros autores realizaram esta mesma investigação. Swist-Chmielewska et al. (2002) investigaram o uso do ultra-som de $1 \mathrm{w} / \mathrm{cm}^{2}$ e o de $0,5 \mathrm{w} / \mathrm{cm}^{2}$, comparando com o 
grupo controle, o qual era tratado com métodos tradicionais. Tinham como objetivo verificar qual era a técnica mais eficaz na redução da área, volume e aumento de granulação. Observaram que o ultra-som de $0,5 \mathrm{w} / \mathrm{cm}^{2}$ mostrou melhores resultados na diminuição da área e do volume de úlceras venosas, levando-as a uma cicatrização mais rápida. Porém, em termos de desenvolvimento da granulação, não houve diferença entre os grupos. Em outro estudo Franek et al. (2004) compararam o ultra-som de $0,5 \mathrm{w} / \mathrm{cm}^{2}$ e de $1 \mathrm{w} / \mathrm{cm}^{2}$ com o tratamento convencional, em 65 pacientes portadores de úlcera venosa, com o objetivo de verificar qual o mais eficaz. Dividiram aleatoriamente a amostra em 3 grupos, sendo: a) grupo A: aplicação do ultra-som e 1 w/cm² e $1 \mathrm{MHz}$; b) grupo B: aplicação do ultra-som 0,5 w/cm² e $1 \mathrm{MHz}$; c) grupo $\mathrm{C}$ (grupo controle) com tratamento farmacológico. Observaram que o grupo tratado com ultra-som de $0,5 \mathrm{w} / \mathrm{cm}^{2}$ e $1 \mathrm{MHz}$ foi o que apresentou maior redução da área e do volume total da úlcera.

Peschen et al. (1997) examinaram o efeito do ultra-som de baixa freqüência em 24 pacientes portadores de úlceras venosas crônicas. Os pacientes foram aleatoriamente colocados em grupos paralelos. O grupo tratado consistia na aplicação tópica de curativos e hidrocolóides (terapia convencional) e tratamento adicional do ultra-som. O grupo placebo foi tratado somente com a terapia convencional. Ambos foram tratados por 12 semanas. O grupo tratado consistia na aplicação do ultra-som contínuo de $30 \mathrm{KHz}\left(100 \mathrm{mw} / \mathrm{cm}^{2}\right)$, com imersão da perna em uma banheira contendo água com temperatura de $32^{\circ}$ a $34^{\circ} \mathrm{C}$ por 10 minutos, 3 vezes por semana. Os resultados mostraram redução das medidas diárias das úlceras tratadas com ultra-som, e que a aplicação do ultra-som de baixa intensidade e baixa freqüência é uma opção de tratamento de grande ajuda no tratamento das 
úlceras venosas crônicas, principalmente quando as mesmas não apresentam boas respostas ao tratamento convencional.

Hilário (1993) e Anastácio (2000) investigaram os efeitos do tratamento de úlceras tróficas pelo ultra-som de baixa intensidade $\left(25 \mathrm{mw} / \mathrm{cm}^{2}\right)$. Elas classificaram as úlceras em pequena, média e grande e utilizaram um tempo de aplicação de 20 ou 30 minutos, sendo o ultra-som aplicado de maneira estacionária ao longo da borda da ferida, 3 vezes por semana. Em uma análise macroscópica Hilário (1993) verificou que a porcentagem média de úlcera cicatrizada em doze semanas de tratamento foi de $66 \%$. Anastácio verificou em uma análise histopatológica de alguns casos a neoformação de vasos e o aumento de fibroblastos nas úlceras em doze semanas de tratamento. Na análise macroscópica verificou a redução das áreas das úlceras. Tanto para Hilário (1993) quanto para Anastácio (2000) o ultrasom de baixa intensidade agiu significativamente na redução das úlceras, acelerando o processo de cicatrização das úlceras.

Santana (2003) usou o ultra-som de baixa intensidade $\left(30 \mathrm{~mW} / \mathrm{cm}^{2}\right) \mathrm{com}$ uma freqüência de $1,5 \mathrm{MHz}$ em úlceras de pele de 2 pacientes. $O$ tratamento foi realizado 5 vezes por semana durante 20 minutos diários. A forma de aplicação foi não estacionária, usando o ultra-som com movimento circular em volta da ferida. A análise foi feita através de fotos das lesões por um software analisador de imagens, constatando-se uma diminuição de até $5,2 \%$ da área da ferida.

Weichenthal et al. (1997) estudaram 38 pacientes portadores de úlcera venosa por mais de 3 meses e os pacientes foram divididos aleatoriamente em 2 grupos. Um grupo foi tratado por ultra-som de baixa intensidade $\left(100 \mathrm{mw} / \mathrm{cm}^{2}\right)$, de $30 \mathrm{KHz}$, por 10 minutos, com o membro do paciente imerso em água, e o transdutor a $5 \mathrm{~cm}$ de distância do local da úlcera. Com o outro foi realizado tratamento 
convencional, com aplicações de agentes fibrinolíticos, antibióticos e antissépticos. Ambos os grupos eram tratados 3 vezes por semana por 2 meses. Fotografias coloridas foram tiradas uma vez por semana e as imagens foram mensuradas por um software de medidas. Apesar de não haver diferença estatisticamente significante, pôde-se observar uma redução maior no grupo tratado por ultra-som com 3 e 8 semanas de tratamento. Na $8^{a}$ semana a diferença era de $87 \%$ de redução no grupo tratado com ultra-som, versus $57 \%$ do grupo com tratamento convencional.

Hsu e Huang em 2004 em estudo in-vitro utilizaram ultra-som de $1 \mathrm{MHz}$, pulsado (1:4) nas intensidades de $0,5 \mathrm{~W} / \mathrm{cm}^{2}, 1,0 \mathrm{~W} / \mathrm{cm}^{2}, 1,6 \mathrm{~W} / \mathrm{cm}^{2}$ e $2,0 \mathrm{~W} / \mathrm{cm}^{2}$, durante 10 minutos por dia, visando à estimulação de células endoteliais. Verificaram que o ultra-som $\left(1,6\right.$ e 2,0 w/ $\left.\mathrm{cm}^{2}\right)$ após 6 dias de tratamento ressaltou o óxido nítrico (NO) e $\mathrm{Ca}^{2+}$ liberados da células endoteliais, mas não promoveu crescimento celular. Concluíram que a estimulação por ultra-som muda a morfologia e orientação celular, e aumenta a secreção da matriz extracelular de células endoteliais.

Reher et al. (1998) estudaram o efeito do ultra-som in vitro em células de monócitos, fibroblastos e osteoblastos. Verificaram uma estimulação do IL-1 $\beta$, notado em todos os tipos celulares, com níveis mais altos nos monócitos estimulados com $45 \mathrm{KHz}$ e nos osteoblastos estimulados com $1 \mathrm{MHz}$. O IL-8 teve aumento apenas nos osteoblastos e o nível mais alto foi notado com o ultra-som de $45 \mathrm{KHz}$. O FGF $\beta$, também teve aumento apenas nos osteoblastos, porém a produção esteve significativamente elevada com ambos os mecanismos de ultrasom. O VEGF alcançou o maior número de produção sendo observado nos 3 tipos de células, e por ambos mecanismos de ultra-som. Observaram que o IL-8 e FGF $\beta$ 
são significativamente estimulados nos osteoblastos, e o VEGF em todos os tipos de células estudadas. Ambos os mecanismos de ultra-som produziram resultados significantes com intensidade entre 15 e $30 \mathrm{mw} / \mathrm{cm}^{2}$ e $45 \mathrm{KHz}$ e com intensidades de $0,1 \mathrm{~W} / \mathrm{cm}^{2}$ e $0,4 \mathrm{~W} / \mathrm{cm}^{2}$ e $1 \mathrm{MHz}$.

\subsection{Sulfadiazina de prata}

A sulfadiazina de prata é composta de nitrato de prata e sulfadiazina de sódio e encontra-se no mercado na forma de creme branco a $1 \%$. Ela possui uma atividade antimicrobiana bastante ampla. É bactericida para uma grande variedade de bactéria Gram-positivas e Gram-negativas, bem como algumas espécies de fungos (Pseudomonas aeruginosa, Staphylococcus aureus, algumas espécie de Proteus, Klebsiella, Enterobacter e Candida albicans (WARD; SAFLLE, 1995). A atividade antimicrobiana da sulfadiazina de prata é mediada pela reação do íon prata com o DNA microbiano, o que impede a replicação bacteriana. Além disto, age sobre a membrana e parede celular, promovendo o enfraquecimento destas e segundo alguns estudo tem capacidade de inibir o DNA (DRUG INFORMATION; 2002).

A sulfadiazina de prata é indicada na prevenção e tratamento de feridas como: queimaduras, úlceras venosas, úlceras de decúbito e feridas cirúrgicas infectadas. Deve ser aplicada 2 vezes ao dia, seguindo sempre orientação médica (DRUG INFORMATION; 2002). 


\subsubsection{Sulfadiazina de prata $1 \%$ no Tratamento das Úlceras de Perna}

Primeiramente a Sulfadiazina de prata $1 \%$ era utilizada no tratamento de queimaduras, sendo recomendada em queimaduras de segundo e terceiro graus. (WARD; SAFLLE, 1995). Posteriormente ela começou a ser usada na terapia tópica de úlceras venosas. Bishop et al. em 1992 realizaram um estudo prospectivo duplocego em pacientes com úlceras venosas com níveis bacterianos comparáveis e demonstraram que a Sulfadiazina de prata $1 \%$ reduziu de forma estatisticamente significativamente o tamanho das úlceras $(44 \%$ em relação a $22,5 \%$ dos que utilizaram placebo). Tais autores associaram a eficácia desta droga a um favorecimento da replicação de queratinócitos e a propriedades antiinflamatórias da substância. 
3. Metodologia 


\subsection{Seleção dos Pacientes}

Foram selecionados pacientes do "Ambulatório da Dermatologia de Úlceras Neurovasculares" (ADUN) do HCFMRP - USP e do "Centro Saúde Escola" (CSE) do HCFMRP - USP. Após a seleção, os pacientes foram esclarecidos sobre as características do estudo e assinaram o termo de consentimento (ANEXO A).

- Critérios de Inclusão

Pacientes com úlcera de perna que:

- Apresentavam sinais clínicos clássicos de insuficiência venosa como varicosidades, edema, eczema, lipodermatoesclerose, e elefantíase.

- Apresentavam úlceras de qualquer tamanho.

- Possuíam HAS (Hipertensão Arterial Sistêmica) controlada, ou seja, PAD (Pressão Arterial Diastólica) < $95 \mathrm{mmHg}$.

- Critérios de Exclusão

Pacientes que não apresentavam os critérios de inclusão e/ou apresentavam:

- Transtornos psíquicos intelectuais.

- Co-morbidades como neoplasias, diabetes mellitus, entre outras.

- HAS descontrolada.

- Condições precárias de higiene pessoal.

- Úlceras Infectadas.

- Úlceras agudas 


\subsection{Padronização dos Grupos}

Os pacientes selecionados foram distribuídos aleatoriamente, por ordem de chegada, e alternadamente, independente de sexo, idade, cor e religião, nos grupos experimentais.

\subsection{Técnica de Tratamento}

Grupo 1 ( $n=7$ úlceras): neste grupo, os pacientes tiveram suas úlceras tratadas com curativos diários à base de creme sulfadiazina de prata1\% (SDZ) e cobertura com gazes e ataduras, realizados no domicílio.

Grupo 2 ( $n=9$ úlceras): os pacientes tiveram suas úlceras tratadas com ultrasom de baixa intensidade (US) em dias alternados (segundas, quartas e sextasfeiras). O tempo diário de tratamento dependia da extensão da úlcera. O tratamento foi feito na periferia da lesão ficando o transdutor ultra-sônico estacionário. A distância entre dois locais adjacentes de tratamento foi de $2 \mathrm{~cm}$. Em cada local o tempo de tratamento foi de 3 minutos. Toda a periferia da lesão foi tratada e o tempo total de tratamento nunca foi inferior a 20 minutos.

Em ambos os grupos as úlceras foram tratadas por 90 dias.

A figura 3.1 mostra uma das úlceras tratada com ultra-som de baixa intensidade. 


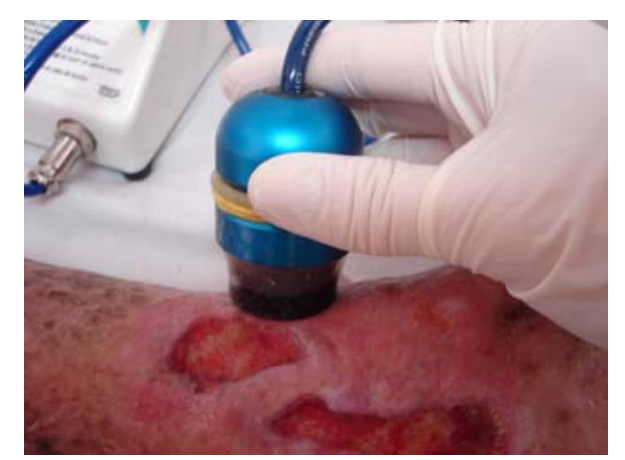

Figura 3.1 - Tratamento de úlcera por ultra-som

\subsubsection{Transdutor Ultra-Sônico}

Foi utilizado um aparelho de ultra-som com as seguintes características (figura 3.2): intensidade de $30 \mathrm{~mW} / \mathrm{cm}^{2}$, modo pulsado com burst de $1,5 \mathrm{MHz}$; largura de pulso de $200 \mu$ s e freqüência de repetição de pulso de $1 \mathrm{KHz}$. Estes parâmetros foram utilizados em estudos anteriores envolvendo úlceras, queimadura e tendão.

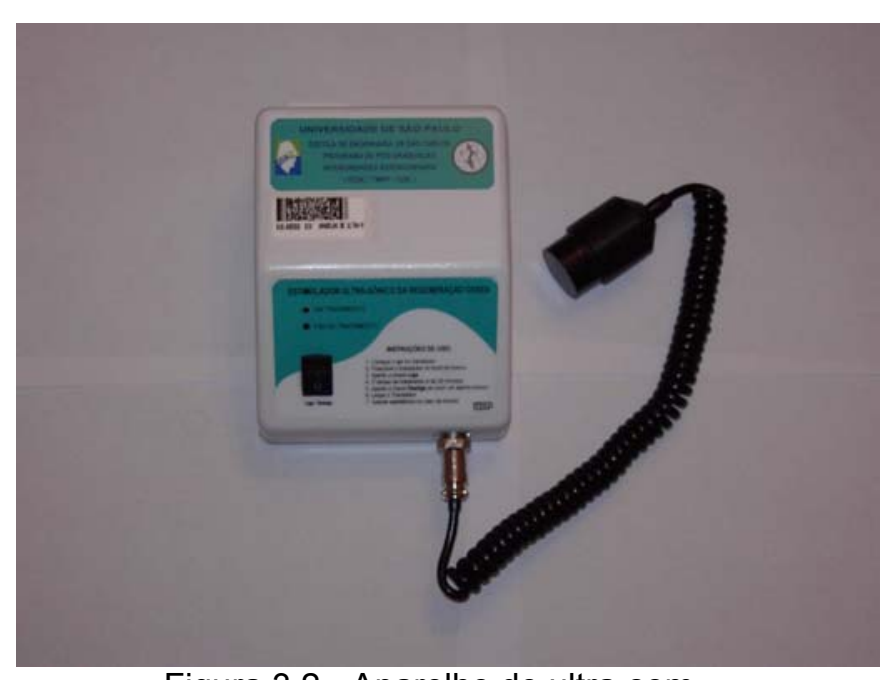

Figura 3.2 - Aparelho de ultra-som

O transdutor foi submetido à anti-sepsia antes e após cada sessão com gases embebidas em álcool $70 \%$. Para uma melhor prevenção séptica foi utilizada uma película de látex (condom) no cabeçote do ultra-som a cada sessão. Uma camada de gel foi utilizada entre a superfície do transdutor e a superfície interna da película bem como entre a superfície externa da película e a borda da lesão. $O$ cálculo da atenuação causada pela película é pequeno devido à sua espessura. 
Esse resultado teórico foi comprovado experimentalmente através da medida da intensidade acústica, com e sem a presença da película de látex, em uma "Balança de Radiação Acústica". Dosimetrias periódicas foram realizadas no laboratório do "Programa de Pós-Graduação Interunidades em Bioengenharia - USP” (São Carlos, SP) para monitoramento da energia transmitida.

Os cálculos a seguir demonstram que o uso do preservativo de látex entre a superfície do transdutor ultra-sônico e a periferia das úlceras causa pouca atenuação da energia ultra-sônica

Na figura 3.3 estão esquematizados três meios com impedâncias acústicas $r_{1}, r_{2}$ e $r_{3}$, respectivamente. Os meios 1 e 3 representam o gel ultra-sônico e o meio 2 a camada de látex de pequena espessura (preservativo). A constante $k=w / c=2 \pi f / c$ é denominada número de onda, sendo c a velocidade do ultra-som no meio.

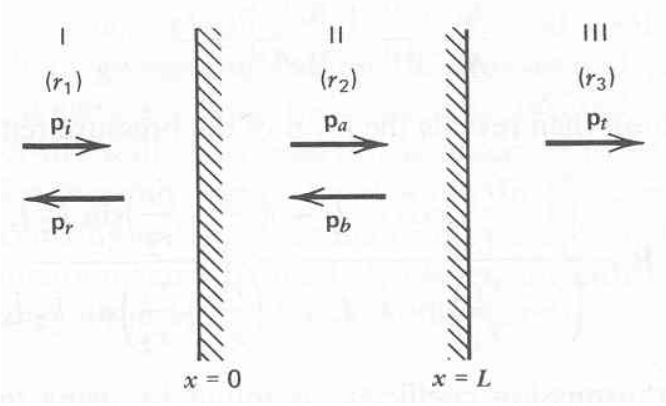

Figura 3.3 - Representação esquemática dos meios com impedância acústica (Kinsler L.E. et al, Fundamentals of Acoustics, pg. 127, 1982)

A porcentagem de transmissão da energia ultra-sônica propagando-se do meio 1 em direção ao meio 3 é determinada pela equação abaixo (Kinsler, 1982):

$$
T_{\text {total }}=\frac{4}{2+\frac{r_{3}}{r_{1}}+\frac{r_{1}}{r_{3}} \cos ^{2} k_{2} L+\frac{r_{2}^{2}}{r_{1} r_{3}}+\frac{r_{1} r_{3}}{r_{2}^{2}} \operatorname{sen}^{2} k_{2} L}
$$

Considerando-se que o meio 1 e 3 são iguais obtem-se: 


$$
T_{\text {total }}=\frac{4}{2+2 \cos ^{2} k_{2} L+\frac{r_{2}^{2}}{r_{1}{ }^{2}}+\frac{r_{1}^{2}}{r_{2}{ }^{2}} \operatorname{sen}^{2} k_{2} L}
$$

No entanto $\frac{r_{2}^{2}}{r_{1}^{2}}+\frac{r_{1}^{2}}{r_{2}^{2}}=2+\frac{r_{2}}{r_{1}} \frac{r_{1}}{r_{2}}$ e a equação (3.1) pode ser reescrita:

$$
\begin{gathered}
T_{\text {total }}=\frac{4}{2+2 \cos ^{2} k_{2} L+2+\frac{r_{2}}{r_{1}}{\frac{r_{1}}{r_{2}}}^{2} \operatorname{sen}^{2} k_{2} L}= \\
T_{\text {total }}=\frac{4}{2+2 \cos ^{2} k_{2} L+\frac{r_{2}}{r_{1}}{\frac{r_{1}}{r_{2}}}^{2} \operatorname{sen}^{2} k_{2} L+2 \operatorname{sen}^{2} k_{2} L} \\
T_{\text {total }}=\frac{r_{2}^{r_{1}} \frac{r_{1}}{r_{2}} \operatorname{sen}^{2} k_{2} L}{4}
\end{gathered}
$$

Na equação 3.2 se $L \rightarrow 0$, isto é, se a espessura do preservativo for pequena, então $\operatorname{sen}^{2} \mathrm{~kL} \rightarrow 0$ e, portanto, $\mathrm{T}_{\text {total }} \rightarrow 1$. Isto pode ser comprovado substituindo-se na equação (3.2) os valores de $r_{1}=r_{\text {látex }}=1,74$ Mrayls, $\quad r_{2}=r_{\text {gel }}=r_{\text {água }}=1,48$ Mrayls, $K_{2}=2 \pi f / C_{2}=6,08 \times 10^{3}$ e admitindo-se que senK $K_{2} L=0,1$ (isto é, $K_{2} L=6$ e $L \approx 1 \mathrm{~mm}$ ):

$$
T_{\text {total }=} \frac{1}{1+\frac{1}{4} \frac{1,74}{1,48} \frac{1,48}{1,74}^{2}{ }_{0,01}}=0,9997
$$

Portanto, a transmissão da energia ultra-sônica não é afetada pela espessura da película de látex (preservativo) se a espessura da mesma for pequena. 


\subsection{Assepsia da Úlcera}

Antes de começar o tratamento, as feridas foram lavadas cuidadosamente com soro fisiológico $0,9 \%$ e gazes. Após a limpeza, o leito da úlcera foi mantido seco com auxílio das gazes.

\subsection{Avaliação Clínica}

Os pacientes foram submetidos a um protocolo de avaliação médico-clínica sob responsabilidade do Prof $^{\circ}$. Dr $^{\circ}$. Marco Andrey Cipriani Frade (ANEXO B) constando de:

- Identificação

- Doenças Associadas

- Medicamentos em uso

- Exame da ferida (medidas, fundo, borda, características teciduais, recidivas ou não).

- Pulso e Artérias

\subsection{Avaliação Clínico Fotográfica}

A documentação fotográfica das úlceras nos 2 grupos de estudo foi obtida a cada 15 dias por um período máximo de 90 dias. Essas imagens foram analisadas pelo software de análise de imagens Image $J^{\circledR}$ para quantificação da área da úlcera e avaliação das características dos tecidos. 
A análise de imagem foi realizada no "Laboratório de Biologia Celular" da Faculdade de Medicina de Ribeirão Preto - USP com o auxílio do Prof. Dr. João Kajiwara.

\subsubsection{Captura da Imagem}

As figuras $3.4 \mathrm{a}$ e $3.4 \mathrm{~b}$ mostram um dispositivo projetado com o objetivo de padronizar a captura das imagens das úlceras contendo as seguintes características: a) suporte de alumínio na forma de arco para uma máquina fotográfica digital (SonyDSC P93). O suporte tem $80 \mathrm{~cm}$ de altura, diâmetro de $70 \mathrm{~cm}$ e uma base de acrílico de $50 \mathrm{~cm} \times 70 \mathrm{~cm}$; b) iluminação com uma lâmpada tipo farol de milha apontada para o teto com o intuito de diminuir o reflexo. A lâmpada foi acoplada ao suporte de alumínio e constituiu a única iluminação do ambiente. As demais lâmpadas foram desligadas e a iluminação natural bloqueada com o uso de cortinas;

c) Roldanas permitem o movimento da máquina fotográfica e da lâmpada; d) Uso de etiquetas auto colantes, com marcação em centímetros, para uso na borda da úlcera, com o intuito de ajustar as angulações da úlcera durante a análise de imagem. As etiquetas também foram utilizadas como régua durante o procedimento de quantificação da imagem da úlcera, utilizando-as para padronização da escala. e) Uso de papel tamanho ofício abaixo do membro do paciente para delimitar a borda do mesmo, o qual foi usado sempre que a úlcera foi fotografada com o intuito de manter o membro sempre na mesma posição. 


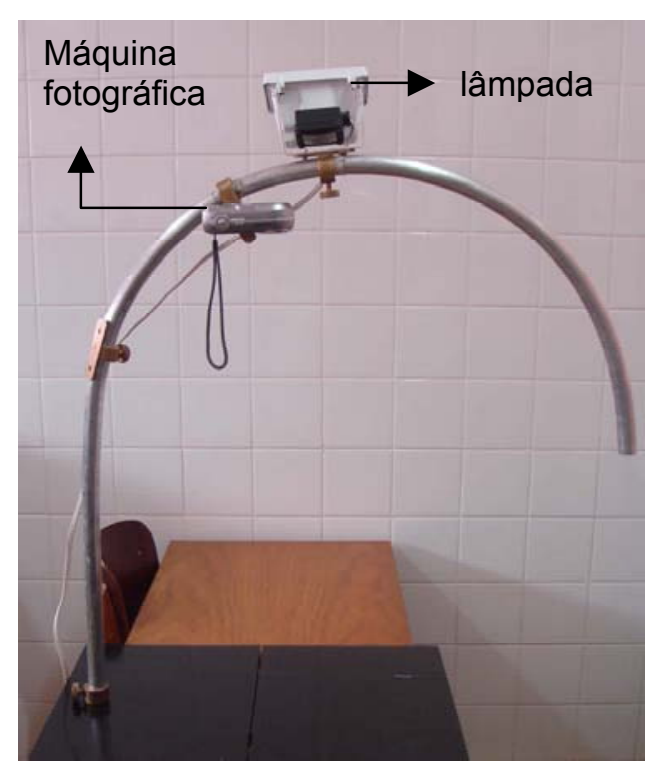

Figura 3.4a - Aparelho para câmera fotográfica

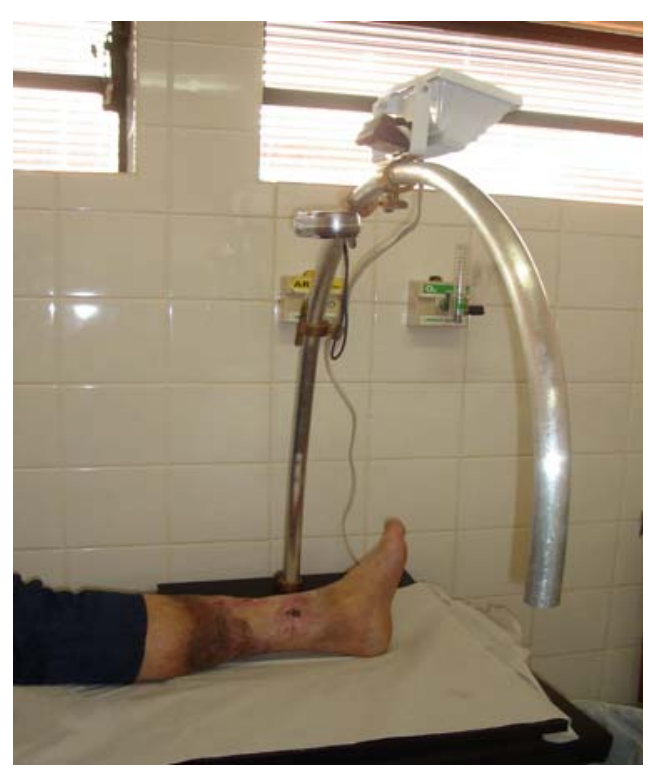

Figura 3.4b - Ilustração da utilização do aparelho

A figura 3.5 mostra os materiais usados para a padronização das fotos.

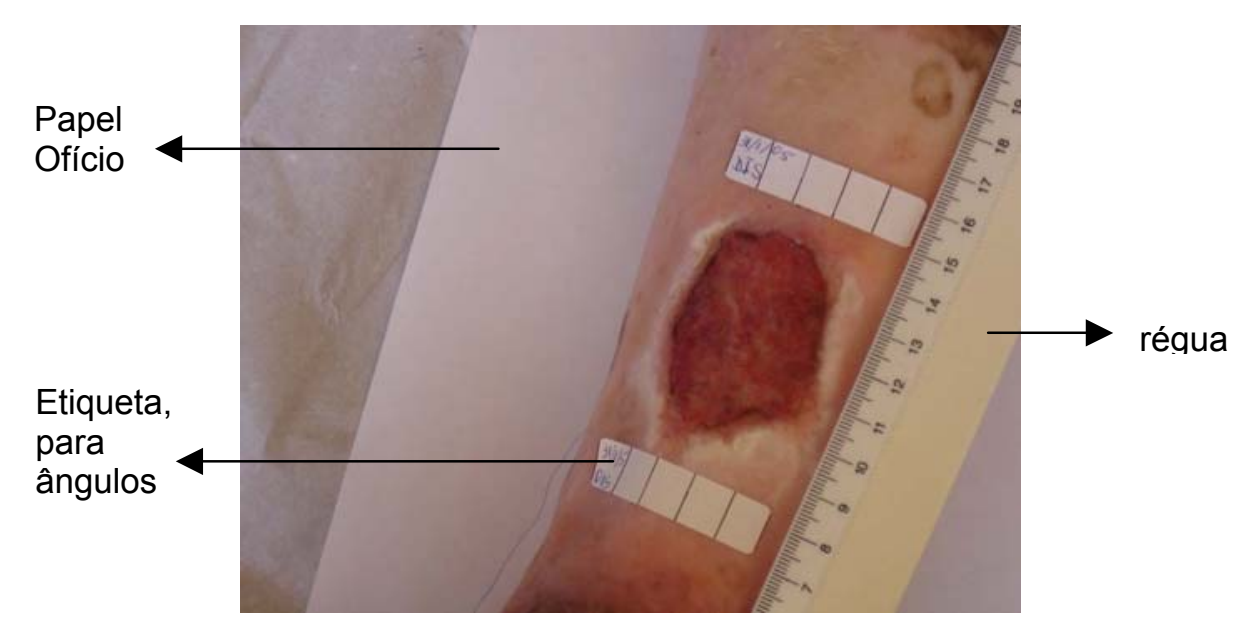

Figura 3.5 - Foto padronizada para análise de imagem

\subsection{Detalhamento da Análise de Imagem}

O analisador de imagem foi utilizado no monitoramento das úlceras e na análise da imunohistoquímica, segundo o procedimento descrito a seguir: 
Etapa 1: Fotografia das úlceras com uma câmera digital Sony DSC P93, com resolução de 5.0 megapixels, foram transferidas para o disco rígido de um microcomputador (Pentium IV, $2.2 \mathrm{GHz}, 256$ Mbytes de memória RAM) para a realização dos procedimentos de quantificação. As imagens da imunohistoquímica foram registradas por uma câmera digital Nikon E995 acoplada a um microscópio Zeiss com uma objetiva de 40x e transferidas para o mesmo microcomputador.

\section{Características do software de análise de imagens}

O ImageJ ${ }^{\circledR}$, desenvolvido por Wayne Rasband do Research Services Branch, National Institute of Mental Health (Bethesda, Maryland, EUA), é um software processador e analisador de imagens em Java de domínio público, inspirado no NIH ImageJ para o Apple Macintosh (figura 3.6). Dessa forma pode ser executado em diversos ambientes operacionais desde que os mesmos possuam uma máquina virtual Java apropriada. Além disso, o repertório de funções deste software pode ser expandido através de diversos plugins prontos, disponíveis na Internet, ou desenvolvendo-se novos plugins.

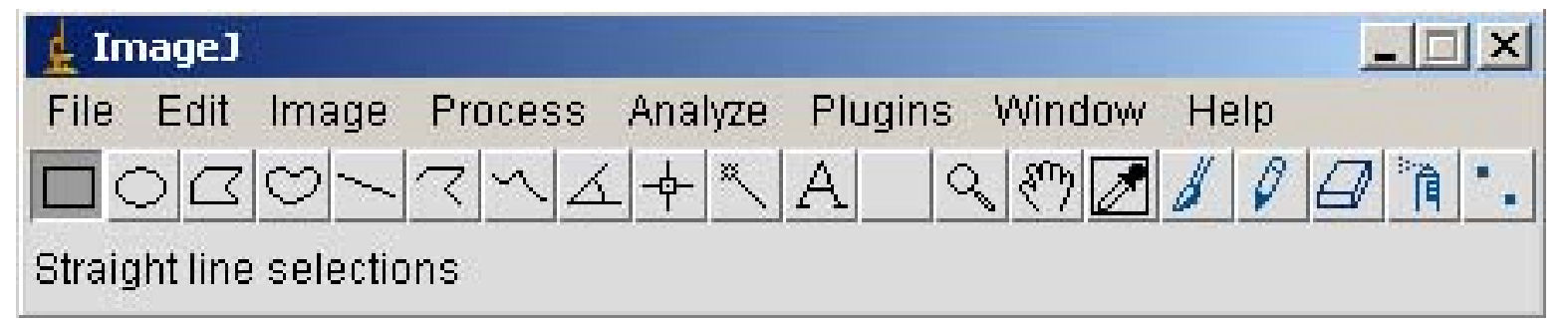

Figura 3.6 - Programa Image ${ }^{\circledR}$

Etapa 2: Seleção da imagem desejada para quantificação da área da úlcera e dos seus respectivos tecidos ou para a quantificação das áreas da cor cobre, anteriormente citadas.

Foi selecionado o plugin polygon e rectangular (figura 3.7a e 3.7b) para segmentação das áreas das imagens das úlceras ou da imunohistoquímica, 
respectivamente. Este procedimento é manual e utiliza o mouse (figura 3.8 e 3.9).

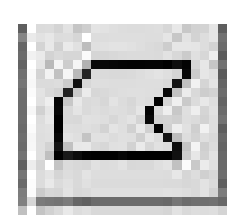

Figura 3.7a - Ícone do Plugin polygon

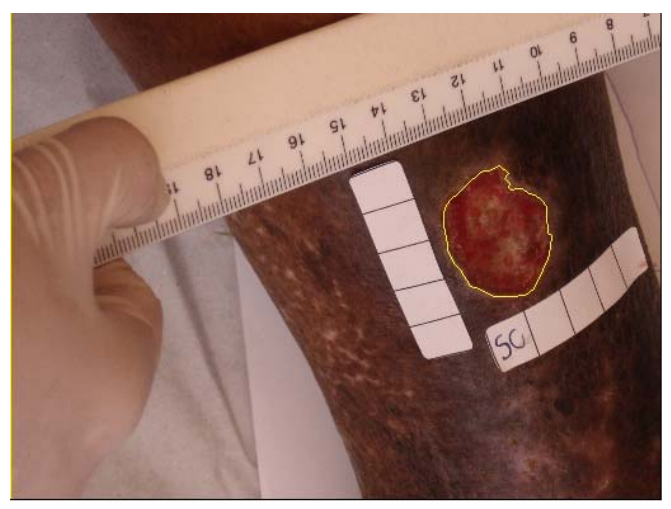

Fiqura 3.8 - Úlcera seamentada

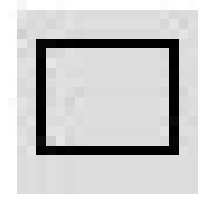

Figura 3.7b - Ícone do Plugin rectangular

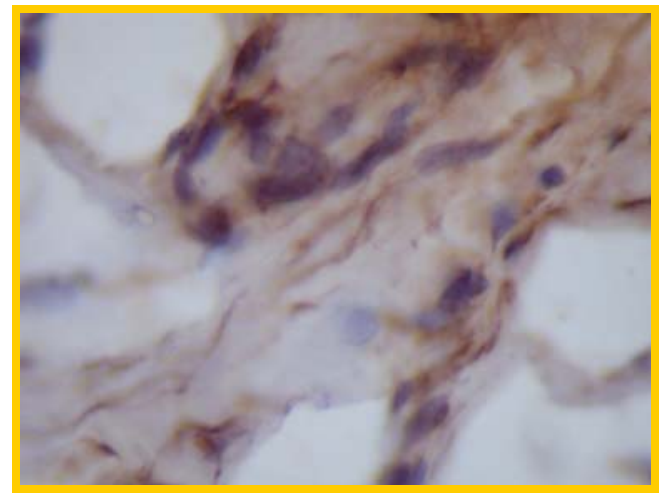

Figura 3.9 - Imunohistoquímica segmentada

Etapa 3: Segmentação da área da úlcera (figura 3.8) e cálculo da área através do comando $<$ Ctrl $M>$ do teclado, após ajuste apropriado da escala. As escalas das imagens foram calibradas utilizando etiquetas auto-colantes.

Etapa 4: Seleção das áreas de granulação (área vermelha) e de fibrina (área amarela) na imagem da úlcera. Foram utilizadas as características de matiz, brilho e saturação da luz refletida e não somente o brilho, como é mais usual. A seleção é realizada pelo plugin threshold_colour bastando definir o intervalo da cor de interesse (figura $3.10 \mathrm{a}$ e $3.10 \mathrm{~b}$ ). O software torna brancas as áreas de interesse e pretas as demais áreas. A figura 3.11 mostra à imagem real de uma úlcera e a figura 3.12 mostra duas imagens sendo uma com seleção de área tecidual amarela e outra com seleção de área tecidual vermelha, já convertida em preto e branco. 


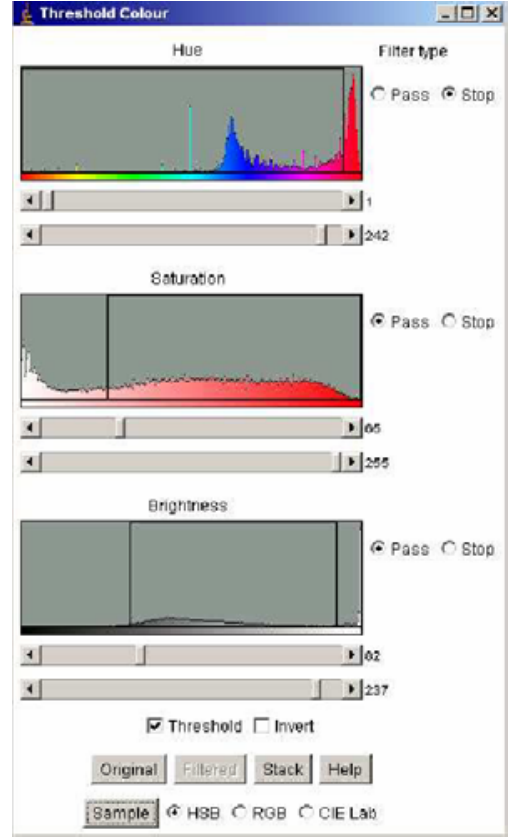

(a)

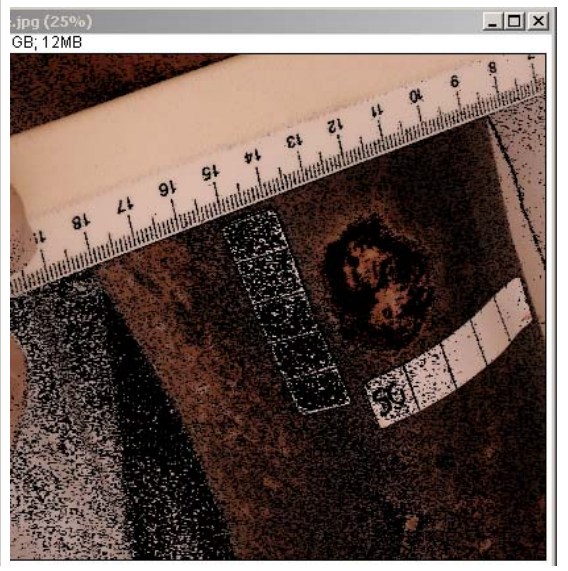

(b)

Figura 3.10 - (a) Plugin threshold_colour; (b) exemplo de uma imagem de úlcera com seleção de fibrina

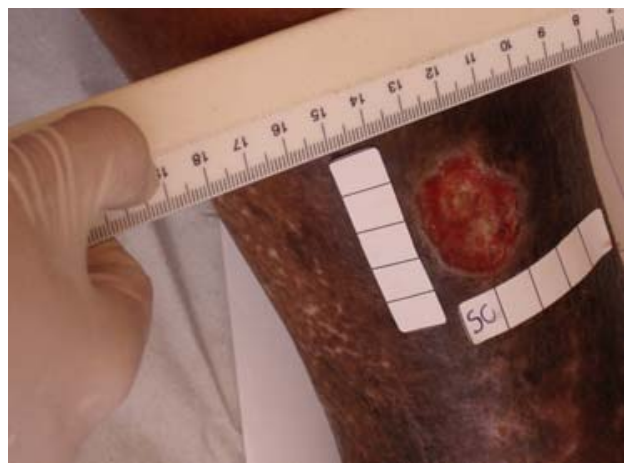

Figura 3.11 - Imagem real da ferida

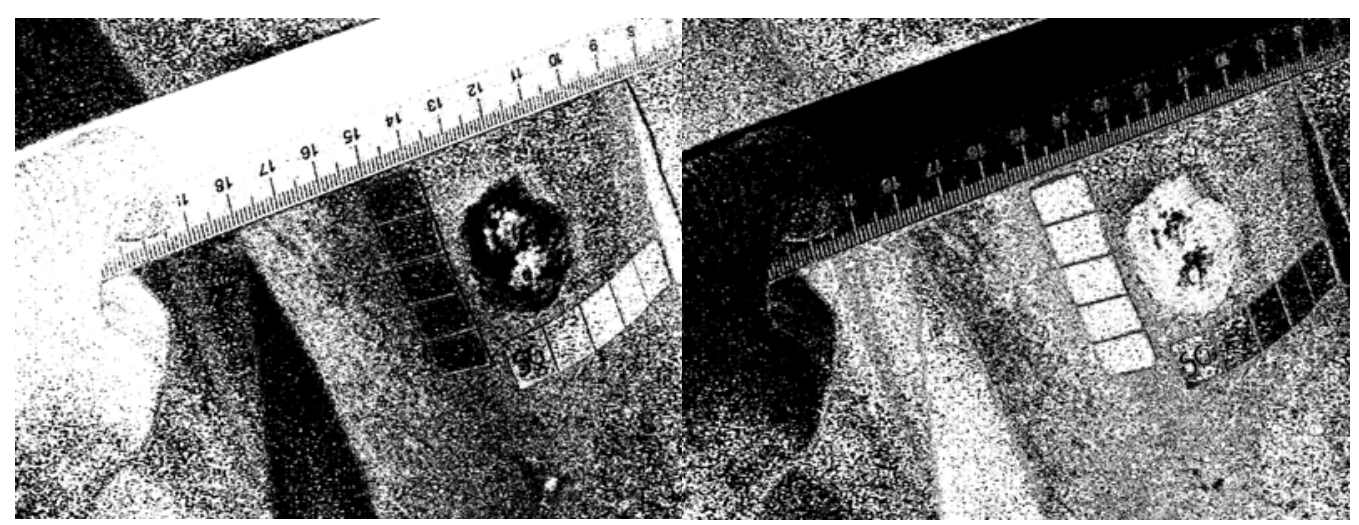

Figura 3.12 - Imagem com seleção de fibrina e imagem com seleção de granulação, respectivamente

Na análise imunohistoquímica, para a seleção da área de cor cobre, foi 
utilizado o $\mathrm{Gimp}^{\circledR}$, software empregado na formatação de imagens, semelhante ao Photoshop ${ }^{\circledR}$, porém disponível na Internet. Optou-se pelo Gimp ${ }^{\circledR}$ para a seleção da área de cor cobre por ser mais preciso que o Image $^{\circledR}$ quando as imagens mostram problemas de background, isto é, restos de enzimas ou fatores de crescimento espalhados sobre a amostra, decorrentes do processo de imunohistoquímica. Este background não faz parte da área de interesse. A imagem foi decomposta em RGB, que é a abreviatura do sistema de cores aditivas formado por vermelho (Red), verde (Green) e azul (Blue). A escala de RGB varia de 0 (mais escuro) a 255 (mais claro). O RGB converte a imagem em escalas de cinza, nos 3 sistemas de cores. Foi utilizada a imagem em escala de cinza na cor verde, já que esta representou melhor a cor cobre e violeta da amostra. A figura 3.13a ilustra a imagem real de uma amostra de imunohistoquímica, comparada à imagem convertida em escala de cinza na cor verde pelo Gimp ${ }^{\circledR}$ (figura 3.13b). Observa-se que a área de interesse, ou seja, células marcadas com cobre, está na cor preta de tonalidade mais forte; já o background está em tons de preto desbotado, cinza ou branco.

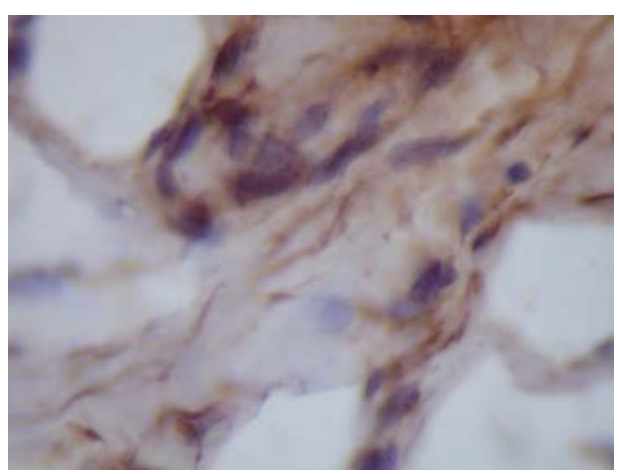

3.13a - Imagem real da imunohistoquímica

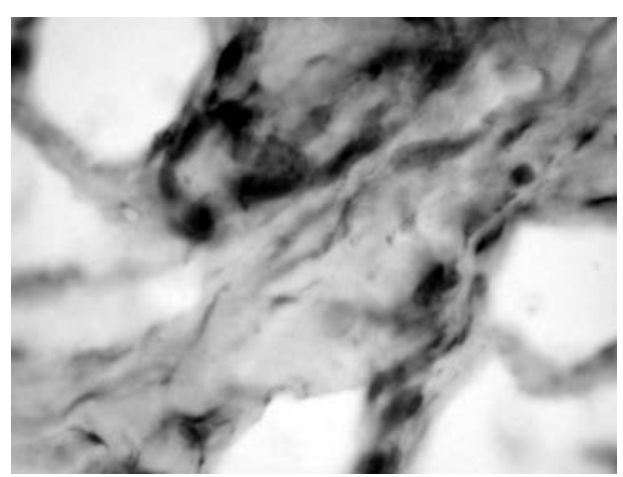

3.13b - Imagem da imunohistoquímica em escala de cinza na cor verde

Em seguida, a imagem em escala de cinza na cor verde foi analisada no Image $^{\circledR}$, através do plugin threshold (figura 3.14). O software torna, por exemplo, vermelha a área de interesse. A figura 3.15 mostra a imagem com seleção da cor cobre, já convertida em vermelha. 


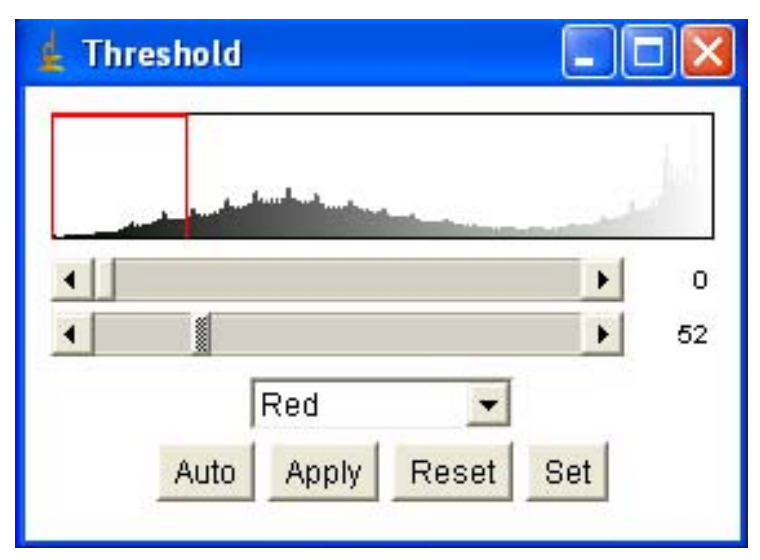

Figura 3.14 - Plugin threshold

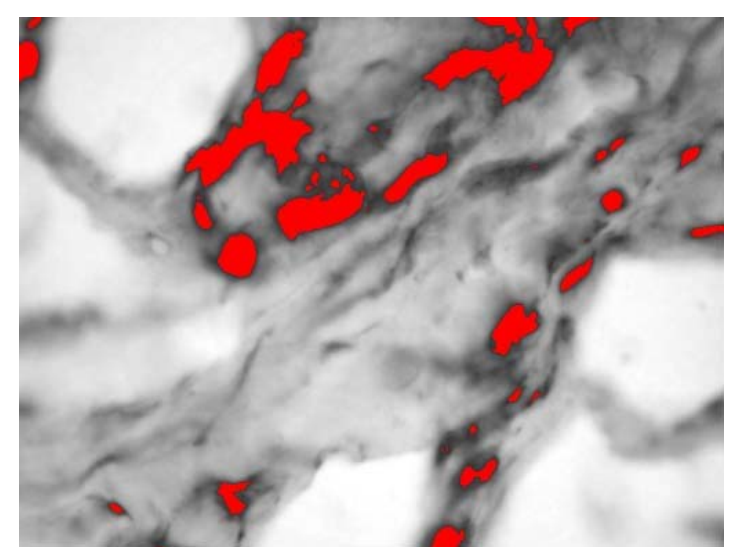

Figura 3.15 - Imagem com seleção da cor cobre

Etapa 5: Após ter sido definida a área de interesse, isto é, branco na análise da área da úlcera, e vermelho na análise histoquímica (figura 3.16 e 3.17), ela é quantificada pelo software Image $\mathrm{J}^{\circledR}$. No caso da imunohistoquimica, a área avaliada foi todo o campo fotografado e o cálculo da área de interesse é também realizado pelo comando $<$ Ctrl $M>$, após ajuste apropriado da escala. As escalas das imagens foram calibradas utilizando as etiquetas auto-colantes. A escala da imunohistoquímica foi calibrada utilizando uma régua micrométrica fotografada nos mesmos padrões das amostras.

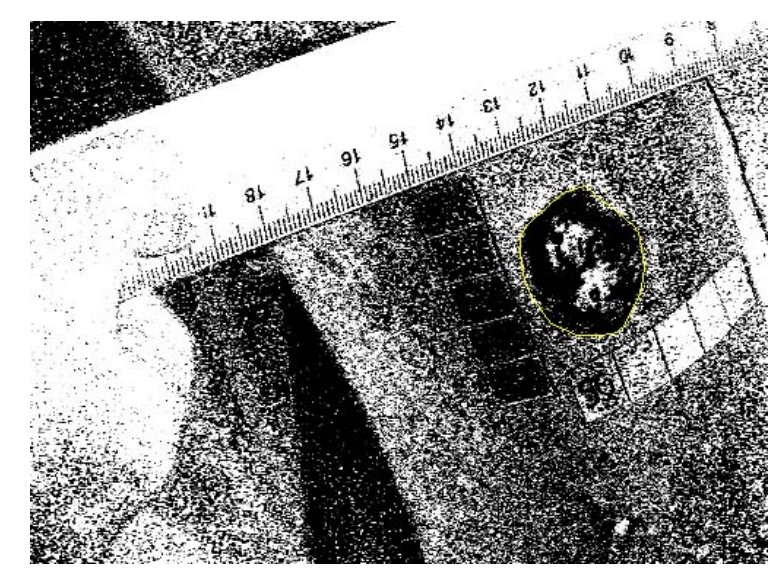




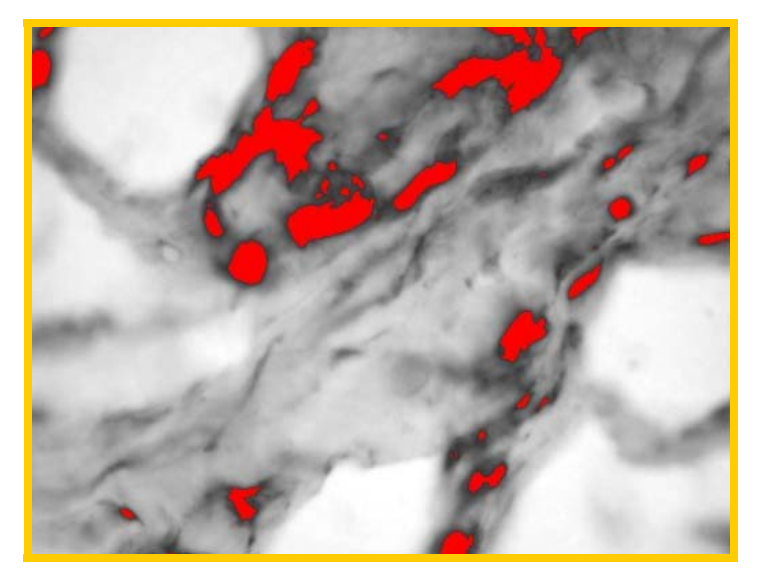

Figura 3.16 - Seleção de área de fibrina

Figura 3.17 - Seleção de área da cor cobre

\subsection{Estudo Imunohistoquímico}

Para o estudo imunohistoquímico foram obtidas biópsias das úlceras realizadas no início do tratamento (pré-tratamento) e após 45 dias para a verificação das modificações teciduais (pós-tratamento) produzidas pelo tratamento convencional e por ultra-som.

Foi realizada anestesia local e incisão com punch de $4 \mathrm{~mm}$ na borda da úlcera com a intenção de se retirar o mínimo de fragmento necessário sem causar dano significativo ao paciente, sob responsabilidade do $\operatorname{Prof}^{\circ}$. $\mathrm{Dr}^{\circ}$. Marco Andrey Cipriani Frade.

As peças biopsiadas foram colocadas em soro fisiológico $(0,9 \%$ de $\mathrm{NaCl})$, em seguida acondicionadas em "Tissue $T_{e}{ }^{\circledR ”}$ e congeladas à temperatura de $70^{\circ} \mathrm{C}$.

Os exames imunohistoquímicos foram realizados no Laboratório de Inflamação e Dor do Departamento de Farmacologia da FMRP-USP.

OBS: As informações colhidas e observações clínicas constatadas pelo exame estão arquivadas. Esses dados serão utilizados exclusivamente para fins técnicocientificos. 
Alguns fragmentos foram submetidos ao estudo imunohistoquímico para quantificação de TGF- $\beta$, VEGF e iNOS, utilizando o Método HRP-Streptavidina (Santa Cruz Biotechnology) (ANEXO C). A quantificação dos fatores de crescimento e da enzima foi realizada através do software Image $^{\circledR}$.

O Método HRP-Streptavidina marca as células que contém TGF- $\beta$, VEGF e iNOS com a cor cobre e as demais com a cor violeta.

\subsection{Parâmetros Quantificados}

Foram quantificados os seguintes parâmetros

a) área das úlceras e dos tecidos de granulação e fibrina.

b) razão $\left(r_{1}\right)$ entre a área inicial da úlcera menos a área no dia da avaliação dividido pela área inicial com a seguinte interpretação: área fechada se $r_{1}=1$, área inalterada se $r_{1}=0$, diminuição da área se $r_{1}>1$ e aumento da área se $r_{1}<1$.

c) razão $\left(r_{2}\right)$ entre a área do tecido de granulação e a área da úlcera no mesmo dia da avaliação.

d) razão $\left(r_{3}\right)$ entre a área do tecido de fibrina e a área superficial da úlcera no mesmo dia da avaliação.

e) área das células marcadas pela presença da enzima iNOS e pelos fatores de crescimento TGF $\beta$ e VEGF com aumento de 400X. A medida foi realizada em 5 campos de um mesmo corte histológico para obtenção de uma média.

\subsection{Testes de Validação do Image ${ }^{\circledR}$}


Cinco estudos foram realizados no "Ambulatório de Úlceras" do "Centro de Saúde Escola" da FMRP-USP com os seguintes objetivos:

Estudo 1: validação da medida da área das úlceras através do software Image $J^{\circledR}$ :

Estudo 2: comparação de análises de imagem realizadas pelo software Image $J^{\circledR}$ captadas com câmara digital e com o uso de folha plástica.

Estudo 3: comparação entre técnica convencional de análise de imagem e a realizada pelo Image $\mathrm{J}^{\circledR}$.

Estudo 4: influência da captura de imagem através de método não padronizado e padronizado na análise de imagem.

Estudo 5: influência da segmentação manual da borda da úlcera do tecido de granulação e fibrina realizada através de mouse na análise de imagem.

\section{Estudo 1}

\section{Procedimento:}

a) corte de um papel milimetrado para se obter uma área S com formato regular ou irregular.

b) medida da massa média do mesmo papel em amostras com área de $1 \mathrm{~cm}^{2}$ (área padrão).

c) medida da massa do papel contendo a área $\mathrm{S}$ em uma balança de precisão.

d) cálculo da área $S$ através da razão entre a medida da massa do papel com área regular e irregular e a medida da média da massa do papel com a área padrão.

e) fotografia da área regular ou irregular para medida da área através de análise de imagem pelo software Image $\mathrm{J}^{\circledR}$. 
Foram utilizadas 4 áreas regulares (quadrados com lado de 2, 3, 4 e $5 \mathrm{~cm}$ ) e 5 áreas irregulares e calculado o erro entre o valor da área medida pelo software e a área medida através do peso.

\section{Estudo 2}

Procedimento: Um total de 25 úlceras foram fotografadas com câmera digital e desenhadas em dupla folha plástica transparente colocadas simultaneamente sobre a úlcera (método manual). A folha em contato com a úlcera foi descartada. Para os desenhos foram usados pincéis marcadores de cor vermelha para o delineamento da área ulcerada e pintura de toda área de tecido de granulação e de cor azul para fibrina. Os desenhos de cada úlcera foram também fotografados para análise pelo Image $^{\circledR}$.

\section{Estudo 3}

Procedimento: As áreas das úlceras fotografadas e analisadas pelo Image $^{\circledR}$ no estudo 2 foram comparadas com as úlceras desenhadas no estudo 2 e analisadas com os seguintes métodos tradicionais de análise de imagem:

- $\quad$ aproximação da área da úlcera por um retângulo com lados iguais aos diâmetros maiores no sentido longitudinal e transversal.

- $\quad$ aproximação da área da úlcera por uma elipse com área $S=\pi a b$, sendo a 0 eixo maior e b o eixo menor.

medida da área com o uso de papel centimetrado.

\section{Estudo 4}


Procedimento: Um total de 30 úlceras foram utilizadas para medida da área e dos tecidos de granulação e de fibrina utilizando uma captura de imagem padronizada (ver 3.4.1) e não padronizada (iluminação ambiente e sem o dispositivo fotográfico).

\section{Estudo 5}

Procedimento: Um total de 15 úlceras foram utilizadas para determinação da área da úlcera e dos tecidos de granulação e fibrina utilizando-se o software Image $J^{\circledR}$. As medidas, segundo o procedimento do item 3.5 , foram realizadas por dois pesquisadores diferentes para se avaliar a influência humana nos resultados da análise de imagem.

\subsection{Análise Estatística}

As análises estatísticas dessa investigação foi realizada com o teste não paramétrico de Mann-Whitney, com nível de significância de 5\%. 
4. Resultados 


\subsection{Efeito da Camada de Látex na Transmissão do Ultra-som}

A influência da película foi quantificada através da medida da energia transmitida, com e sem a presença da mesma. A atenuação média causada pela película foi de $11 \%$, conforme descrito na Tabela 4.1 .

Tabela 4.1 - Influência da Película de Látex

\begin{tabular}{|c|c|c|c|}
\hline Medida & $\begin{array}{c}\text { Potência (mW) } \\
\text { (sem a película) }\end{array}$ & $\begin{array}{c}\text { Potência (mW) } \\
\text { (com a película) }\end{array}$ & $\begin{array}{c}\text { Diferença } \\
(\mathbf{m W})\end{array}$ \\
\hline 1 & 0,192 & 0,166 & $-0,026$ \\
\hline 2 & 0,19 & 0,16 & $-0,03$ \\
\hline 3 & 0,172 & 0,162 & $-0,01$ \\
\hline 4 & 0,182 & 0,16 & $-0,022$ \\
\hline 5 & 0,176 & 0,158 & $-0,018$ \\
\hline 6 & 0,18 & 0,16 & $-0,02$ \\
\hline 7 & 0,178 & 0,162 & $-0,016$ \\
\hline 8 & 0,18 & 0,162 & $-0,018$ \\
\hline Média & $\mathbf{0 , 1 8 1}$ & $\mathbf{0 , 1 6 1}$ & $-0,020$ \\
\hline
\end{tabular}

Obs: Atenuação média $=0,020 / 0,181=0,11=11 \%$

Considerando-se uma atenuação média de $11 \%$ produzida pela película de látex, a energia transmitida pelo transdutor foi regulada para transmitir uma intensidade de $30 \mathrm{~mW} / \mathrm{cm} 2$ com a presença da película.

\subsection{Dados Populacionais}

Os dados populacionais como idade, sexo, cor, profissão, doenças associadas e recorrências, relativos às duas amostras que constituíram os grupos 1 e 2, respectivamente, estão apresentados na tabela 4.2 
Tabela 4.2 - Dados populacionais do grupo 1 (SDZ) e do grupo 2 (US)

\begin{tabular}{|c|c|c|c|}
\hline \multicolumn{2}{|c|}{ Características Clínicas } & Grupo 1(n=7) & Grupo $2(n=9)$ \\
\hline \multirow{3}{*}{ Idade } & Média & 75,7 & 62,9 \\
\hline & Mínima & 59 & 36 \\
\hline & Máxima & 81 & 78 \\
\hline \multirow{2}{*}{ Sexo } & Masculino & $85,7 \%$ & $66,7 \%$ \\
\hline & Feminino & $14,3 \%$ & $33,3 \%$ \\
\hline \multirow{2}{*}{ Cor } & Branca & $28,6 \%$ & $66,7 \%$ \\
\hline & Não Branca & $71,4 \%$ & $33,3 \%$ \\
\hline \multirow{2}{*}{ Profissão } & Inativa & $85,8 \%$ & $66,7 \%$ \\
\hline & Ativa & $14,2 \%$ & $33,3 \%$ \\
\hline \multirow{4}{*}{$\begin{array}{c}\text { Doenças } \\
\text { Associadas }\end{array}$} & IVC & $\mathrm{X}$ & $22,2 \%$ \\
\hline & IVC+Artrite & $x$ & $11,1 \%$ \\
\hline & IVC+Diabetes & $x$ & $11,1 \%$ \\
\hline & IVC+HAS & $100 \%$ & $55,6 \%$ \\
\hline \multirow{2}{*}{ Recorrência } & Sim & $85,7 \%$ & $66,7 \%$ \\
\hline & Não & $14,3 \%$ & $33,3 \%$ \\
\hline
\end{tabular}

\subsection{Quantificação das Áreas das Úlceras e das Razões $r_{1}, r_{2}$ e $r_{3}$}

O seguimento clínico dos pacientes conforme protocolo de 90 dias foi realizado através de fotografias padronizadas a cada 15 dias, conforme as figuras 4.1a, 4.1b, 4.2a e 4.2b. No grupo 1 não houve desistência de nenhum paciente sendo que 7 pacientes completaram o protocolo. No grupo 2 houve duas desistências e 9 pacientes completaram o protocolo. 


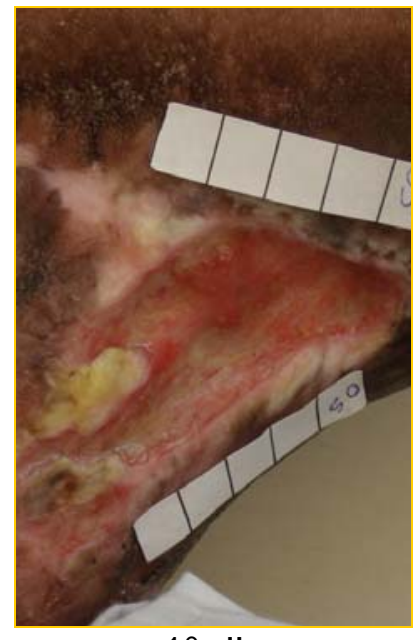

$1^{\circ} \mathrm{dia}$

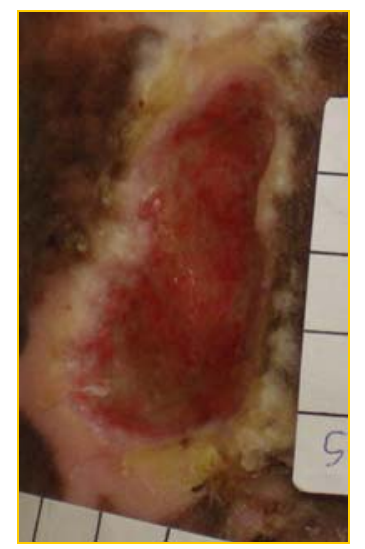

$1^{\circ}$ dia

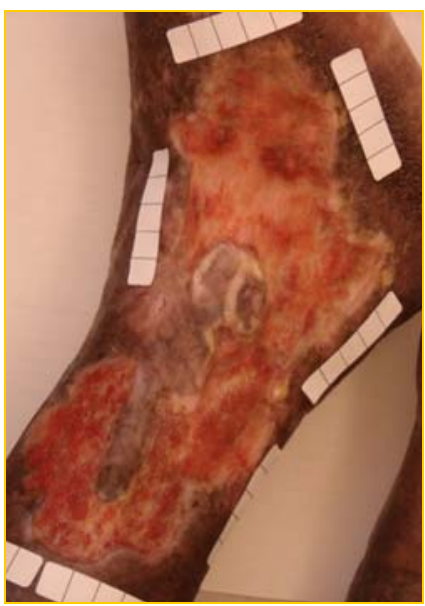

$1^{\circ}$ dia
Caso 1

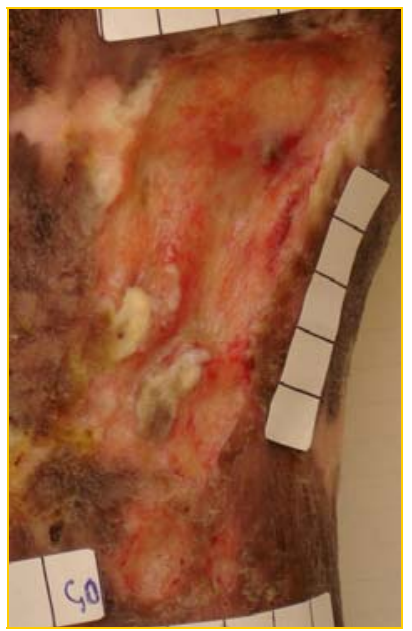

$45^{\circ}$ dia

Caso 2

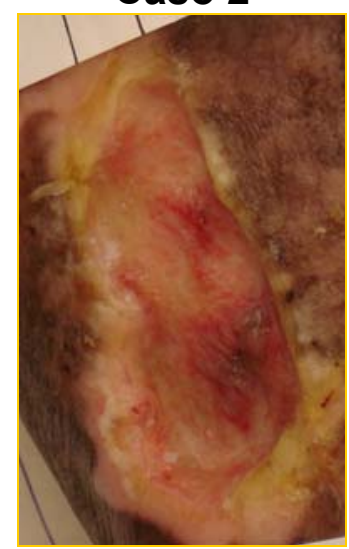

$45^{\circ}$ dia

Caso 3

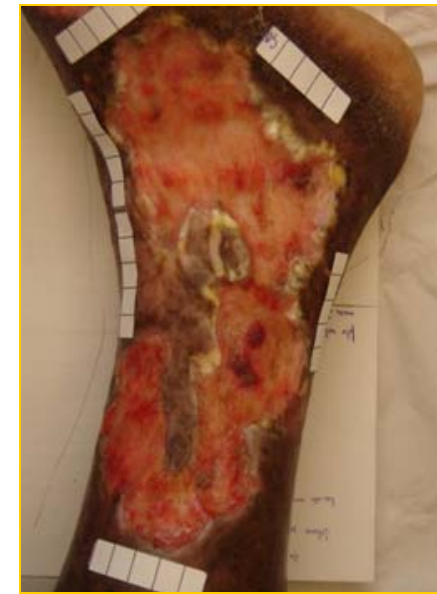

$45^{\circ}$ dia

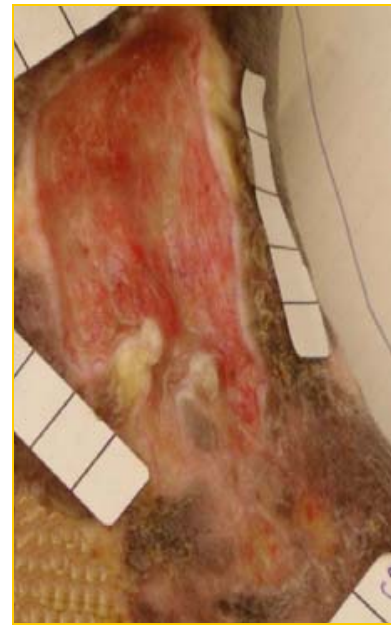

$90^{\circ} \mathrm{dia}$

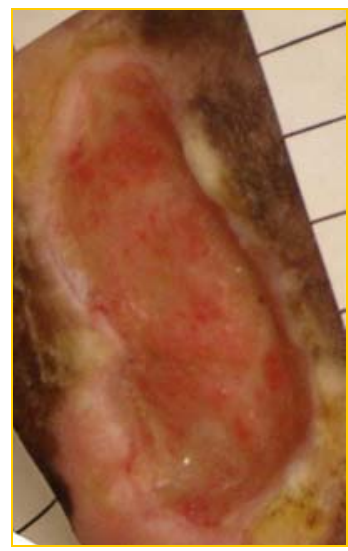

$90^{\circ} \mathrm{dia}$

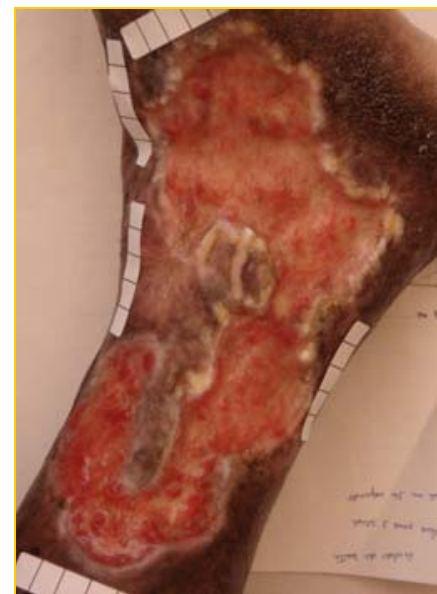

$90^{\circ}$ dia

Figura 4.1a - Seguimento clínico fotográfico dos pacientes do Grupo 1 


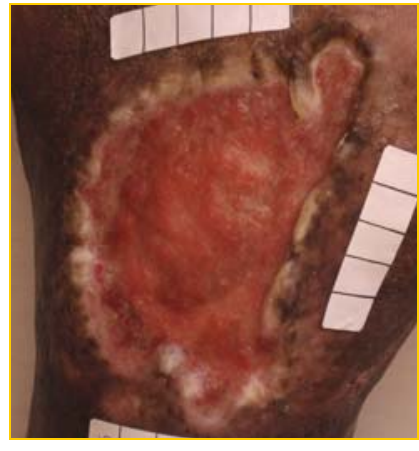

$1^{\circ} \mathrm{dia}$

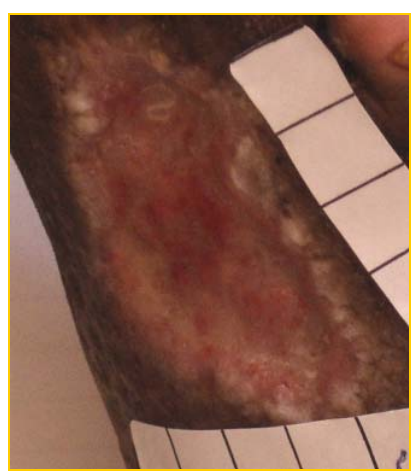

$1^{\circ} \mathrm{dia}$

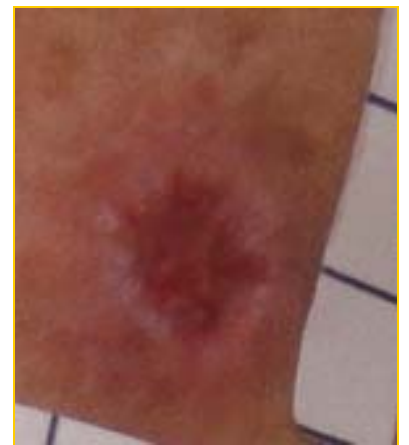

$1^{\circ}$ dia

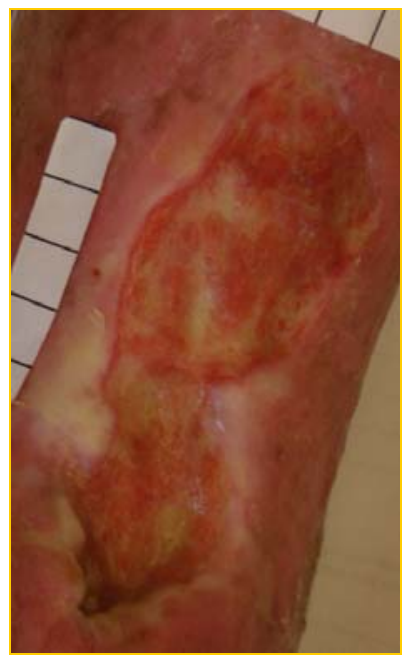

$1^{\circ}$ dia
Caso 4

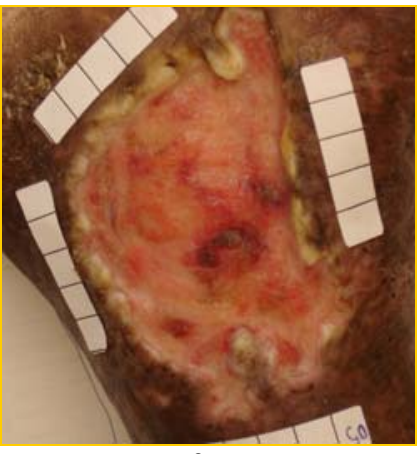

$45^{\circ}$ dia

Caso 5

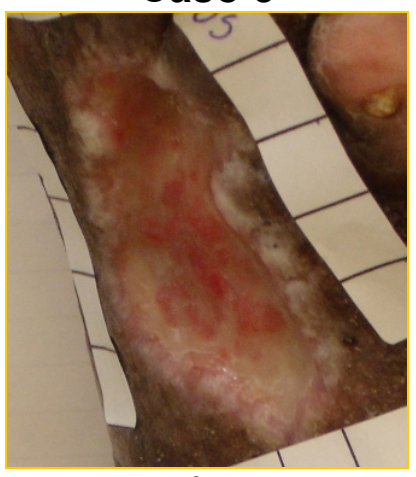

$45^{\circ}$ dia

Caso 6

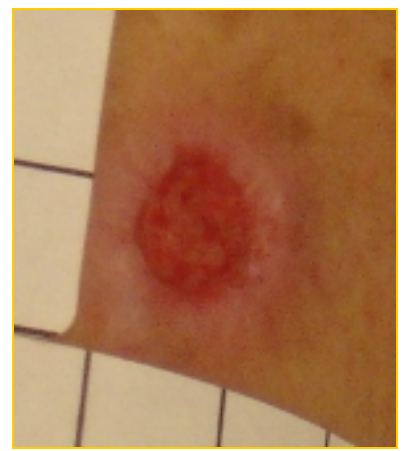

$45^{\circ}$ dia

Caso 7

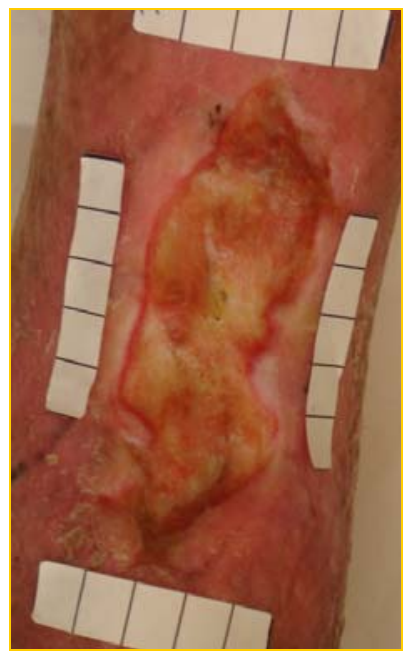

$45^{\circ}$ dia

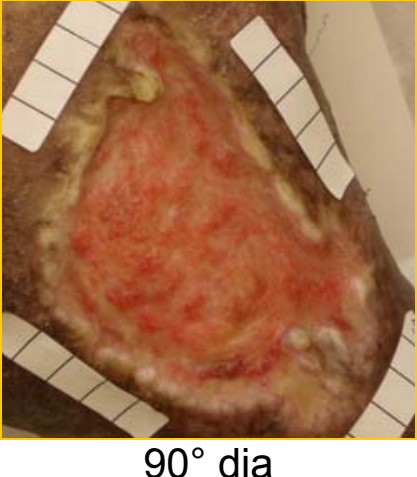

$90^{\circ}$ dia

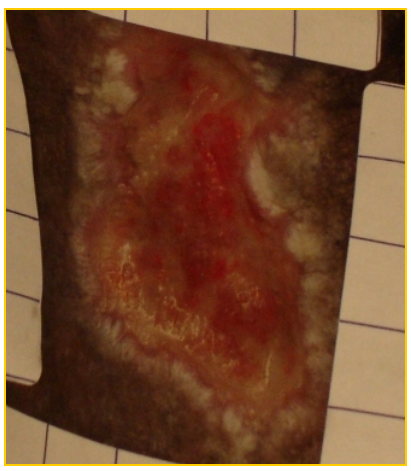

$90^{\circ}$ dia

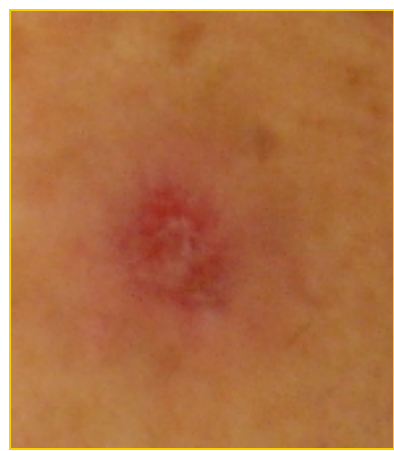

$90^{\circ}$ dia

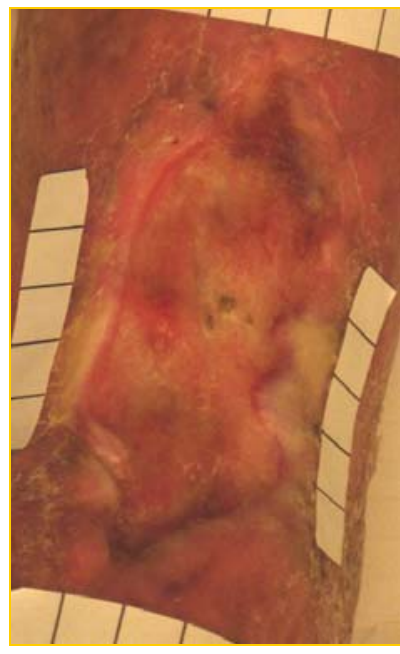

$90^{\circ}$ dia

Figura 4.1b - Seguimento clínico fotográfico dos pacientes do Grupo 1 


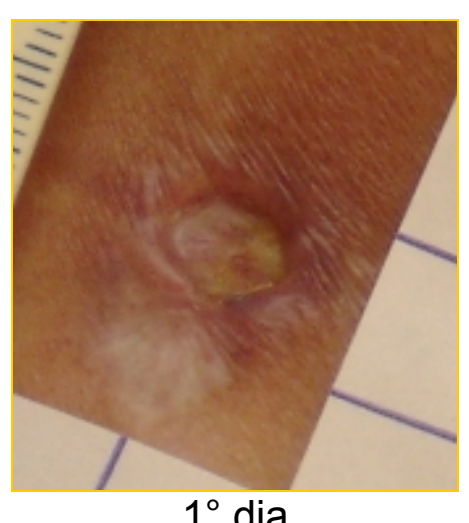

$1^{\circ}$ dia

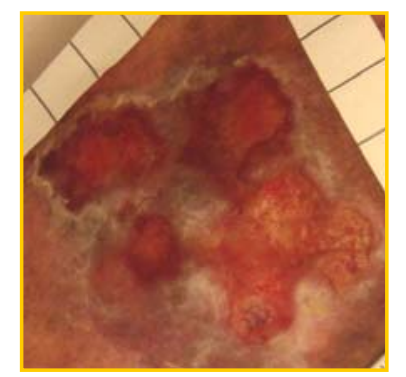

$1^{\circ}$ dia

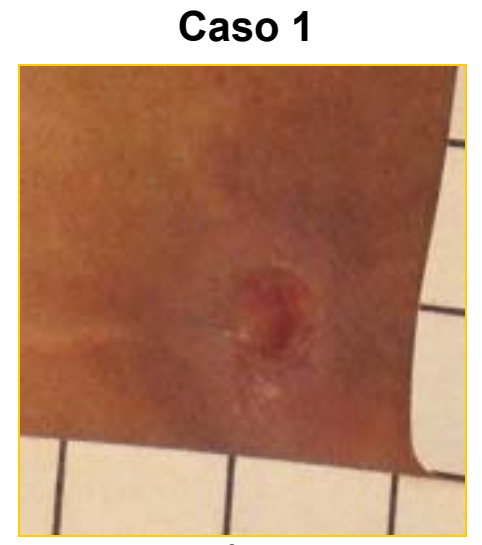

$45^{\circ}$ dia

Caso 2

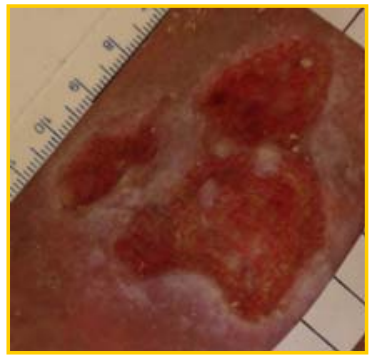

$45^{\circ}$ dia

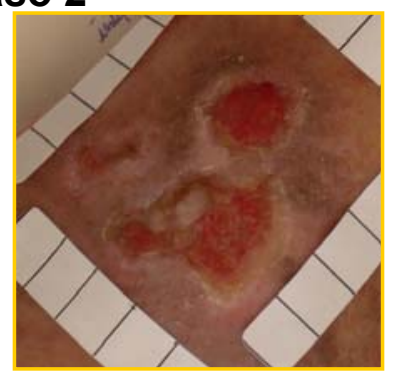

$90^{\circ}$ dia

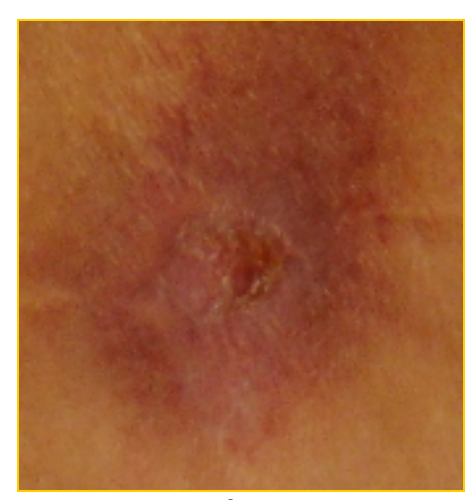

$90^{\circ}$ dia

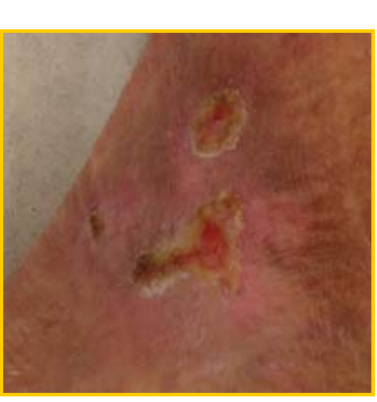

$105^{\circ} \mathrm{dia}$

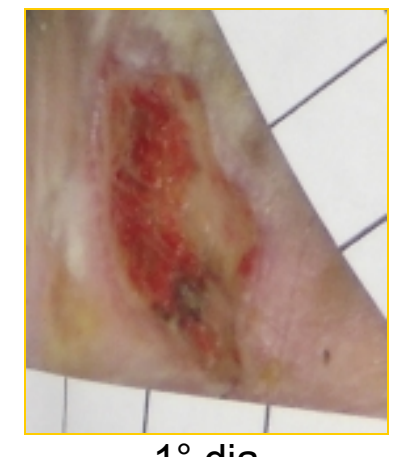

$1^{\circ}$ dia

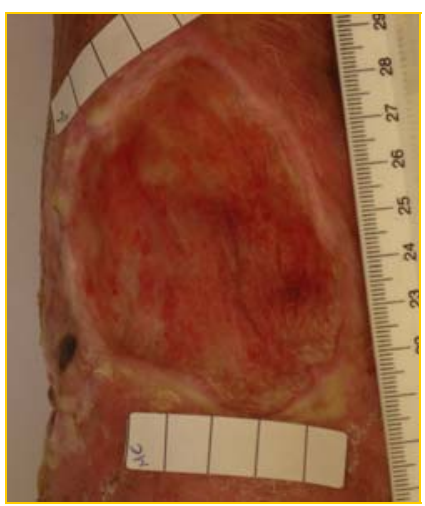

$1^{\circ}$ dia

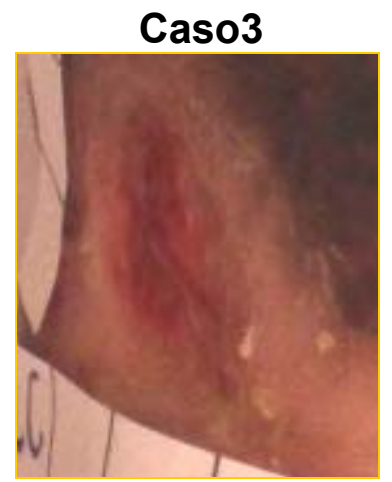

$45^{\circ}$ dia

Caso 4

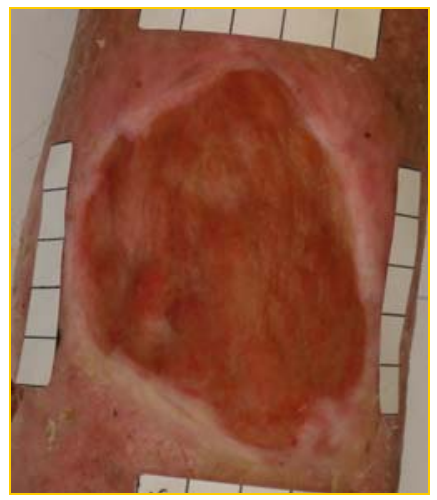

$45^{\circ}$ dia

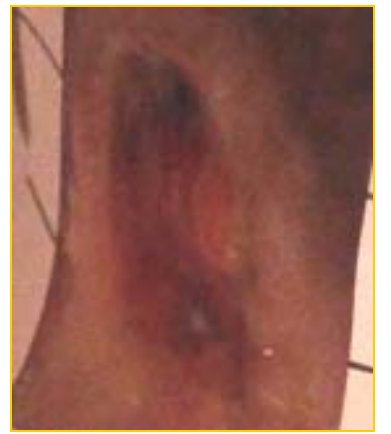

$90^{\circ}$ dia

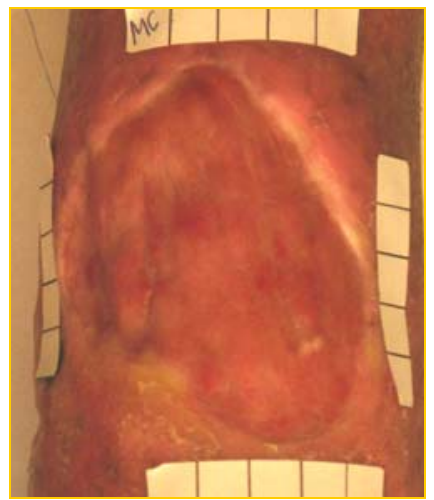

$90^{\circ}$ dia

Figura 4.2a - Seguimento clínico fotográfico dos pacientes do Grupo 2 


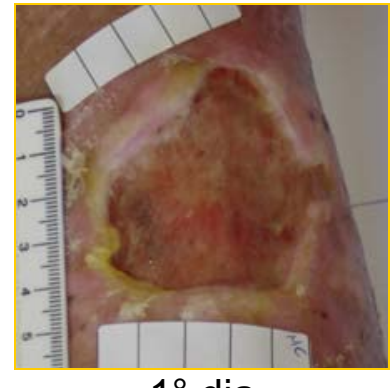

$1^{\circ}$ dia

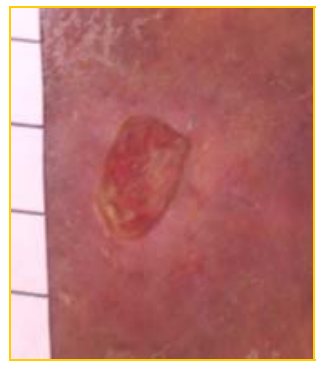

$1^{\circ}$ dia

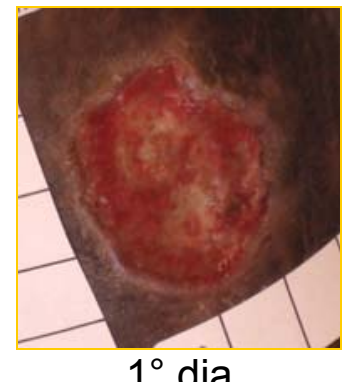

$1^{\circ}$ dia

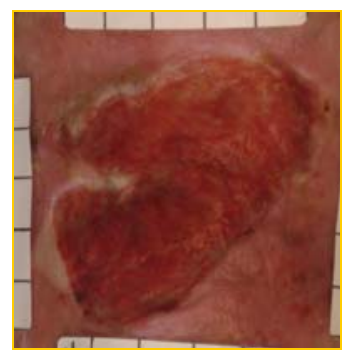

$1^{\circ}$ dia

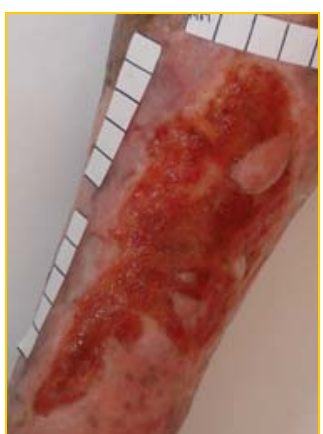

$1^{\circ} \mathrm{dia}$

\section{Caso 5}

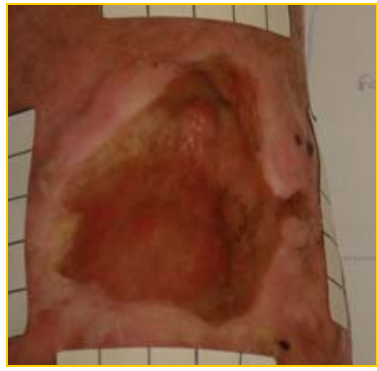

$45^{\circ}$ dia

Caso 6

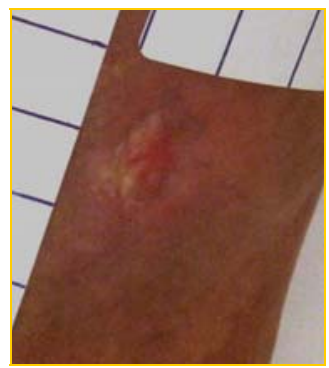

$45^{\circ}$ dia

Caso 7

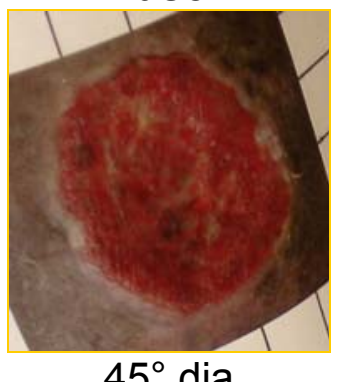

\section{Caso 8}

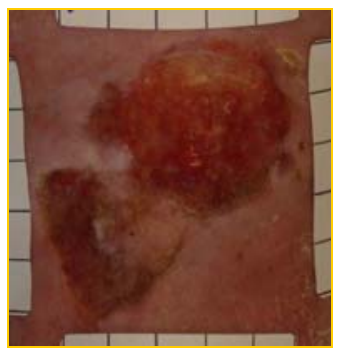

$45^{\circ}$ dia

Caso 9

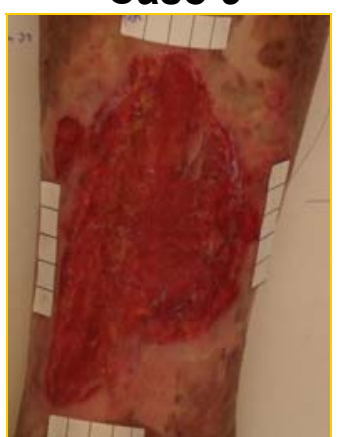

$45^{\circ}$ dia

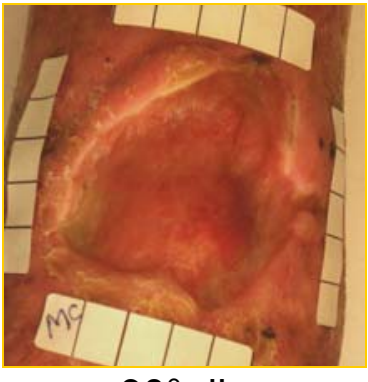

$90^{\circ}$ dia

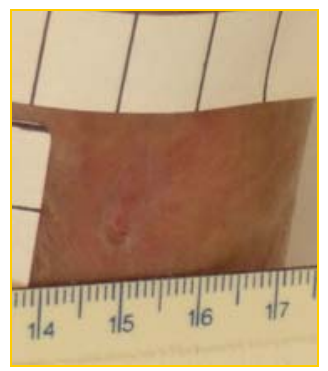

$90^{\circ}$ dia
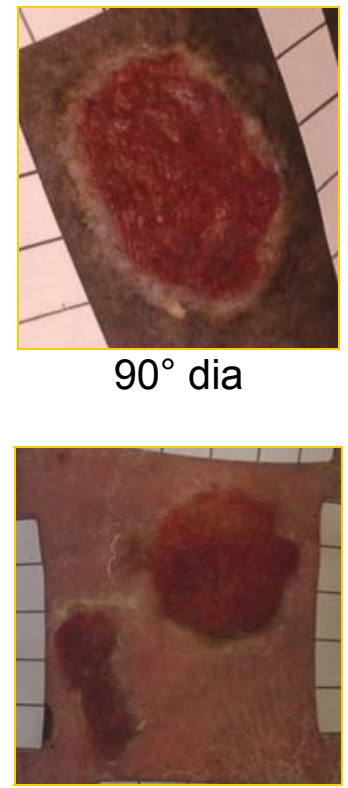

$90^{\circ}$ dia

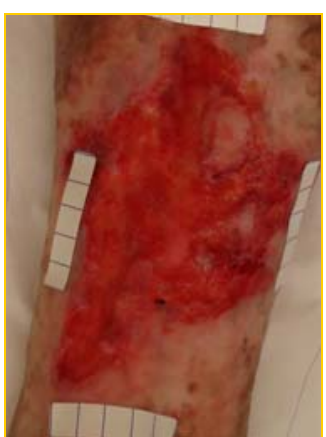

$90^{\circ}$ dia

Figura 4.2b - Seguimento clínico fotográfico dos pacientes do Grupo 2 
A evolução das áreas das úlceras de perna do grupo 1 (SDZ) e do grupo 2 (US) e dos respectivos tecidos de granulação e fibrina estão descritas no Anexo D.

A razão $r_{1}$ está descrita nas tabelas $4.3 a$ e $4.3 b$ e nos gráficos 4.1 a e $4.1 b . A$ evolução de $r_{1}$ com o tempo é descrita na tabela 4.4 .

Tabela 4.3a - Razão $r_{1}$ das úlceras de perna do grupo 1 (SDZ)

\begin{tabular}{|c|c|c|c|c|c|c|c|}
\hline Dia & $1^{\circ}$ & $15^{\circ}$ & $30^{\circ}$ & $45^{\circ}$ & $60^{\circ}$ & $75^{\circ}$ & $90^{\circ}$ \\
\hline 1 & 0,00 & 0,00 & $-0,88$ & $-0,98$ & $-0,44$ & $-0,50$ & $-0,54$ \\
\hline 2 & 0,00 & 0,05 & $-0,51$ & $-0,16$ & $-0,04$ & $-0,22$ & $-0,15$ \\
\hline 3 & 0,00 & $-0,02$ & $-0,19$ & $-0,33$ & $-0,04$ & 0,02 & $-0,22$ \\
\hline 4 & 0,00 & $-0,01$ & 0,02 & 0,02 & 0,23 & 0,17 & $-0,12$ \\
\hline 5 & 0,00 & 0,02 & 0,04 & 0,17 & $-0,24$ & $-0,22$ & $-0,15$ \\
\hline 6 & 0,00 & 0,10 & 1,00 & 1,00 & 1,00 & 1,00 & 1,00 \\
\hline 7 & 0,00 & 0,07 & $-0,03$ & 0,00 & $-0,01$ & $-0,02$ & $-0,02$ \\
\hline $\begin{array}{c}\text { Média } \\
\text { Desvio Padrão }\end{array}$ & - & $\begin{array}{l}0,03 \\
0,04\end{array}$ & $\begin{array}{c}-0,08 \\
0,58\end{array}$ & $\begin{array}{c}-0,04 \\
0,59\end{array}$ & $\begin{array}{l}0,07 \\
0,46\end{array}$ & $\begin{array}{l}0,03 \\
0,48\end{array}$ & $\begin{array}{l}0,00 \\
0,48\end{array}$ \\
\hline
\end{tabular}

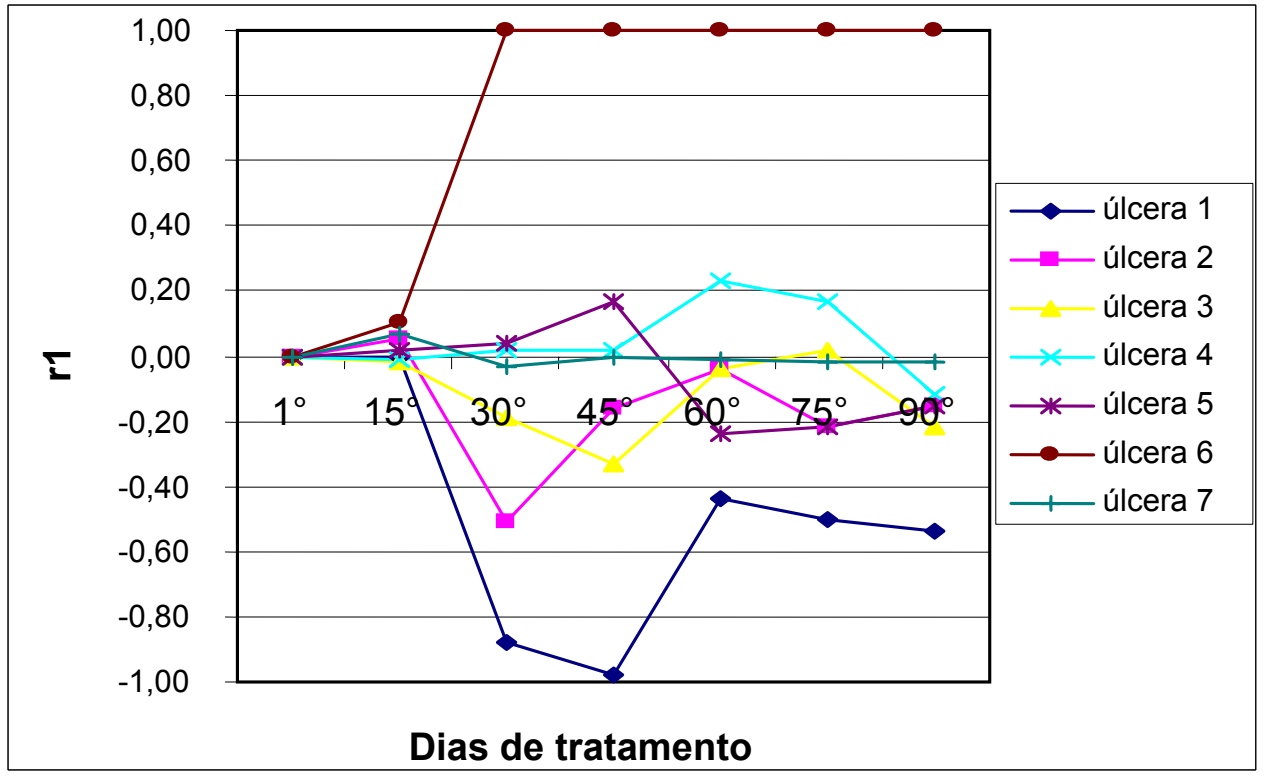

Gráfico 4.1a - Razão $r_{1}$ das úlceras de perna do grupo 1 (SDZ) 
Tabela 4.3b - Razão $r_{1}$ das úlceras de perna do grupo 2 (US)

\begin{tabular}{|c|c|c|c|c|c|c|c|c|}
\hline & $\mathbf{1}^{\circ}$ & $\mathbf{1 5}^{\circ}$ & $\mathbf{3 0}^{\circ}$ & $\mathbf{4 5}^{\circ}$ & $\mathbf{6 0}^{\circ}$ & $\mathbf{7 5}^{\circ}$ & $\mathbf{9 0}^{\circ}$ & $\mathbf{1 0 5}^{\circ}$ \\
\hline 1 & & & & & & & & \\
\hline 2 & 0,00 & $-0,41$ & 0,00 & 0,66 & 1,00 & 1,00 & 1,00 & - \\
\hline 3 & 0,00 & $-0,35$ & $-0,47$ & $-0,55$ & $-0,10$ & 0,25 & 0,67 & 1,00 \\
\hline 4 & 0,00 & $-0,19$ & $-0,08$ & 0,04 & 0,07 & 0,16 & 0,00 & - \\
\hline 5 & 0,00 & $-0,40$ & $-0,51$ & $-0,54$ & $-0,36$ & $-0,65$ & $-0,21$ & - \\
\hline 6 & 0,00 & $-0,06$ & 0,30 & 0,48 & 1,00 & 1,00 & 1,00 & - \\
\hline 7 & 0,00 & 0,19 & $-0,05$ & $-0,19$ & $-0,10$ & 0,00 & 0,13 & - \\
\hline 8 & 0,00 & 0,20 & 0,38 & 0,32 & 0,32 & 0,33 & 0,38 & - \\
\hline 9 & 0,00 & $-0,03$ & 0,00 & 0,27 & 0,07 & 0,39 & 0,43 & - \\
\hline \begin{tabular}{c} 
Média \\
\hline
\end{tabular} & - & $-\mathbf{0 , 1 0}$ & $\mathbf{- 0 , 0 6}$ & $\mathbf{0 , 0 6}$ & $\mathbf{0 , 2 4}$ & $\mathbf{0 , 3 1}$ & $\mathbf{0 , 4 1}$ & - \\
\hline
\end{tabular}

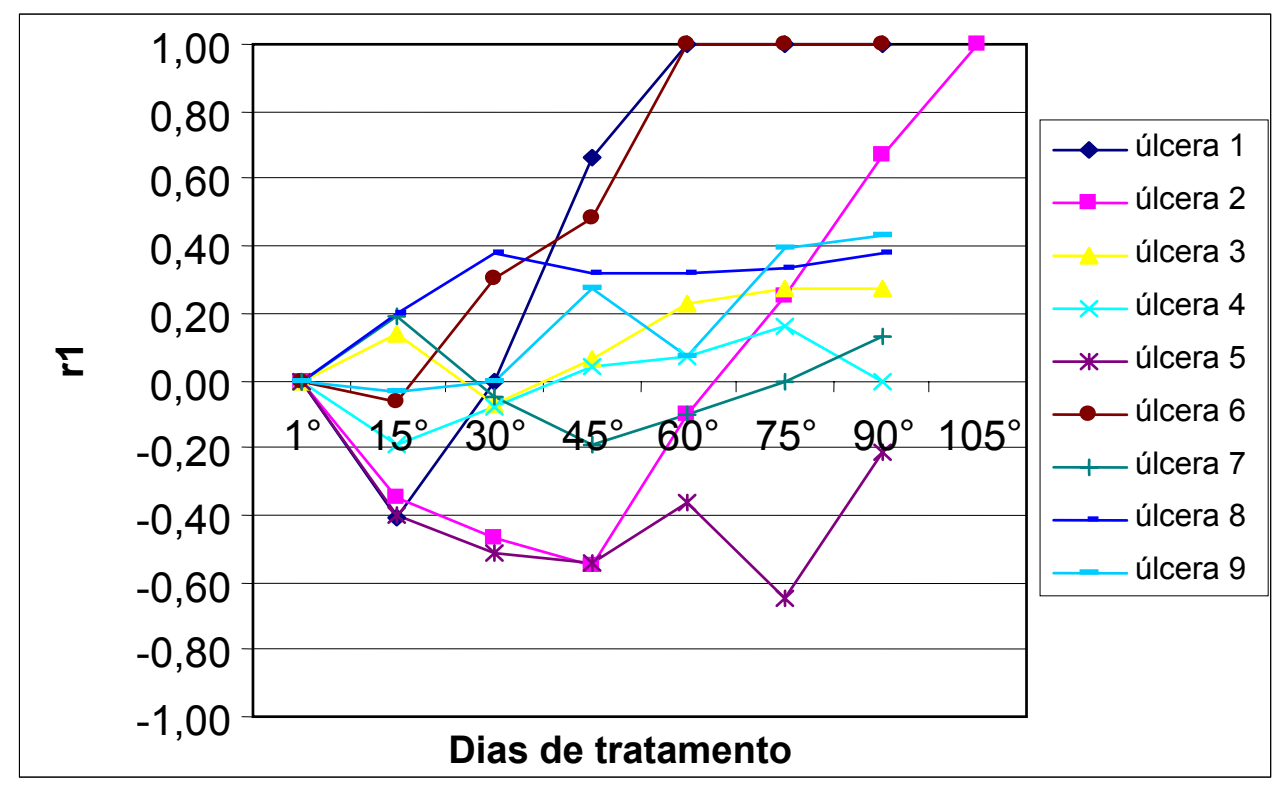

Gráfico 4.1b - Razão $r_{1}$ das úlceras de perna do grupo 2 (US) 
$\mathrm{Na}$ tabela 4.4 as úlceras foram distribuídas conforme a razão $r_{1}$ considerando-se evolução satisfatória se $r_{1}>0$, estável se $r_{1}=0$ e insatisfatória $r_{1}<0$.

Tabela 4.4 - Evolução de $r_{1}$ com o tempo

\begin{tabular}{|c|c|c|c|}
\hline Tempo & Classificação & $\begin{array}{c}\text { Número } \\
\text { de úlceras } \\
\text { Grupo1 }(n=7)\end{array}$ & $\begin{array}{c}\text { Número de } \\
\text { úlceras } \\
\text { Grupo2 }(n=9)\end{array}$ \\
\hline \multirow{3}{*}{$15^{\circ}$} & Satisfatória & 4 & 3 \\
\hline & Estável & 1 & 0 \\
\hline & Insatisfatória & 2 & 6 \\
\hline \multirow{3}{*}{$30^{\circ}$} & Satisfatória & 3 & 2 \\
\hline & Estável & 0 & 2 \\
\hline & Insatisfatória & 4 & 5 \\
\hline \multirow{3}{*}{$45^{\circ}$} & Satisfatória & 3 & 6 \\
\hline & Estável & 1 & 0 \\
\hline & Insatisfatória & 3 & 3 \\
\hline \multirow{3}{*}{$60^{\circ}$} & Satisfatória & 2 & 6 \\
\hline & Estável & 0 & 0 \\
\hline & Insatisfatória & 5 & 3 \\
\hline \multirow{3}{*}{$75^{\circ}$} & Satisfatória & 3 & 7 \\
\hline & Estável & 0 & 1 \\
\hline & Insatisfatória & 4 & 1 \\
\hline \multirow{3}{*}{$90^{\circ}$} & Satisfatória & 1 & 7 \\
\hline & Estável & 0 & 1 \\
\hline & Insatisfatória & 6 & 1 \\
\hline
\end{tabular}

As razões $r_{2}$ e $r_{3}$ estão descritas nas tabelas $4.5 a$ e $4.5 b$ e nos gráficos $4.2 a$ e $4.2 \mathrm{~b}$ e nas tabelas $4.6 \mathrm{a}$ e $4.6 \mathrm{~b}$ e gráficos $4.3 \mathrm{a}$ e $4.3 \mathrm{~b}$, respectivamente. 
Tabela 4.5a - Razão $r_{2}$ das úlceras de perna do grupo 1(SDZ)

\begin{tabular}{|c|c|c|c|c|c|c|c|}
\hline Dia & $1^{\circ}$ & $15^{\circ}$ & $30^{\circ}$ & $45^{\circ}$ & $60^{\circ}$ & $75^{\circ}$ & $90^{\circ}$ \\
\hline 1 & 0,3 & 0,51 & 0,26 & 0,54 & 0,53 & 0,71 & 0,57 \\
\hline 2 & 0,67 & 0,74 & 0,40 & 0,69 & 0,69 & 0,46 & 0,55 \\
\hline 3 & 0,55 & 0,48 & 0,53 & 0,50 & 0,56 & 0,59 & 0,67 \\
\hline 4 & 0,89 & 0,81 & 0,24 & 0,50 & 0,75 & 0,40 & 0,39 \\
\hline 5 & 0,75 & 0,32 & 0,42 & 0,54 & 0,54 & 0,66 & 0,72 \\
\hline 6 & 0,94 & 0,86 & 0,00 & - & - & - & - \\
\hline 7 & 0,67 & 0,79 & 0,71 & 0,58 & 0,73 & 0,72 & 0,80 \\
\hline $\begin{array}{c}\text { Média } \\
\text { Desvio Padrão }\end{array}$ & $\begin{array}{l}0,70 \\
0,18\end{array}$ & $\begin{array}{l}0,64 \\
0,21\end{array}$ & $\begin{array}{l}0,37 \\
0,23\end{array}$ & $\begin{array}{l}0,56 \\
0,07\end{array}$ & $\begin{array}{l}0,63 \\
0,10\end{array}$ & $\begin{array}{l}0,59 \\
0,13\end{array}$ & $\begin{array}{l}0,62 \\
0,15\end{array}$ \\
\hline
\end{tabular}

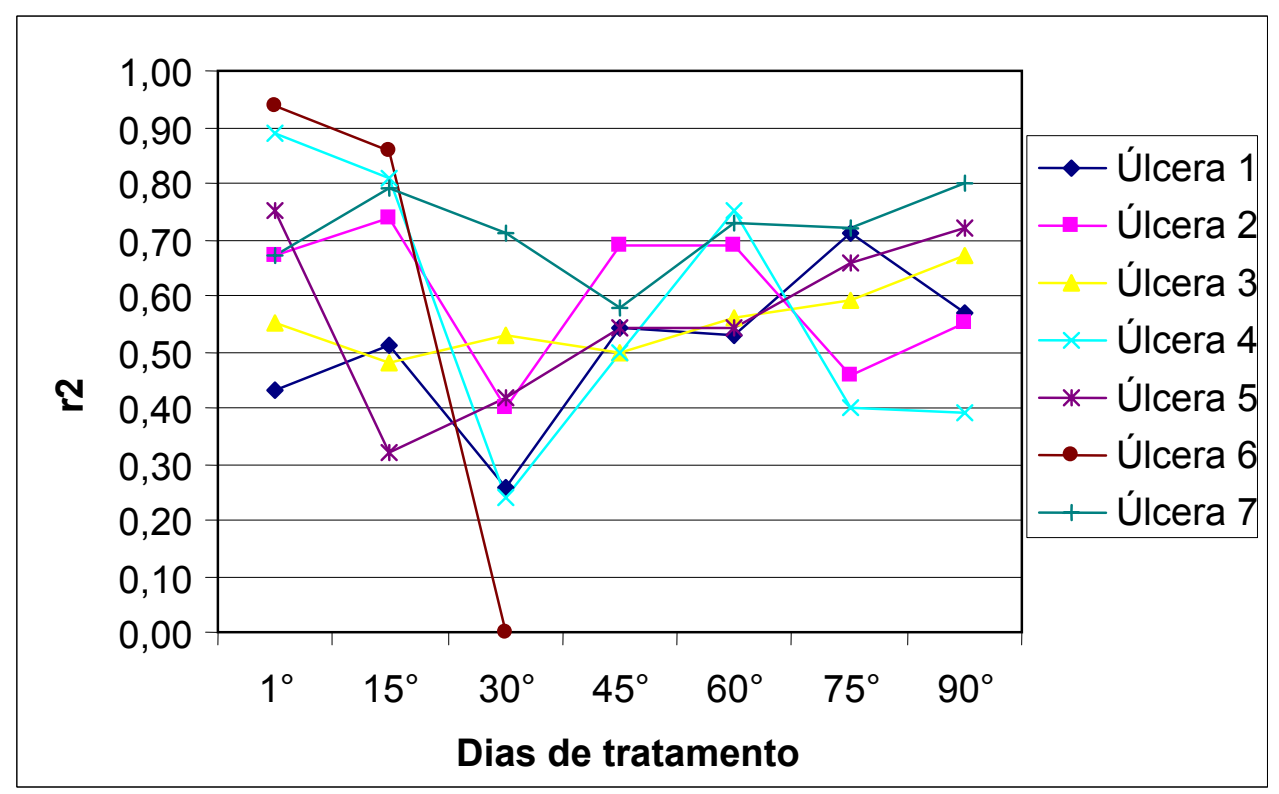

Gráfico 4.2a - Razão $r_{2}$ das úlceras de perna do grupo 1(SDZ) 
Tabela 4.5b - Razão $r_{2}$ das úlceras do grupo 2 (US)

\begin{tabular}{|c|c|c|c|c|c|c|c|c|}
\hline Dia & $1^{\circ}$ & $15^{\circ}$ & $30^{\circ}$ & $45^{\circ}$ & $60^{\circ}$ & $75^{\circ}$ & $90^{\circ}$ & $105^{\circ}$ \\
\hline 1 & 0,84 & 0,78 & 0,91 & 1,00 & 0,00 & - & - & - \\
\hline 2 & 0,80 & 0,80 & 0,81 & 0,81 & 0,94 & 0,84 & 0,87 & 0,00 \\
\hline 3 & 0,52 & 0,66 & 0,89 & 1,00 & 1,00 & 1,00 & 1,00 & - \\
\hline 4 & 0,59 & 0,62 & 0,74 & 0,71 & 0,68 & 0,77 & 0,73 & - \\
\hline 5 & 0,34 & 0,47 & 0,50 & 0,86 & 0,65 & 0,73 & 0,67 & - \\
\hline 6 & 0,84 & 0,53 & 0,65 & 0,70 & 0,00 & - & - & - \\
\hline 7 & 0,80 & 0,83 & 0,81 & 0,90 & 0,89 & 0,84 & 1,00 & - \\
\hline 8 & 0,83 & 0,59 & 0,69 & 0,67 & 0,61 & 0,78 & 0,88 & - \\
\hline 9 & 0,84 & 0,79 & 0,91 & 1,00 & 0,85 & 1,00 & 1,00 & - \\
\hline $\begin{array}{c}\text { Média } \\
\text { Desvio Padrão }\end{array}$ & $\begin{array}{l}0,71 \\
0,18\end{array}$ & $\begin{array}{l}0,67 \\
0,13\end{array}$ & $\begin{array}{l}0,77 \\
0,14\end{array}$ & $\begin{array}{l}0,85 \\
0,14\end{array}$ & $\begin{array}{l}0,62 \\
0,38\end{array}$ & $\begin{array}{l}0,85 \\
0,11\end{array}$ & $\begin{array}{l}0,88 \\
0,14\end{array}$ & - \\
\hline
\end{tabular}

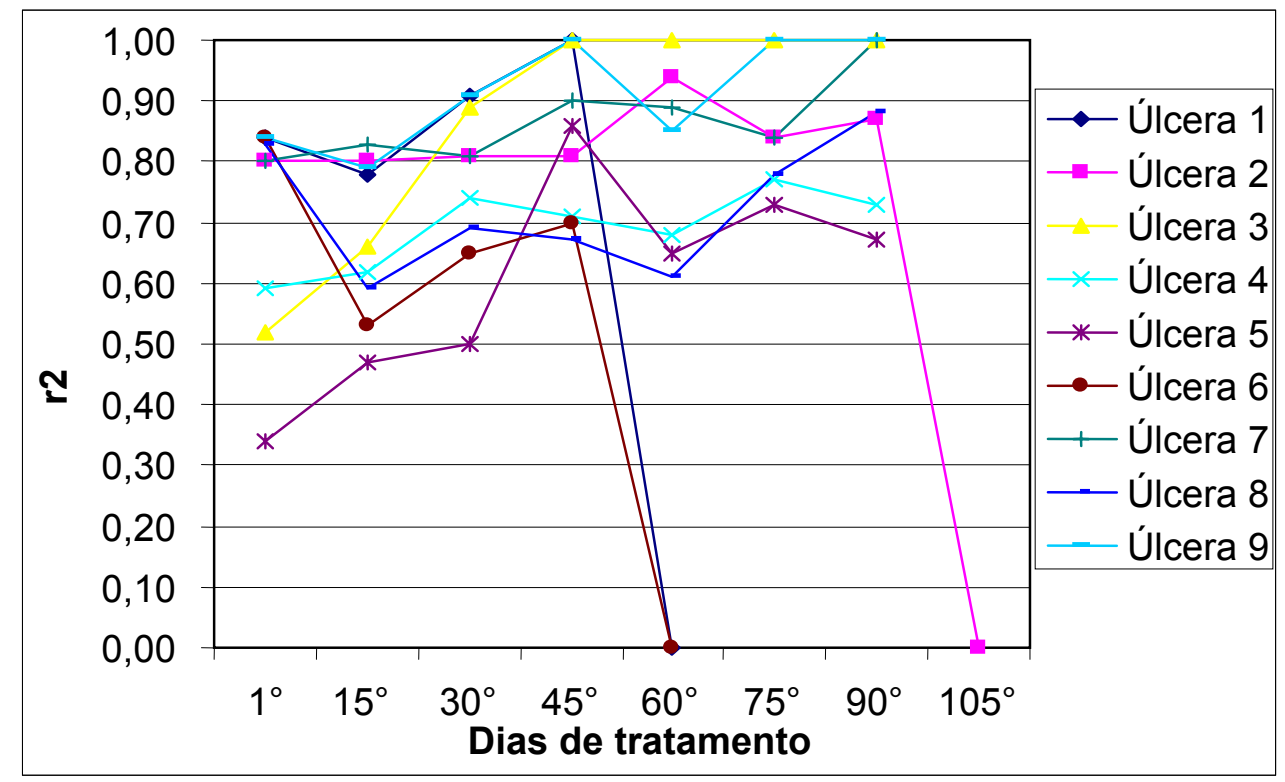

Gráfico 4.2b - Razão $r_{2}$ das úlceras do grupo 2 (US) 
Tabela 4.6a - Razão $r_{3}$ das úlceras do grupo 1(SDZ)

\begin{tabular}{|c|c|c|c|c|c|c|c|}
\hline Dia & $1^{\circ}$ & $15^{\circ}$ & $30^{\circ}$ & $45^{\circ}$ & $60^{\circ}$ & $75^{\circ}$ & $90^{\circ}$ \\
\hline 1 & 0,54 & 0,49 & 0,74 & 0,46 & 0,45 & 0,30 & 0,43 \\
\hline 2 & 0,31 & 0,26 & 0,59 & 0,31 & 0,32 & 0,54 & 0,45 \\
\hline 3 & 0,44 & 0,50 & 0,47 & 0,50 & 0,44 & 0,40 & 0,30 \\
\hline 4 & 0,11 & 0,12 & 0,76 & 0,51 & 0,25 & 0,59 & 0,62 \\
\hline 5 & 0,25 & 0,69 & 0,59 & 0,46 & 0,46 & 0,33 & 0,28 \\
\hline 6 & 0,00 & 0,14 & 0,00 & - & - & - & - \\
\hline 7 & 0,34 & 0,21 & 0,28 & 0,42 & 0,26 & 0,23 & 0,19 \\
\hline $\begin{array}{c}\text { Média士 } \\
\text { Desvio Padrão }\end{array}$ & $\begin{array}{l}0,28 \\
0,19\end{array}$ & $\begin{array}{l}0,34 \\
0,22\end{array}$ & $\begin{array}{l}0,49 \\
0,27\end{array}$ & $\begin{array}{l}0,44 \\
0,07 \\
\end{array}$ & $\begin{array}{l}0,36 \\
0,10 \\
\end{array}$ & $\begin{array}{l}0,40 \\
0,14\end{array}$ & $\begin{array}{l}0,38 \\
0,15\end{array}$ \\
\hline
\end{tabular}

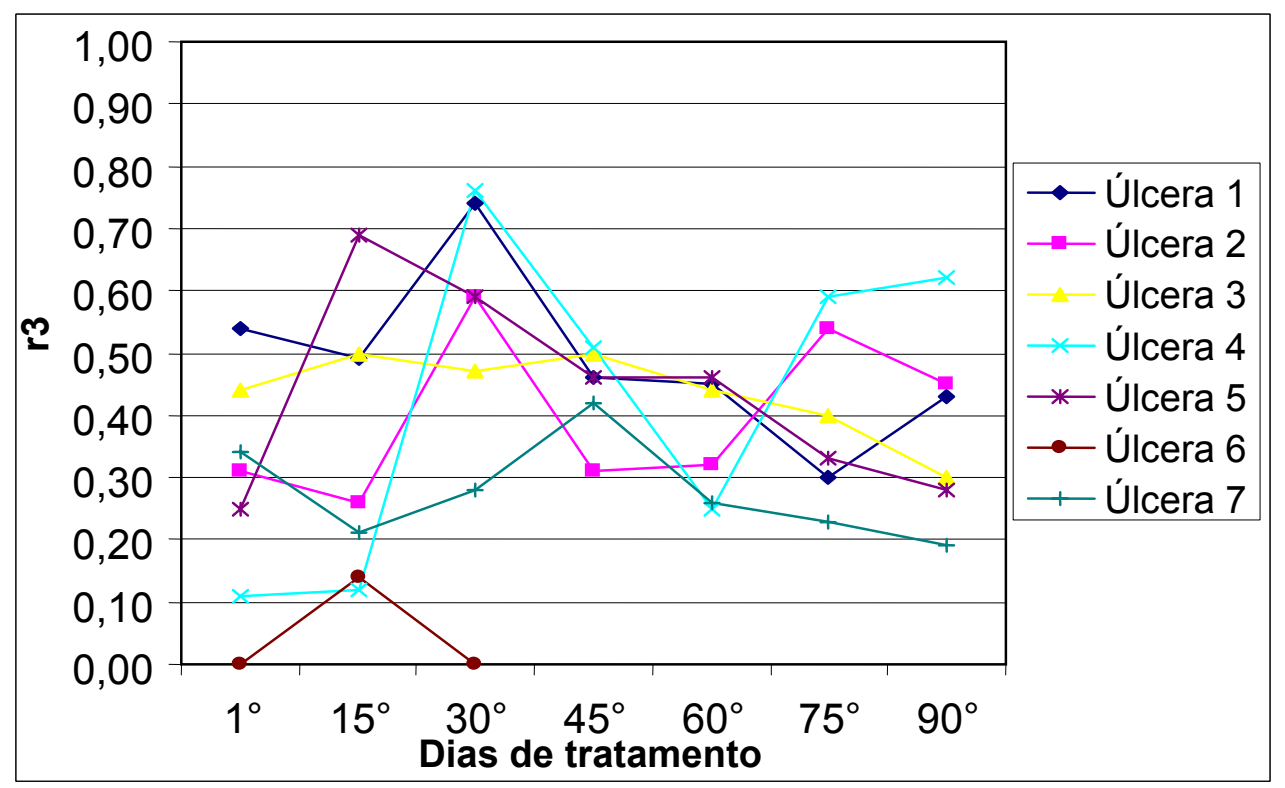

Gráfico 4.3a - Razão $r_{3}$ das úlceras do grupo 1(SDZ) 
Tabela 4.6b - Razão $r_{3}$ das úlceras do grupo 2 (US)

\begin{tabular}{|c|c|c|c|c|c|c|c|c|}
\hline Dia & $1^{\circ}$ & $15^{\circ}$ & $30^{\circ}$ & $45^{\circ}$ & $60^{\circ}$ & $75^{\circ}$ & $90^{\circ}$ & $105^{\circ}$ \\
\hline 1 & 0,41 & 0,00 & 0,34 & 0,00 & 0,00 & - & - & - \\
\hline 2 & 0,21 & 0,13 & 0,13 & 0,06 & 0,03 & 0,15 & 0,08 & 0,00 \\
\hline 3 & 0,40 & 0,37 & 0,13 & 0,00 & 0,00 & 0,00 & 0,00 & - \\
\hline 4 & 0,32 & 0,38 & 0,26 & 0,29 & 0,22 & 0,23 & 0,25 & - \\
\hline 5 & 0,64 & 0,53 & 0,50 & 0,14 & 0,30 & 0,26 & 0,34 & - \\
\hline 6 & 0,18 & 0,52 & 0,38 & 0,40 & 0,00 & - & - & - \\
\hline 7 & 0,16 & 0,17 & 0,20 & 0,09 & 0,06 & 0,15 & 0,00 & - \\
\hline 8 & 0,12 & 0,33 & 0,25 & 0,32 & 0,31 & 0,16 & 0,12 & - \\
\hline 9 & 0,16 & 0,18 & 0,05 & 0,00 & 0,12 & 0,00 & 0,00 & - \\
\hline $\begin{array}{c}\text { Média } \\
\text { Desvio Padrão }\end{array}$ & $\begin{array}{l}0,29 \\
0,17\end{array}$ & $\begin{array}{l}0,29 \\
0,18\end{array}$ & $\begin{array}{l}0,25 \\
0,14\end{array}$ & $\begin{array}{l}0,14 \\
0,15\end{array}$ & $\begin{array}{l}0,12 \\
0,13\end{array}$ & $\begin{array}{l}0,14 \\
0,10\end{array}$ & $\begin{array}{l}0,11 \\
0,14\end{array}$ & - \\
\hline
\end{tabular}

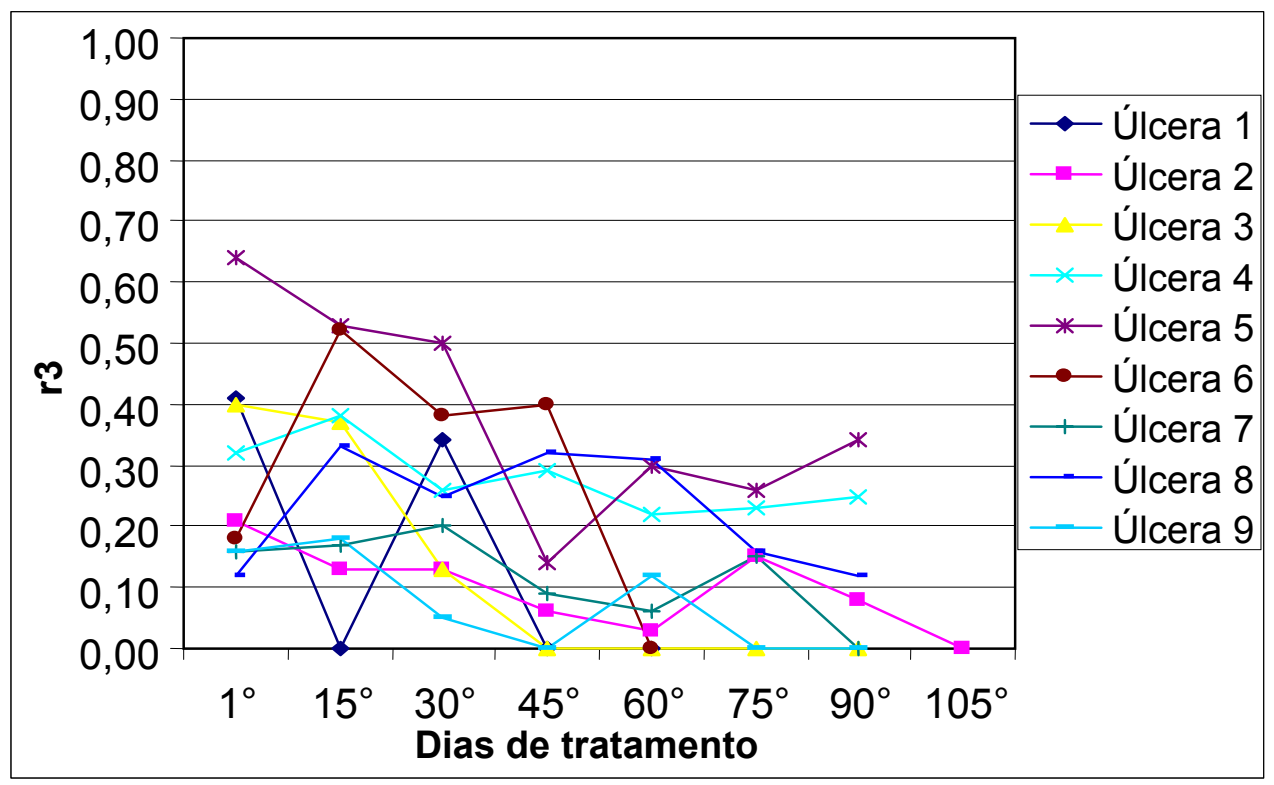

Gráfico 4.3b - Razão $r_{3}$ das úlceras do grupo 2 (US) 


\subsection{Imunohistoquímica}

Foram extraídas biópsias em 5 pacientes do Grupo 1 e em 7 pacientes do Grupo 2. Uma das biópsias do Grupo 2 não foi analisada por problemas relacionados à coleta. Dois pacientes não autorizaram a coleta da biópsia e a dimensão pequena da úlcera de três pacientes não permitiu a coleta da biópsia.

A tabela 4.7 descreve o resultado da análise imunohistoquímica.

Tabela 4.7 - Análise imunohistoquímica das biópsias das úlceras segundo a área marcada de iNOS, TGF $\beta$ e VEGF no $1^{\circ}$ dia e $45^{\circ}$ dia de tratamento nas úlceras dos pacientes do Grupo 1 (SDZ) e Grupo 2 (US).

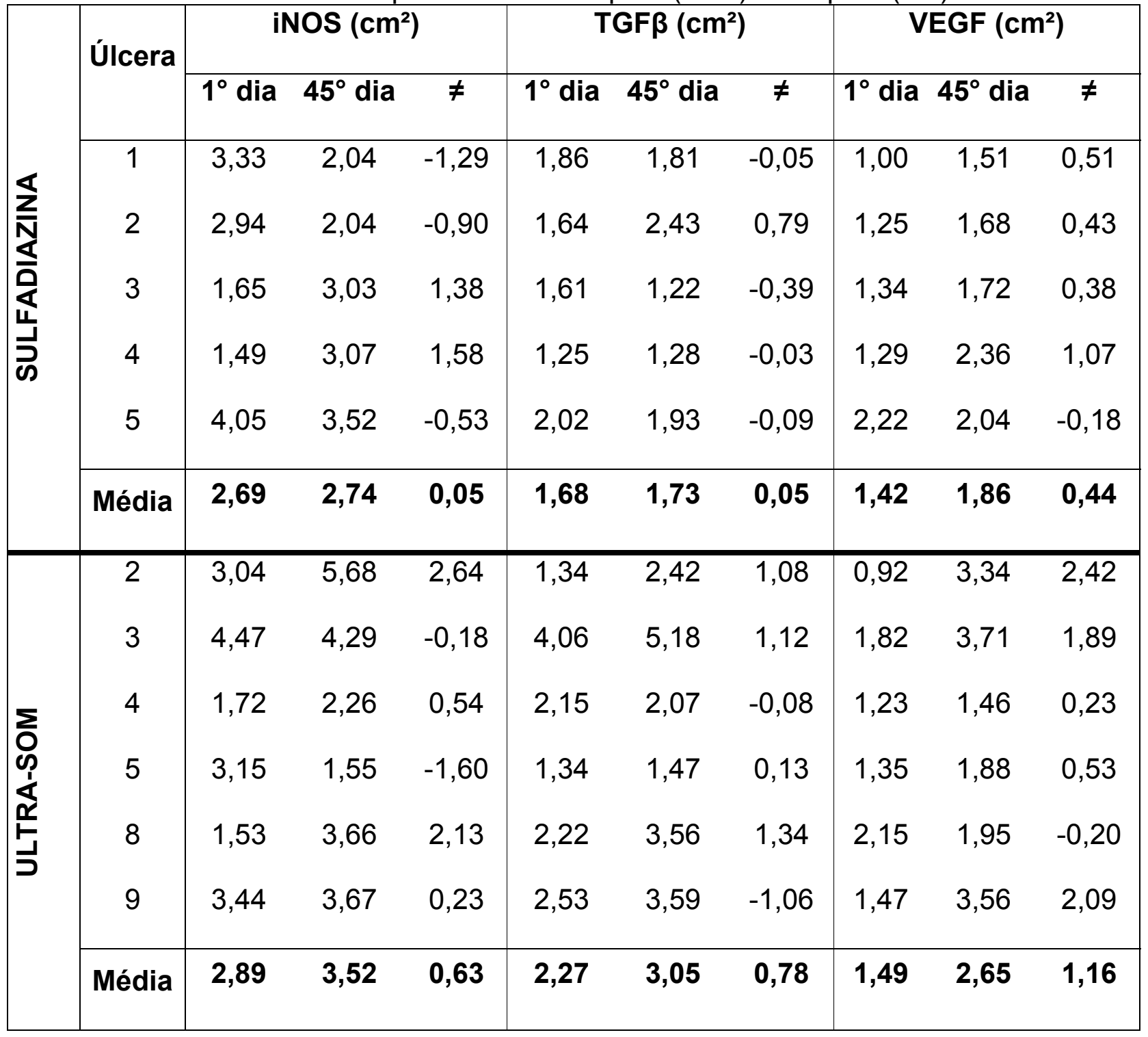




\subsection{Testes de Validação e Comparação do software Image $\mathrm{J}^{\circledR}$}

Estudo 1: validação da medida da área das úlceras através do software Image $^{\circledR}$.

A tabela 4.8 descreve os valores da massa de 10 amostras do papel milimetrado com área de $1 \mathrm{~cm}^{2}$.

Tabela 4.8 - Valor Médio da massa do papel com área padrão de $1 \mathrm{~cm}^{2}$

\begin{tabular}{|c|c|}
\hline Amostra & Massa (g) \\
\hline 1 & 0,0063 \\
\hline 2 & 0,0058 \\
\hline 3 & 0,0056 \\
\hline 4 & 0,0060 \\
\hline 5 & 0,0063 \\
\hline 6 & 0,0060 \\
\hline 7 & 0,0062 \\
\hline 8 & 0,0061 \\
\hline 9 & 0,0062 \\
\hline 10 & 0,0060 \\
\hline $\begin{array}{c}\text { Média } \\
\text { Desvio Padrão }\end{array}$ & $\begin{array}{l}\mathbf{0 , 0 0 6 1} \\
\mathbf{0 , 0 0 0 2 3}\end{array}$ \\
\hline
\end{tabular}

A tabela 4.9 descreve: a) o valor medido da massa do papel milimetrado de amostras com área regular ou irregular; b) a área das amostras medida através da razão entre a medida da massa do papel.com área regular ou irregular e a medida da média da massa do papel com área padrão; c) a área das amostras medida pelo software Image $J^{\circledR}$. 
Tabela 4.9 - Validação da Medida da Área

\begin{tabular}{|c|c|c|c|c|}
\hline Amostra & $\begin{array}{c}\text { Massa } \\
\text { (g) }\end{array}$ & $\begin{array}{c}\text { Área da } \\
\text { amostra } \\
\left(\mathrm{cm}^{2}\right) \\
(\text { balança) }\end{array}$ & $\begin{array}{c}\text { Área da } \\
\text { amostra } \\
\left(\mathrm{cm}^{2}\right) \\
\left(\text { ImageJ }^{\circledR}\right)\end{array}$ & Erro (\%) \\
\hline Irregular 1 & 0,0891 & 14,73 & 14,13 & 4,06 \\
\hline Irregular 2 & 0,0674 & 11,14 & 10,92 & 1,98 \\
\hline Irregular 3 & 0,1107 & 18,30 & 17,91 & 2,12 \\
\hline Irregular 4 & 0,2080 & 34,38 & 32.45 & 5,61 \\
\hline Irregular 5 & 0,2399 & 39,65 & 37,25 & 6,06 \\
\hline quadrado de lado $2 \mathrm{~cm}$ & 0,0257 & 4,25 & 3,9 & 8,19 \\
\hline quadrado de lado $3 \mathrm{~cm}$ & 0,0579 & 9,57 & 9,1 & 4,91 \\
\hline quadrado de lado $4 \mathrm{~cm}$ & 0,1024 & 16,93 & 16,25 & 3,99 \\
\hline quadrado de lado $5 \mathrm{~cm}$ & 0,1598 & 26,41 & 24,70 & 6,49 \\
\hline $\begin{array}{c}\text { Média } \\
\text { Desvio Padrão }\end{array}$ & - & - & - & $\begin{array}{l}4,82 \\
2,03\end{array}$ \\
\hline
\end{tabular}

Estudo 2: comparação de análises de imagem realizadas pelo software Image $J^{\circledR}$ captadas com câmara digital e com o uso de folha plástica.

A tabela 4.10 descreve os valores medidos das áreas das úlceras e dos tecidos de granulação e fibrina através do Image $J^{\circledR}$ e do uso da folha plástica.

Estudo 3: comparação entre técnica convencional de análise de imagem e a realizada pelo Image $\mathrm{J}^{\circledR}$.

A tabela 4.11 descreve os valores medidos das áreas das úlceras utilizando o software Image $J^{\circledR}$ e técnicas convencionais (aproximação por uma elipse ou por um retângulo). 
Tabela 4.10 - Comparação entre Câmara Digital e Método Manual

\begin{tabular}{|c|c|c|c|c|c|c|c|c|c|}
\hline Ulcera & $\begin{array}{c}\text { S3 (cm2) } \\
\text { Úlcera } \\
\text { (desenho) }\end{array}$ & $\begin{array}{c}\text { S4 (cm2) } \\
\text { Úlcera } \\
\text { (foto) }\end{array}$ & $\begin{array}{c}\text { S4-S3 } \\
\text { (cm2) }\end{array}$ & $\begin{array}{c}\text { S5 (cm2) } \\
\text { Granulação } \\
\text { (desenho) }\end{array}$ & $\begin{array}{c}\text { S6 (cm2) } \\
\text { Granulação } \\
\text { foto }\end{array}$ & $\begin{array}{c}\text { S6-S5 } \\
\text { (cm2) }\end{array}$ & $\begin{array}{c}\text { S7 (cm2) } \\
\text { Fibrina } \\
\text { (desenho) }\end{array}$ & $\begin{array}{c}\text { S8 (cm2) } \\
\text { Fibrina } \\
\text { (foto) }\end{array}$ & $\begin{array}{c}\text { S8-S7 } \\
\text { (cm2) }\end{array}$ \\
\hline 1 & 0,7 & 1,1 & 0,4 & 0,6 & 1,1 & 0,5 & 0,1 & 0 & 0,1 \\
\hline 2 & 2,3 & 3,1 & 0,8 & 2,3 & 3,1 & 0,8 & 0 & 0 & 0 \\
\hline 3 & 5,4 & 6 & 0,6 & 4,3 & 5,7 & 1,4 & 0,9 & 0,3 & $-0,6$ \\
\hline 4 & 0,4 & 0,8 & 0,4 & 0,2 & 0,4 & 0,2 & 0,2 & 0,4 & 0,2 \\
\hline 5 & 11,9 & 13,3 & 1,4 & 10,4 & 10,6 & 0,2 & 0,9 & 2 & 1,1 \\
\hline 6 & 7,1 & 6,8 & $-0,3$ & 5,2 & 4,8 & $-0,4$ & 1,6 & 0,6 & -1 \\
\hline 7 & 14,6 & 13 & $-1,6$ & 14,6 & 13 & $-1,6$ & 0 & 0 & 0 \\
\hline 8 & 103,9 & 136,7 & 32,8 & 103,9 & 112,7 & 8,8 & 0 & 15,6 & 15,6 \\
\hline 9 & 40,2 & 43,7 & 3,5 & 40,2 & 37,4 & $-2,8$ & 0 & 3,5 & 3,5 \\
\hline 10 & 9,6 & 9 & $-0,6$ & 6,7 & 7,9 & 1,2 & 2,4 & 0,5 & $-1,9$ \\
\hline 11 & 0,9 & 1,3 & 0,4 & 0,9 & 1,3 & 0,4 & 0 & 0 & 0 \\
\hline 12 & 18,8 & 26,2 & 7,4 & 18,4 & 24,4 & 6 & 0 & 1,7 & 1,7 \\
\hline 13 & 8,5 & 10,4 & 1,9 & 8,5 & 9,1 & 0,6 & 0 & 1,1 & 1,1 \\
\hline 14 & 43,5 & 34,4 & $-9,1$ & 43,5 & 34,4 & $-9,1$ & 0 & 0 & 0 \\
\hline 15 & 3,2 & 2,1 & $-1,1$ & 3,1 & 2,1 & -1 & 0 & 0 & 0 \\
\hline 16 & 0,8 & 0,7 & $-0,1$ & 0,6 & 0,7 & 1 & 0,1 & 0 & $-0,1$ \\
\hline 17 & 0,6 & 0,6 & 0 & 0,6 & 0,4 & $-0,2$ & 0 & 0,2 & 0,2 \\
\hline 18 & 33,6 & 31,6 & -2 & 32,6 & 31,1 & $-1,5$ & 0,4 & 0,5 & 0,1 \\
\hline 19 & 20,7 & 19,8 & $-0,9$ & 16,3 & 17,1 & 0,8 & 3,9 & 2,7 & $-1,2$ \\
\hline 20 & 18,8 & 23,2 & 4,4 & 15,8 & 16,5 & 0,7 & 2 & 4,1 & 2,1 \\
\hline 21 & 1,6 & 1,6 & 0 & 0,5 & 1 & 0,5 & 0,9 & 0,3 & $-0,6$ \\
\hline 22 & 5,8 & 7,1 & 1,3 & 4 & 4,5 & 0,5 & 1,3 & 2 & 0,7 \\
\hline 23 & 1,1 & 1,3 & 0,2 & 0,4 & 0,5 & 0,1 & 0,5 & 0,4 & $-0,1$ \\
\hline 24 & 23 & 25,8 & 2,8 & 18,2 & 19,7 & 1,5 & 3,8 & 5,9 & 2,1 \\
\hline 25 & 13,7 & 12,9 & $-0,8$ & 13,7 & 12,9 & $-0,8$ & 0 & 0 & 0 \\
\hline Média & $\mathbf{1 5 , 6 3}$ & $\mathbf{1 7 , 3 0}$ & $\mathbf{1 , 6 7}$ & $\mathbf{1 4 , 6 2}$ & $\mathbf{1 4 , 9 0}$ & $\mathbf{0 , 3 1}$ & $\mathbf{0 , 7 6}$ & $\mathbf{1 , 6 7}$ & $\mathbf{0 , 9}$ \\
\hline
\end{tabular}

Tabela 4.11 - Comparação entre Técnica Convencional e Image $J^{\circledR}$

\begin{tabular}{|c|c|c|c|c|c|c|}
\hline Ulcera & $\begin{array}{c}\text { Área (cm2) } \\
\text { da Úlcera } \\
\text { (ImageJ) }\end{array}$ & $\begin{array}{c}\text { Área (cm2) } \\
\text { Papel } \\
\text { centimetrado }\end{array}$ & $\begin{array}{c}\text { Úlcera } \\
\text { Eixo transversal } \\
\text { da Úlcera (cm) }\end{array}$ & $\begin{array}{c}\text { Úlcera } \\
\text { Eixo longitudinal } \\
\text { da Úlcera (cm) }\end{array}$ & $\begin{array}{c}\text { Área (cm2) } \\
\text { da Úlcera } \\
\text { (Elipse) }\end{array}$ & $\begin{array}{c}\text { Área (cm2) } \\
\text { da Úlcera } \\
\text { (Retângulo) }\end{array}$ \\
\hline 1 & 1,1 & 1 & 1,1 & 0,8 & 0,7 & 0,9 \\
\hline 2 & 3,1 & 3 & 1,7 & 1,5 & 2,0 & 2,6 \\
\hline 3 & 6 & 7 & 2,4 & 2,6 & 4,9 & 6,2 \\
\hline 4 & 0,8 & 0,5 & 0,5 & 0,7 & 0,3 & 0,4 \\
\hline 5 & 13,3 & 15 & 2,9 & 5,1 & 11,6 & 14,8 \\
\hline 6 & 6,8 & 6 & 2,7 & 3,2 & 6,8 & 8,6 \\
\hline 7 & 13 & 11 & 5,7 & 4,2 & 18,8 & 23,9 \\
\hline 8 & 136,7 & 48 & 15,2 & 9,5 & 113,4 & 144,4 \\
\hline 9 & 43,7 & 30 & 7,7 & 5,8 & 35,1 & 44,7 \\
\hline 10 & 9 & 7 & 4,4 & 2,7 & 9,3 & 11,9 \\
\hline 11 & 1,3 & 1 & 1 & 0,9 & 0,7 & 0,9 \\
\hline 12 & 26,2 & 15 & 4 & 4,6 & 14,5 & 18,4 \\
\hline 13 & 10,4 & 7 & 4,5 & 2,4 & 8,5 & 10,8 \\
\hline 14 & 34,4 & 33 & 10,6 & 6,2 & 51,6 & 65,7 \\
\hline 15 & 2,1 & 4 & 2 & 1,9 & 3,0 & 3,8 \\
\hline 16 & 0,7 & 1 & 0,8 & 1,1 & 0,7 & 0,9 \\
\hline 17 & 0,6 & 1 & 0,9 & 0,8 & 0,6 & 0,7 \\
\hline 18 & 31,6 & 43 & 7,4 & 6,1 & 35,5 & 45,1 \\
\hline 19 & 19,8 & 25 & 5,7 & 6,1 & 27,3 & 34,8 \\
\hline 20 & 23,2 & 23 & 7,4 & 3,2 & 18,6 & 23,7 \\
\hline 21 & 1,6 & 2 & 1,1 & 1,9 & 1,6 & 2,1 \\
\hline 22 & 7,1 & 7 & 2,1 & 4,6 & 7,6 & 9,7 \\
\hline 23 & 1,3 & 1 & 0,9 & 1,2 & 0,8 & 1,1 \\
\hline 24 & 25,8 & 18 & 7,7 & 3,8 & 23,0 & 29,3 \\
\hline 25 & 12,9 & 10 & 4,7 & 3,5 & 12,9 & 16,5 \\
\hline Média & $\mathbf{1 7 , 3}$ & $\mathbf{1 2 , 7 8}$ & $\mathbf{1 7 , 3}$ & $\mathbf{1 7 , 3}$ & $\mathbf{1 6 , 4}$ & $\mathbf{2 0 , 9}$ \\
\hline & & & & & & \\
\hline
\end{tabular}


Estudo 4: influência da captura de imagem através de método não padronizado e padronizado na análise de imagem.

A tabela 4.12 descreve as medidas de área das úlceras, do tecido de granulação e de fibrina utilizando os métodos não padronizado e padronizado de captura da imagem.

Tabela 4.12 - Comparação entre método padronizado e não padronizado

\begin{tabular}{|c|c|c|c|c|c|c|}
\hline \multicolumn{4}{|c|}{ Padronizada } & \multicolumn{3}{|c|}{ Não Padronizada } \\
\hline Ulcera & $\begin{array}{c}\text { Área (cm2) } \\
\text { Úlcera }\end{array}$ & $\begin{array}{l}\text { Área (cm2) } \\
\text { Tecido de } \\
\text { Granulação }\end{array}$ & $\begin{array}{c}\text { Área (cm2) } \\
\text { Tecido de } \\
\text { Fribrina }\end{array}$ & $\begin{array}{l}\text { Área (cm2) } \\
\text { Úlcera }\end{array}$ & $\begin{array}{l}\text { Área (cm2) } \\
\text { Tecido de } \\
\text { Granulação }\end{array}$ & $\begin{array}{c}\text { Área (cm2) } \\
\text { Tecido de } \\
\text { Fribrina }\end{array}$ \\
\hline 1 & 15,7 & 8,2 & 0,8 & 12,9 & 10,4 & 0,6 \\
\hline 2 & 18,2 & 8,6 & 2,4 & 15,1 & 13 & 1,9 \\
\hline 3 & 66,5 & 56,5 & 7,8 & 44,8 & 27,6 & 16 \\
\hline 4 & 13,6 & 10,7 & 2,5 & 9,6 & 6,9 & 2,3 \\
\hline 5 & 14,2 & 7,6 & 6,6 & 10,2 & 3,9 & 5,1 \\
\hline 6 & 63,1 & 43,6 & 19,4 & 71,5 & 29,5 & 29,9 \\
\hline 7 & 30,5 & 20,1 & 6,9 & 35,4 & 12 & 23,4 \\
\hline 8 & 31,9 & 18,9 & 10,1 & 37,4 & 5,2 & 30,3 \\
\hline 9 & 16,6 & 5,8 & 7,5 & 20,2 & 4,9 & 12,6 \\
\hline 10 & 30 & 23,5 & 4,2 & 25,1 & 15 & 6,6 \\
\hline 11 & 20 & 12,6 & 5,7 & 12,7 & 5,4 & 7,3 \\
\hline 12 & 12,7 & 10,1 & 1,5 & 13,4 & 10,9 & 1,5 \\
\hline 13 & 9,8 & 8 & 1,3 & 8,2 & 5,6 & 1 \\
\hline 14 & 6 & 0 & 6 & 5,3 & 0 & 5,3 \\
\hline 15 & 8,5 & 5,1 & 3 & 10,5 & 5,4 & 4,9 \\
\hline 16 & 10,5 & 8,2 & 2,3 & 9,1 & 5,3 & 1,6 \\
\hline 17 & 8,8 & 6,6 & 0,7 & 7 & 4,8 & 0,8 \\
\hline 18 & 9,3 & 0 & 9,3 & 5,7 & 0 & 5,7 \\
\hline 19 & 7 & 0 & 7 & 7 & 0 & 7 \\
\hline 20 & 7 & 4,9 & 2,1 & 7,9 & 5,1 & 2,7 \\
\hline 21 & 9,7 & 7,8 & 1,9 & 10,6 & 6,1 & 2 \\
\hline 22 & 8 & 3,8 & 4,1 & 8,5 & 3,9 & 4,2 \\
\hline 23 & 2,4 & $\overline{1,4}$ & 0,8 & $\overline{4,1}$ & 2,3 & 2 \\
\hline 24 & 1,1 & 1,1 & 0 & 1,3 & 1,3 & 0 \\
\hline 25 & 0,3 & 0,3 & 0 & 0,4 & 0,4 & 0 \\
\hline 26 & 1,5 & 0,7 & 0,5 & 1,8 & 0,7 & 0,9 \\
\hline 27 & 1,1 & 1 & 0,1 & 1,1 & 0,9 & 0,1 \\
\hline 28 & 2,6 & 2 & 0,6 & 2,3 & 1,3 & 0,6 \\
\hline 29 & 3,4 & 2,1 & 1,3 & 2,9 & 1,1 & 1,8 \\
\hline 30 & 2,2 & 1,8 & 0,4 & 1,9 & 1,3 & 0,6 \\
\hline Média & 14,41 & 9,37 & 3,89 & 13,46 & 6,34 & 5,96 \\
\hline
\end{tabular}

Estudo 5: influência humana na segmentação manual da borda da úlcera e dos tecidos de granulação e fibrina realizada através de mouse na análise de imagem.

A tabela 4.13 descreve a influência humana no uso do software Image ${ }^{\circledR}$. 
Tabela 4.13 - Influência Humana no uso do Software ImageJ ${ }^{\circledR}$

\begin{tabular}{|c|c|c|c|c|c|c|}
\hline \multirow[b]{2}{*}{ Úlcera } & \multicolumn{3}{|c|}{ Usuário 1} & \multicolumn{3}{|c|}{ Usuário 2} \\
\hline & $\begin{array}{l}\text { Área }(\mathrm{cm} 2) \\
\text { Úlcera }\end{array}$ & $\begin{array}{l}\text { Área (cm2) } \\
\text { Granulação }\end{array}$ & $\begin{array}{l}\text { Área (cm2) } \\
\text { Fibrina }\end{array}$ & $\begin{array}{c}\text { Área (cm2) } \\
\text { Úlcera }\end{array}$ & $\begin{array}{l}\text { Área (cm2) } \\
\text { Granulação }\end{array}$ & $\begin{array}{c}\text { Área (cm2) } \\
\text { Fibrina }\end{array}$ \\
\hline 1 & 17,00 & 12,20 & 3,50 & 18,10 & 13,30 & 3,60 \\
\hline 2 & 19,90 & 9,80 & 9,30 & 15,70 & 7,80 & 6,80 \\
\hline 3 & 18,60 & 13,70 & 4,30 & 16,20 & 10,40 & 5,80 \\
\hline 4 & 16,00 & 12,10 & 2,40 & 14,50 & 12,30 & 1,30 \\
\hline 5 & 15,10 & 13,10 & 2,00 & 15,00 & 12,70 & 2,30 \\
\hline 6 & 14,10 & 12,20 & 1,50 & 13,20 & 13,20 & 0,00 \\
\hline 7 & 14,30 & 13,60 & 0,70 & 12,90 & 12,90 & 0,00 \\
\hline 8 & 31,70 & 24,70 & 6,90 & 31,90 & 18,90 & 10,10 \\
\hline 9 & 32,40 & 25,70 & 6,40 & 38,00 & 23,40 & 14,60 \\
\hline 10 & 34,10 & 25,50 & 8,00 & 34,60 & 25,60 & 9,00 \\
\hline 11 & 14,30 & 14,30 & 0,00 & 15,10 & 12,50 & 2,60 \\
\hline 12 & 16,00 & 16,00 & 0,00 & 17,60 & 12,80 & 3,90 \\
\hline 13 & 1,60 & 0,90 & 0,60 & 1,20 & 0,60 & 0,60 \\
\hline 14 & 1,40 & 0,80 & 0,50 & 0,80 & 0,50 & 0,30 \\
\hline 15 & 0,70 & 0,50 & 0,20 & 0,60 & 0,40 & 0,20 \\
\hline Média & 16,48 & 13,01 & 3,09 & 16,36 & 11,82 & 4,07 \\
\hline
\end{tabular}

\subsection{Resultados Estatísticos}

A análise estatística dos resultados experimentais foi realizada com o teste não paramétrico de Mann-Whitney, com nível de significância de $5 \%$. As análises foram realizadas incluindo e não incluindo as úlceras com área menor que $1,5 \mathrm{~cm}^{2}$. 
A tabela 4.14 descreve os resultados estatísticos da comparação entre as úlceras dos grupos experimentais para os seguintes parâmetros:

- $\quad$ Áreas das ulceras do grupo 1 e do grupo 2 no $30^{\circ}$ e $60^{\circ}$ dia

- $\quad$ Razão $r_{1}$ das úlceras de perna no $90^{\circ}$ dia

- $\quad$ Razão entre tecido de granulação e área total das úlceras no $1^{\circ}, 15^{\circ}, 30^{\circ}, 45^{\circ}$, $60^{\circ}, 75^{\circ}$ e $90^{\circ}$ dias.

- $\quad$ Razão entre tecido de fibrina e área total das úlceras no $1^{\circ}, 15^{\circ}, 30^{\circ}, 45^{\circ}, 60^{\circ}$, $75^{\circ}$ e $90^{\circ}$ dias.

A homogeneidade entre os grupos experimentais foi avaliada através da análise estatística dos seguintes parâmetros:

- $\quad$ área das úlceras de perna no $1^{0} \mathrm{dia}$

- $\quad$ razão entre tecido de granulação e área total no $1^{\circ}$ dia

- $\quad$ razão entre tecido de fibrina e área total no $1^{\circ}$ dia

A tabela 4.14 mostra que esses parâmetros não são estatisticamente diferentes e que, portanto, os grupos eram homogêneos.

Houve diferença estatística nas seguintes comparações:

- $\quad$ razão $r_{1}$ das úlceras de perna no $90^{\circ}$ dia

- $\quad$ razão entre tecido de granulação e área total no $30^{\circ}, 45^{\circ}, 60^{\circ}, 75^{\circ}, 90^{\circ}$ dias não incluindo as úlceras com área menor que $1,5 \mathrm{~cm}^{2}$.

- $\quad$ razão entre tecido de fibrina e área total no $30^{\circ}, 45^{\circ}, 75^{\circ}, 90^{\circ}$ dias não incluindo as úlceras com área menor que $1,5 \mathrm{~cm}^{2}$.

A tabela 4.15 descreve os resultados estatísticos da comparação entre as úlceras dos grupos experimentais para os seguintes parâmetros:

- $\quad$ célula marcada pela enzima iNOS no $1^{\circ}$ e $45^{\circ}$ dia.

- $\quad$ célula marcada pelos fatores de crescimento TGFB e VEGF no $1^{\circ}$ e $45^{\circ}$ dia. 
Não houve diferença estatística nas quantificações dos parâmetros acima descritos.

Tabela 4.14 - Resultado Estatístico da Análise das Áreas das Ulceras Teste Mann-Whitney $(\alpha=0,05)$

Teste A: incluindo as úlceras com área $<1,5 \mathrm{~cm}^{2}\left(\mathrm{n}_{1}=7, \mathrm{n}_{2}=9\right.$, Ucritico=51)

Teste B: não incluindo as úlceras com área $<1,5 \mathrm{~cm}^{2}\left(\mathrm{n}_{1}=6, \mathrm{n}_{2}=7\right.$, Ucritico $\left.=36\right)$

\begin{tabular}{|c|c|c|c|c|c|c|}
\hline & \multicolumn{3}{|c|}{ Teste A } & \multicolumn{3}{|c|}{ Teste B } \\
\hline & $\begin{array}{c}\text { Média } \\
\text { Grupo } 1 \\
\text { Grupo } 2\end{array}$ & U calculado & rejeição & $\begin{array}{c}\text { Média } \\
\text { Grupo } 1 \\
\text { Grupo } 2\end{array}$ & U calculado & rejeição \\
\hline $\begin{array}{c}\text { Áreas das ulceras } \\
\text { no } 1^{\circ} \text { dia }\end{array}$ & $\begin{array}{l}28,23 \\
10,03\end{array}$ & 39 & não & $\begin{array}{l}32,78 \\
13,75\end{array}$ & 25 & não \\
\hline $\begin{array}{c}\text { Áreas das ulceras } \\
\text { no } 30^{\circ} \text { dia }\end{array}$ & $\begin{array}{l}33,05 \\
18,83\end{array}$ & 37 & não & $\begin{array}{l}38,56 \\
24,05\end{array}$ & 25 & não \\
\hline $\begin{array}{c}\text { Áreas das ulceras } \\
\text { no } 60^{\circ} \text { dia }\end{array}$ & $\begin{array}{l}28,38 \\
16,87\end{array}$ & 39 & não & $\begin{array}{l}33,11 \\
21,69\end{array}$ & 22 & não \\
\hline $\begin{array}{c}\text { Razão } r_{1} \text { das } \\
\text { úlceras no } 90^{\circ} \text { dia }\end{array}$ & $\begin{array}{c}-0,03 \\
0,41\end{array}$ & 51 & $\operatorname{sim}$ & $\begin{array}{c}-0,20 \\
0,24\end{array}$ & 38 & $\operatorname{sim}$ \\
\hline $\begin{array}{c}\text { Razão } \mathrm{r}_{2} \text { das } \\
\text { úlceras no } 1^{\circ} \mathrm{dia}\end{array}$ & $\begin{array}{l}0,70 \\
0,71\end{array}$ & 39 & não & $\begin{array}{l}0,66 \\
0,67\end{array}$ & 25 & não \\
\hline $\begin{array}{c}\text { Razão } r_{2} \text { das } \\
\text { úlceras no } 15^{\circ} \text { dia }\end{array}$ & $\begin{array}{l}0,64 \\
0,67\end{array}$ & 34 & não & $\begin{array}{l}0,61 \\
0,68\end{array}$ & 25 & não \\
\hline $\begin{array}{c}\text { Razão } r_{2} \text { das } \\
\text { úlceras no } 30^{\circ} \text { dia }\end{array}$ & $\begin{array}{l}0,37 \\
0,77\end{array}$ & 50 & não & $\begin{array}{l}0,43 \\
0,76\end{array}$ & 40 & $\operatorname{sim}$ \\
\hline $\begin{array}{c}\text { Razão } r_{2} \text { das } \\
\text { úlceras no } 45^{\circ} \text { dia }\end{array}$ & $\begin{array}{l}0,48 \\
0,85\end{array}$ & 34 & não & $\begin{array}{l}0,56 \\
0,85\end{array}$ & 41 & $\operatorname{sim}$ \\
\hline $\begin{array}{c}\text { Razão } r_{2} \text { das } \\
\text { úlceras no } 60^{\circ} \text { dia }\end{array}$ & $\begin{array}{l}0,54 \\
0,62\end{array}$ & 50 & não & $\begin{array}{l}0,63 \\
0,80\end{array}$ & 38 & $\operatorname{sim}$ \\
\hline $\begin{array}{c}\text { Razão } r_{2} \text { das } \\
\text { úlceras no } 75^{\circ} \text { dia }\end{array}$ & $\begin{array}{l}0,51 \\
0,66\end{array}$ & 51 & $\operatorname{sim}$ & $\begin{array}{l}0,59 \\
0,85\end{array}$ & 40,5 & $\operatorname{sim}$ \\
\hline $\begin{array}{c}\text { Razão } r_{2} \text { das } \\
\text { úlceras no } 90^{\circ} \text { dia }\end{array}$ & $\begin{array}{l}0,53 \\
0,68\end{array}$ & 50 & não & $\begin{array}{l}0,62 \\
0,88\end{array}$ & 38 & $\operatorname{sim}$ \\
\hline $\begin{array}{c}\text { Razão } r_{3} \text { das } \\
\text { úlceras no } 10 \text { dia }\end{array}$ & $\begin{array}{l}0,28 \\
0,29\end{array}$ & 31 & não & $\begin{array}{l}0,33 \\
0,29\end{array}$ & 23 & não \\
\hline $\begin{array}{l}\text { Razão } r_{3} \text { das } \\
\text { úlceras no } 15^{\circ} \text { dia }\end{array}$ & $\begin{array}{l}0,34 \\
0,29\end{array}$ & 32,5 & não & $\begin{array}{l}0,38 \\
0,30\end{array}$ & 25,5 & não \\
\hline $\begin{array}{c}\text { Razão } r_{3} \text { das } \\
\text { úlceras no } 30^{\circ} \text { dia }\end{array}$ & $\begin{array}{l}0,49 \\
0,25\end{array}$ & 59 & $\operatorname{sim}$ & $\begin{array}{l}0,57 \\
0,22\end{array}$ & 39 & $\operatorname{sim}$ \\
\hline $\begin{array}{c}\text { Razão } r_{3} \text { das } \\
\text { úlceras no } 45^{\circ} \text { dia }\end{array}$ & $\begin{array}{l}0,38 \\
0,14\end{array}$ & 70 & sim & $\begin{array}{l}0,44 \\
0,13\end{array}$ & 42 & $\operatorname{sim}$ \\
\hline $\begin{array}{c}\text { Razão } r_{3} \text { das } \\
\text { úlceras no } 60^{\circ} \text { dia }\end{array}$ & $\begin{array}{l}0,31 \\
0,12\end{array}$ & 54 & $\operatorname{sim}$ & $\begin{array}{l}0,36 \\
0,15\end{array}$ & 33 & não \\
\hline $\begin{array}{c}\text { Razão } r_{3} \text { das } \\
\text { úlceras no } 75^{\circ} \text { dia }\end{array}$ & $\begin{array}{l}0,34 \\
0,11\end{array}$ & 60 & $\operatorname{sim}$ & $\begin{array}{l}0,40 \\
0,14\end{array}$ & 42 & $\operatorname{sim}$ \\
\hline $\begin{array}{c}\text { Razão } r_{3} \text { das } \\
\text { úlceras no } 90^{\circ} \text { dia }\end{array}$ & $\begin{array}{l}0,32 \\
0,09\end{array}$ & 58,5 & $\operatorname{sim}$ & $\begin{array}{l}0,38 \\
0,11 \\
\end{array}$ & 38,5 & sim \\
\hline
\end{tabular}


Tabela 4.15 - Resultados Estatísticos da Análise da Imunohistoquímica Teste Mann-Whitney $\left(\alpha=0,05, \mathrm{n}_{1}=5, \mathrm{n}_{2}=6\right.$, Ucritico=27)

\begin{tabular}{|c|c|c|c|}
\hline & $\begin{array}{c}\text { Média } \\
\text { Grupo } 1 \\
\text { Grupo } 2\end{array}$ & U calculado & rejeição \\
\hline iNOS_1 ${ }^{0}$ dia & $\begin{array}{l}2,69 \\
2,89\end{array}$ & 18 & não \\
\hline iNOS_ $45^{\circ} \mathrm{dia}$ & $\begin{array}{l}2,74 \\
3,52\end{array}$ & 24 & não \\
\hline TGFB_1 $^{\circ}$ dia & $\begin{array}{l}1,68 \\
2,27\end{array}$ & 22 & não \\
\hline TGFB_ $45^{\circ} \mathrm{dia}$ & $\begin{array}{l}1,73 \\
3,05\end{array}$ & 25 & não \\
\hline VEGF_1 ${ }^{\circ}$ dia & $\begin{array}{l}1,42 \\
1,49\end{array}$ & 17 & não \\
\hline VEGF_45 $45^{\circ} \mathrm{dia}$ & $\begin{array}{l}1,86 \\
2,65\end{array}$ & 21 & não \\
\hline
\end{tabular}

As tabelas 4.16 a 4.18 descrevem os resultados estatísticos dos estudos de 1 a 5 sobre validação e comparação do software Image $J^{\circledR}$. 
Tabela 4.16 - Estudos 1 a 3

Resultados Estatísticos - Teste Mann-Whitney $(\alpha=0,05)$

\begin{tabular}{|c|c|c|c|c|c|c|}
\hline Estudo & $\begin{array}{c}\text { Média } \\
\text { das } \\
\text { Áreas } \\
\left(\mathrm{cm}^{2}\right)\end{array}$ & $\begin{array}{c}\text { Ucritico } \\
\mathrm{n} 1=5, \mathrm{n} 2=5\end{array}$ & Umedido & $\begin{array}{c}\text { Zcritico } \\
n 1=25, n 2=25\end{array}$ & Zmedido & rejeição \\
\hline $\begin{array}{c}1 \\
\text { Área da Úlcera } \\
\text { (massa) } \\
\text { Área da Úlcera } \\
\quad\left(\text { Image }{ }^{\circledR}\right)\end{array}$ & $\begin{array}{l}19,48 \\
18,51\end{array}$ & 64 & 36 & - & - & não \\
\hline $\begin{array}{c}2 \\
\text { Área da Úlcera } \\
\text { (desenho) } \\
\text { Área da Úlcera } \\
\text { (foto) }\end{array}$ & $\begin{array}{l}15,63 \\
17,30\end{array}$ & - & - & 1,96 & 0,27 & não \\
\hline $\begin{array}{c}2 \\
\text { Área de Granulação } \\
\text { (desenho) } \\
\text { Área de Granulação } \\
\text { (foto) }\end{array}$ & $\begin{array}{l}14,62 \\
14,90\end{array}$ & - & - & 1,96 & 0,21 & não \\
\hline $\begin{array}{c}2 \\
\text { Área de Fibrina } \\
\text { (desenho) } \\
\text { Área de Fibrina } \\
\text { (foto) }\end{array}$ & $\begin{array}{l}0,76 \\
1,67\end{array}$ & - & - & 1,96 & 2,94 & $\operatorname{sim}$ \\
\hline $\begin{array}{c}3 \\
\text { Área da Úlcera } \\
\left(\text { Image }{ }^{\circledR}\right) \\
\text { Área da Úlcera } \\
\text { (papel) }\end{array}$ & $\begin{array}{l}17,30 \\
12,78\end{array}$ & - & - & 1,96 & 0,28 & não \\
\hline $\begin{array}{c}3 \\
\text { Área da Úlcera } \\
\left(\text { Image }{ }^{\circledR}\right) \\
\text { Área da Úlcera } \\
\text { (elipse) }\end{array}$ & $\begin{array}{l}17,30 \\
16,39\end{array}$ & - & - & 1,96 & 0,27 & não \\
\hline $\begin{array}{c}3 \\
\text { Área da Úlcera } \\
\left(\text { ImageJ }{ }^{\circledR}\right) \\
\text { Área da Úlcera } \\
\text { (retângulo) }\end{array}$ & $\begin{array}{l}17,30 \\
20.88\end{array}$ & - & - & 1,96 & 0,36 & não \\
\hline
\end{tabular}


Tabela 4.17 - Estudo 4

Resultados Estatísticos - Teste Mann-Whitney $(\alpha=0,05)$

\begin{tabular}{|c|c|c|c|c|c|c|}
\hline Estudo & $\begin{array}{c}\text { Média } \\
\text { das } \\
\text { Áreas } \\
\left(\mathrm{cm}^{2}\right)\end{array}$ & $\begin{array}{c}U_{\text {critico }} \\
n 1=5, n 2=5\end{array}$ & $\mathbf{U}_{\text {medido }}$ & $\begin{array}{c}Z_{\text {critico }} \\
\mathrm{n} 1=30, \mathrm{n} 2=30\end{array}$ & $\mathbf{Z}_{\text {medido }}$ & Rejeição \\
\hline $\begin{array}{c}\text { Área da Úlcera } \\
\text { (padronizada) } \\
\text { Área da Úlcera } \\
\text { (não padronizada) }\end{array}$ & $\begin{array}{l}14,41 \\
13,46 \\
\end{array}$ & - & - & 1,96 & 0,30 & não \\
\hline $\begin{array}{l}\text { Área de Granulação } \\
\text { (padronizada) } \\
\text { Área de Granulação } \\
\text { (não padronizada) }\end{array}$ & $\begin{array}{l}9,37 \\
6,34\end{array}$ & - & - & 1,96 & 0,67 & não \\
\hline $\begin{array}{l}\text { Área de Fibrina } \\
\text { (padronizada) } \\
\text { Área de Fibrina } \\
\text { (não padronizada) }\end{array}$ & $\begin{array}{l}3,89 \\
5,96\end{array}$ & - & - & 1,96 & 1,06 & não \\
\hline
\end{tabular}

Tabela 4.18 - Estudo 5

Resultados Estatísticos

Teste Mann-Whitney $\left(\alpha=0,05, \mathrm{n}_{1}=15, \mathrm{n}_{2}=15\right.$, Ucritico=161)

\begin{tabular}{|c|c|cc|}
\hline Área $\left(\mathbf{c m}^{\mathbf{2}}\right)$ & $\begin{array}{c}\text { Média } \\
\text { Pesquisador 1 } \\
\text { Pesquisador 2 }\end{array}$ & $\begin{array}{c}\mathbf{U} \\
\text { calculado }\end{array}$ & rejeição \\
\hline Úlcera & 16,48 & 119,5 & não \\
& 16,36 & & não \\
\hline Granulação & 13,01 & 127,5 & não \\
& 11,82 & & \\
\hline Fibrina & 3,09 & 125 & \\
& 4,07 & & \\
\hline
\end{tabular}


5. Discussão 
Foi observado que o uso de uma película de látex (preservativo) envolvendo o cabeçote do transdutor de ultra-som para evitar a transmissão de inúmeros patógenos promoveu uma atenuação de $11 \%$ da potência, necessitando assim uma calibração prévia do aparelho objetivando uma potência de $30 \mathrm{mw} / \mathrm{cm}^{2}$.

O monitoramento fotográfico é usado no acompanhamento e ilustração dos diferentes graus de gravidade das lesões de pele. Fotografias digitais têm sido um método padrão para documentação dos resultados em práticas cirúrgicas dermatológicas (COENRAADS, et al 2005; RATNER, 2000).

Benson et al (2005) utilizaram imagens fotográficas para o acompanhamento de tratamento dentário com a utilização do software Image Pro-Plus. Nesse estudo os autores se preocuparam em diminuir o reflexo produzido na fotografia com o auxílio de aparatos específicos, demonstrando que ele influencia nos resultados da análise de imagem e que, portanto, há necessidade de padronização na captura de imagem.

O processo de medida da área de uma úlcera é ainda predominantemente visual (qualitativo) e subjetivo devido às dificuldades em mensurar suas áreas e modificações teciduais. O monitoramento evolutivo de úlceras de pele apresenta desafios (MEDEIROS, 2001).

O uso do software Image $J^{\circledR}$ tem sido citado para a mensuração de imagens (SHIRATORI, et al. 2005) mas não há relatos do seu uso para a medida de áreas de úlceras de pele e nem mesmo dos seus diferentes tecidos. O monitoramento da úlcera pode ser baseado na área ulcerada e na profundidade, sendo este um parâmetro de difícil quantificação por envolver 3 dimensões. A profundidade não foi avaliada nesse estudo. Adicionalmente, de acordo com o dinamismo do processo de cicatrização, a evolução das úlceras pode ser acompanhada através das 
modificações teciduais de granulação e fibrina (BERRIS, 2000).

$\mathrm{Na}$ validação de medida de área através do software Image $^{\circledR}$, utilizando áreas com formato irregular e regulares, foi constatado um erro médio não significante estatisticamente de 4,82\%. A causa desse erro é desconhecida, mas não afetou a comparação da eficiência do tratamento de úlceras com SDZ e US, pois o software foi utilizado na análise das imagens das úlceras de ambos os grupos experimentais. Não foram observadas diferenças estatísticas significantes na comparação entre o uso do $\operatorname{Image} J^{\circledR}$ e técnicas manuais de monitoramento do tratamento de úlceras, bem como entre procedimento padronizado e não padronizado de captura das imagens. O procedimento manual de segmentação das imagens das úlceras através de mouse não é afetado pelo usuário do software. $\mathrm{O}$ monitoramento do tratamento de úlceras através de software de processamento de imagem facilita a determinação dos vários parâmetros que caracterizam a cicatrização e permite um registro visual e computadorizado dos mesmos.

Não houve diferença estatística entre as áreas das úlceras de perna, entre as áreas de fibrina e de granulação do grupo 1 (SDZ) e do grupo 2 (US) no $1^{0}$ dia de tratamento, caracterizando que havia homogeneidade entre os grupos experimentais no início do tratamento.

Observando as áreas das úlceras nas tabelas 4.3a e 4.3b, pode-se notar que no grupo 1 a maioria das úlceras tiveram diminuição da razão $r_{1}$ de cicatrização seguido por um aumento, chegando ao fim do tratamento com as dimensões maiores quando comparadas ao $1^{\circ}$ dia. No grupo 2, em algumas úlceras, ocorreu inicialmente uma diminuição da razão $r_{1}$ de cicatrização mas após o $30^{\circ}$ dia houve um aumento das mesmas. Os resultados mostraram que tanto o tratamento com SDZ quanto com US, em um primeiro momento, proporcionaram um aumento das 
áreas ulceradas, o que sugere uma ativação da fase inflamatória e conseqüente desbridamento das úlceras. Young e Dyson em 1989 já haviam observado aumento do crescimento capilar em úlceras induzidas experimentalmente em ratas que foram tratadas com ultra-som na freqüência de $0,75 \mathrm{MHz}$ e intensidade de $0,1 \mathrm{~W} / \mathrm{cm}^{2}$. O estudo utilizou um grupo placebo (irradiação simulada). O resultado sugere que ocorra a aceleração da proliferação inflamatória e uma cicatrização mais rápida das úlceras.

No final do tratamento, conforme tabela 4.3b, o grupo 2 apresentou um aumento médio da razão $r_{1}$ de cicatrização de $0,41 \mathrm{~cm}^{2}$, isto é, houve um aumento de $41 \%$ de reepitelização. No grupo 1 a média foi nula. Houve diferença estatística na razão $r_{1}$ de cicatrização entre os grupos, o que caracteriza uma ação benéfica do US na formação tecidual e remodelagem. Outros estudos também demonstraram diminuição da área da úlcera com a utilização do ultra-som (DYSON, et al., 1976; PESCHEN, et al., 1997; FRANEK, et. al., 2004).

O tecido de granulação é importante para a reepitelização e é caracterizado pela neovascularização. A fibrina é caracterizada pelas células mortas e é considerada um tecido maléfico para a cicatrização da úlcera. Analisando-se as tabelas $4.5 \mathrm{a}, 4.5 \mathrm{~b}, 4.6 \mathrm{a}$ e $4.6 \mathrm{~b}$ verificou-se que no grupo 1 ocorreu uma diminuição da granulação e um aumento da fibrina nos dias de tratamento em comparação ao $1^{\circ}$ dia. No grupo 2 observou-se um aumento da granulação e uma diminuição da fibrina em quase todos os dias de tratamento. Este fato não foi observado apenas no $15^{\circ}$ e $60^{\circ}$ dia. Em ambos os grupos, houve um aumento da fibrina no $75^{\circ}$ de tratamento, quando comparado ao $60^{\circ}$ dia, provavelmente relacionada ao aparecimento natural de fibrina no final da reepitelização, devido à lise do colágeno velho e a síntese do colágeno novo, que é caracterizada por uma fibrina mais 
esbranquiçada que a anterior (MITCHELLI, 2005). Verificou-se que no grupo 2 de acordo com as tabelas $4.3 \mathrm{~b}$ e $4.6 \mathrm{~b}$ simultaneamente ao aumento da fibrina, houve uma diminuição do diâmetro da úlcera, enquanto no grupo 1 , tabelas $4.3 a$ e $4.6^{a}$, não houve redução da úlcera, porém correu aumento de fibrina.

Observou-se diferença estatística entre os grupos experimentais na comparação da área de granulação no $30^{\circ}, 45^{\circ}, 60^{\circ}, 75^{\circ}$ e $90^{\circ}$ dias de tratamento, quando não incluídas as úlceras com área menor que $1,5 \mathrm{~cm}^{2}$. Quando as áreas menores que $1,5 \mathrm{~cm}^{2}$ foram incluídas na análise estatística houve diferença apenas no $75^{\circ}$ dia. A área de fibrina foi estatisticamente diferente no $30^{\circ}, 45^{\circ}, 75^{\circ}$ e $90^{\circ}$ dia com ou sem a inclusão das áreas menores que $1,5 \mathrm{~cm}^{2}$. No $60^{\circ}$ dia de tratamento houve diferença estatística somente quando as áreas menores que $1,5 \mathrm{~cm}^{2}$ foram incluídas. Observou-se que o US aumentou o tecido de granulação quando comparado ao tratamento com sulfadiazina $1 \%$, sugerindo com isso um aumento na neovascularização. Swist-Chmielewska et al. em 2002 observaram que não houve diferença estatística entre as úlceras tratadas com US $\left(1 \mathrm{w} / \mathrm{cm}^{2}\right.$ e $\left.0,5 \mathrm{w} / \mathrm{cm}^{2}\right)$ e as tratadas por métodos convencionais no desenvolvimento da granulação, durante 12 semanas (3meses) de tratamento. Os tratamentos foram administrados 3,2 e 1 vez por semana no $1^{\circ}, 2^{\circ}$ e $3^{\circ}$ mês de tratamento, respectivamente. As úlceras tratadas com US mostraram melhores resultados na diminuição da área e do volume das úlceras venosas resultando em uma cicatrização mais rápida.

Não houve diferença estatística na análise imunohistoquímica, mas pode-se observar na tabela 4.7 que as úlceras do grupo 2 em 45 dias tiveram um aumento $23 \%$ maior de iNOS do que no grupo 1 . Isto sugere uma possível estimulação da fase inflamatória pois esta enzima faz parte desta etapa da cicatrização. Este aumento da enzima iNOS nos primeiros 45 dias de tratamento pode justificar 0 
aumento da área superficial no $45^{\circ}$ dia de tratamento. Neste mesmo dia houve também um aumento dos fatores de crescimento TGF $\beta$ e VEGF em $44 \%$ e $31 \%$, respectivamente, em relação ao aumento dos mesmos fatores no grupo 1. Isto sugere que no grupo 2 ocorreu aumento de fibroblastos e de vasos sanguíneos, levando as úlceras a uma cicatrização mais rápida. Um estudo investigou o efeito do ultra-som (15 e 30 $\mathrm{mW} / \mathrm{cm}^{2}$ ) na produção de IL-8, FGF e VEGF in vitro em células de monócitos, fibroblastos e osteoblastos, concluindo que o VEGF alcançou o maior número de produção nos 3 tipos de células independentemente da intensidade (REHER et al.,1999). 
6. Conclusão 
O uso de uma película de látex (condon) no cabeçote de um transdutor ultrasônico não significou perda de energia transmitida podendo ser usada na estomatoterapia como uma forma de prevenção da transmissão de doenças infectocontagiosas.

Não houve diferença estatística significante nos resultados da análise de imagem de úlceras pelo software Image $^{\circledR}$ utilizando métodos padronizados e não padronizados de captura das mesmas.

O processamento das imagens de úlceras constitui uma ferramenta que deve ser implantada na rotina clínica de tratamento de úlceras para que os profissionais da área da saúde possam ter um registro quantitativo, visual e computadorizado da área da lesão, visando o aperfeiçoamento dos serviços de estomatoterapia.

O processamento das imagens de imunohistoquímica é uma técnica que deve ser implementada na análise da imunohistopatologia.

O US acelera todas as fases da cicatrização quando comparado ao tratamento com curativos diários à base de creme sulfadiazina de prata $1 \%$ (SDZ). $\mathrm{Na}$ fase inflamatória houve aumento da enzima iNOS proporcionando o desbridamento da ferida. Houve aumento dos fatores de crescimento TGF $\beta$ e VEGF que atuam na neovascularização e na remodelagem. No decorrer do tratamento o US mostrou ser mais eficiente no aumento da granulação e diminuição da fibrina, ocasionando uma reepitelização mais rápida das úlceras. 
7. Referências Bibliográficas 
ABBAS, A.K; LICHTMAN, A.H; POBER, J.S. (2003). Imunologia celular e molecular. 4.ed. Rio de Janeiro: Revinter.

ANASTÁCIO, M.A.D.J. (2000). Reparação epitelial em úlceras vasculares após estimulação do ultra-som pulsado de baixa intensidade. $89 p$. Dissertação (Mestrado em Bioengenharia) - Interunidades em Bioengenharia EESC/FMRP/IQSC, Universidade de São Paulo, São Carlos, 2000.

ARAI, T. et al. (1993). The effect of ultrasound stimulation on disuse osteoporosis. In: $13^{\text {th }}$ Annual Meeting of Bioelectrical Repair and Growth Society, Dana Point, CA, USA.

ARNOLD, F.; WEST, D. (1991). Angiogenesis in wound healing. Pharmacology and Therapeutic, New York, v.52, n.3, p.407-422, Dec.

AZUMA, Y. et al. (2001). Low-intensity pulsed ultrasound accelerates rat femoral fracture healing by acting on various cellular reactions involved in fracture repair. Journal of Bone and Mineral Research, New York, v.16, n.4, p.671-680.

BARROS, J.R. (2000). Insuficiência venosa crônica. In: PITTA, G.B.B.; CASTRO, A.A.; BURIHAN, E. Angiologia e cirurgia vascular: guia ilustrado. Maceio: UNISAL/ECMAL.

BENSON, P.E. et al. (2005). Measurement of White Lesions Surrounding Orthodontic Brackets: Captured Slides Vs Digital Camera Images. Angle Orthodontic, v.75, n.2, p. 226-300.

BERRIS, P.W. (2000) Acquisition of wound images and measurement of wound healing rate and status using color image processing. PhD Thesis - Department of Engineering, University of Reading Department of Engineering. September, 2000.

BIER, O. et al. (1982). Imunologia básica e aplicada. São Paulo: Guanabara.

BISHOP, J.B.; COLS (1992). A prospective randomized evaluator-blinded trial of two potential wound healing agents for the treatment of venous stasis ulcers. J. Vasc. Surg, v.16, p. 251-7.

BOECKX, W.; BLONDEEL, N.; VANDERSTEEN, K.; WOLF-PEETERS, C.; SCHMITZ, A. (1992). Effect of cerium nitrate-silver sulphadiazine on deep dermal burns: a histological hypothesis. Burns, v. 18, n. 6, p. 456-62.

BURGESS, A.W. (1989). Epidermal growth factor and transforming growth factor alfa. British Medical Bulletin, Australia, v.45, n.2, p.401-424.

CABRAL, A.L.S. (2000). Insuficiência venosa crônica de membros inferiores: prevalência, sintomas e marcadores preditivos. Tese (Doutorado em Medicina) Escola Paulista de Medicina, Universidade Federal de São Paulo, São Paulo, 2000.

CHETTIBI, S.; FERGUSON, M.W.J. (1999). Wound repair: an overview. In: GALLIN, j.i.; SNYDERMAN, R. Inflammation: basic principles and clinical 
correlates. $\quad 3^{\text {rd }}$ ed. Philadelphia: edited by John I. Gallin and Ralph Snyderman p.865-88.

CHOFFIE, M.; DUARTE, L.R. (1994). Low-intensity ultrasound and effects on ununited fractures. In: Read at the Orthopaedic Health Conference, June 15, São Paulo: University Hospital, Brazil.

CHILDRESS, B.B.; STECHMILLER, K.J. (2002). Role of nitric oxide in wound healing. Biological Research for Nursing, Canada, v.4, n.1, p.5-15, July.

COENRAADS, P.J., et al. (2005) Construction and validation of a photographic guide for assessing severity of chronic hand dermatitis. British Association of Dermatology, v.152, p. 296-301.

CORDTS, P.R. et al. (1992). A prospective, randomized, trial of unna's boot versus duoderm CGF hydroactive dressing plus compression in the management of venous leg ulcers. Journal of Vascular Surgery, St.Louis, v.15, n.3, p.80.

COOK, S. D; et. al. (2001). Improved Cartilage Repair after Treatment with LowIntensity Pulsed Ultrasound. Clinical Orthopaedics and Related Research, v.391, p. 231-243.

DAYTON, P.D.; PALLADINO, S.J. (1989). Electrical stimulation of cutaneous ulcerations. Journal of the American Podiatric Medical Association, v.79, n.7, p.318-321, july.

DUARTE, L.R. (1983). The stimulation of bone growth by ultrasound. Archives of Orthopedic and Traumatic Surgery, Munchem, v.101, n.3, p.153-159.

DUARTE, L.R.; XAVIER, C.A.; CHOFFIE, M. McCABE, J.M (1996). Review of nonunions treated by pulsed low-intensity ultrasound. Société Internationale de Chirurgie Orthopedique et de Traumatologie (SICOT), Amsterdam, p. 110.

Drug Information (2002), American Society of Health-System Pharmacist, 44th Edition, Bethesda - United States

DYSON, M. (1987). Mechanisms involved in therapeutic ultrasound. Physiotherapy, London, v.73, n.3, p.116-122.

DYSON, M. (1990). Role of ultrasound in Wound healing. In: KLOTH, L.C.; MC CULLOCH, J.M.; FREEDAR, J.A. Wound Healing. Philadelphia: FA Davis Co. p. 259-282.

DYSON, M.; SUCKLING, J. (1978). Stimulation of tissue repair by ultrasound: a survey of the mechanisms involved. Physiotherapy, London, v.64, n.4, p.105-108, Apr.

DYSON, M.; FRANKS, C.; SUCKLING, J. (1976). Stimulation of healing of varicose ulcers by ultrasound. Ultrasonics, London, v.14, n.5, p.232-236, Sept. 
FALANGA, V.; EAGLSTEIN, W.H. (1996). Úlceras dos membros inferiores: diagnóstico e tratamento. Rio de Janeiro: Revinter.

FISCHER, R. (1979). Progressos em cirurgias de varizes. São Paulo: Manole.

FOX, C.L.; MONAFO, W.W.; AYVAZIAN, et al. (1977). Topical chemotherapy for burns using cerium salts and silver sulfadiazine. Surg . Gynecol. Obstet., v. 144, p. 668.

FRADE, M.A.C. et al. (2001). Estudo clínico-epidemiológico de úlceras de perna em Juiz de Fora. In: Reunião Anual de Dermatologistas do Cone Sul. Anais da XXI RADLA, Foz do Iguaçu, p.84.

FRANEK, A. et al. (2004). Application of various power densities of ultrasound in the treatment of leg ulcers. Journal of Dermatology Treatment, v.15, n.6, p.379-386, Dec.

FRANKEL, V.H.; KOVAL, K.J.; KUMMER, F.J. (1999). Ultrasound treatment of tibial nonunions. American Academy of Orthopaedic Surgeons 66th Annual Meeting, Anaheim: p.4-8, Feb.

GEBAUER, D. et al. (2000). Nonunions treated by pulsed low-intensity ultrasound. Journal of Orthopedic Trauma, Hagerstown, v.14, n.2, p.154, Feb.

GLAZER, P.A. et al. (1998). Use of ultrasound in spinal arthodesis: a rabbit model. Spine, Philadelphia, v.23, n.10, p.1142-1148, May.

GOIHMAN-YAHR, M. (1997). Correspondence. International Journal of Dermatology, New York, v.36, p.399-400.

GUIRRO, E.; GUIRRO, R. (2002) Fisioterapia Dermato Funcional. 3. ed. São Paulo: Manoli. p. 13-22.

HAAR, G.T. (1978). Basic physics of therapeutic ultrasound. Physiotherapy, London, v.4, n.4, p.100-103, april.

HABIF, P.T. (2005). Guia colorido para diagnóstico e tratamento: dermatologia clínica. 4.ed. Porto Alegre: Artmed. p.15-36.

HADJIARGYROU, M. et al. (1998). Enhancement of fracture healing by lowintensity ultrasound. Clinical Orthopaedics and Related Research, Philadelphia, v.355S, p.216-229, Oct. Suppl.

HECKMAN, J. D.; RYABY, J.P.; MCCABE, J.; FREY, J.J.; KILCOYNE, R.F. (1994) Acceleration of Tibial Fracture Healing by Non-Invasive, Low-Intensity Pulsed Ultrasound, Journal of Bone and Joint Surgery, v.76,n.1, p.26-34.

HILÁRIO, M.L. (1993). Radiação ultra-sônica de baixa intensidade na reparação tecidual de úlceras tróficas de perna. 153p. Dissertação (Mestrado em Bioengenharia) - Programa Interunidades em Bioengenharia - ESC/FMRP/IQSC, Universidade de São Paulo, São Carlos, 1993. 
HINDRYCKX, P.H.; CUYPER, C.; HENDRICKX, B.; MULLIE, A. (1990) The treatment of infected decubitus ulcers with $1 \%$ silver sulfadiazine cream. Curr. Ther. Res., v.48, n.3, p. 535-9.

HOOGLAND, R. (1986). Terapia ultrasônica. Holanda: Enraf-Nonius. p.5-35.

HSU, S.; HUANG, T. (2004). Bioeffect of ultrasound on endothelial cells in vitro. Biomolecular Engineering, Amsterdam, v.2, n.3/5, p.99-104, Nov.

ITO, M. et al. (2000). Effects of ultrasound and 1,25 dihydroxyvitamin D3 on growth factor secretion in co-cultures of osteoblasts and endothelial cells. Ultrasound in Medicine \& Biology, Elmsford, v.26, n.1, p.161-166, Jan.

JUNQUEIRA, L.C.; CARNEIRO, J. (2004a). Sistema imunitário e órgãos linfáticos. In: Histologia básica. Rio de Janeiro: Guianabara Koogan.

Guianabara Koogan.

Histologia básica. Rio de Janeiro:

KANH, J. (1991). Ultrasound in principlels and paratice of electrotherapy. New York: Churchill Livingstone. Cap.4, p.51-70.

KARUKONDA, S.R. et al. (2000). The effects of drugs on wound healing: part 1. International Journal Dermatology, Philadelphia, v.39, n.4, p.250-257, Apr.

KINSLER, L.E.; FREY, A.R.; COPPENS, A.B; SANDERS, J.V. (1982) In: Tranmission Phenomena. Fundamentals of Acoustics, John Wiley \& Sons.

KIRSNER, R.S.; EAGLSTEIN, W.H. (1993). The wound healing process. Dermatology Clinics. Florida, v.11, n.4, p.629-640, Oct.

KOKUBO, T. et al. (1999). Low-intensity pulsed ultrasound exposure increases prostaglandin E2 production via the induction of cyclooxygenase-2 mRNA in mouse osteoblasts. Biochemical and Biophysical Research Communications, New York, v.256, n.2, p.285-287, Mar.

KREMKAU, F.W. (1985). Phisical considerations. In: NYBORG, L.N.; ZISKIN, M.C. Biological effects of ultrasound. New York: Churchill Livingstone. Cap.2, p.9-21.

KRISTIANSEN, T.K.; RYABY, J.P.; MCCABE J.; FREY, J.J.; ROE, L.R. (1997) Accelerated healing of distal radial fractures with the use of specific, low-intensity ultrasound. Journal of Bone and Joint Surgery, v.79, n.7, p.961-973.

KUCAN, J.O.; ROBSON, M.C.; HEGGERS, J.P.; KO, F. (1981). Comparison of siver sulfadiazine, povidone-iodine and physiologic saline in the treatment of cronic pressure ulcers. J. Am. Ger. Soc, v.29, n.5, p. 232-5. 
LEHMANN, J.F.; GUY, A.W. (1972). Ultrasound therapy. In: REID, J.; KIKOV, M. Interaction, of ultrasound and biological tissues. Washington: USA Government Printing Office. (Dhew Publication, (FDA) n 73-8008). p.141-152.

LUNDENBERG, T. et al. (1990). Pulsed ultrasound does not improve healing of venous ulcer. Scandinavian Journal of Rehabilitation Medicine, Stockholm, v.22T, n.4, p.195-197.

MAFFEI, F.H.A. (2002). Varizes dos membros inferiores, epidemiologia, etiopatogenia e fisiopatologia. In:

3.ed. Rio de Janeiro: MEDSI. p.1499-1510.

Doenças vasculares periféricas.

MAYR, E.; WAGNER, S.; RÜTER, A. (1997). Treatment of nonunions by means of low intensity ultrasound. Der Unfallchirurg, Berlim, v.268, p.958-962.

MEANI, E.; ROMANO, C.L. (1997). Low-intensity pulsed ultrasound for the treatment of septic nonunion. In: Third Congress of the European Federation of National Associations of Orthopaedics and Traumatology, Barcelona.

MEDEIROS, G.C.F. (2001) Uso de texturas para o acompanhamento da evolução do tratamento de úlceras dermatológicas. Dissertação de Mestrado Escola de Engenharia, Universidade de São Paulo, São Carlos, 2001.

MELETTE, H. C.; HUTT, B. K.; ASKOVITZ, S.I.; HOVARTH, S. M. (1955). Diurnal Variations in body temperatures. J. Appl. Phisiol. $3^{\text {a }}$ ed. p. 665-675.

MITCHELLI, N.R. (2005). Tecido de renovação e reparação: regeneração, cicatrização e fibrose. In: KUMAR, V.; ABBAS, A.K.; FAUSTO, N. Robbins \& Cotran Patologia: bases patológicas das doenças. 7.ed. Rio de Janeiro: Interamericana. v.29, p. 91-124.

OKUNO, E.; CALDAS, I.L.; CHOW, C. (1986). Física para ciências biológicas e biomédicas. São Paulo: Harba.

ORMISTON, M.C. et al. (1985). Contolled trial of iodosorbin chronic venous ulcers. British Medical Journal, London, v.291, n.6491, p.308-310, Aug.

PESCHEN, M. et al. (1997). Low-frequency ultrasound treatment of chronic venous leg ulcers in an outpatient therapy. Acta Dermato-Venereologica, Germany, v.77, n.4, p.311-314, July.

PHILLIPS, T.J.; DOVER, J.S. (1991). Leg ulcers. Journal of the American Academy Dermatology, St.Louis, v.25, n.6, p.965-987, Dec.

PICCINATO, C.E.; COUTINHO-NETTO, J.; CHERRI, J. (2003). Cicatrização. In: CAMPOS, C.A.H.; COSTA, H.O.O. (Ed.). Tratado do otorrinolaringologia. São Paulo: Roca. Cap.12, p.189-200.

PITTA, G.B.B.; CASTRO, A.A.; BURIHAN, E. (2000). Angiologia e cirurgia vascular: guia ilustrado. Maceió: UNISAL/ECMAL. 
PILLA, A.A., MONT, M.A., NASSER P.R., KHAN A.S., FIGUEIREDO M., KAUFMAN J.J, SIFFERT R.S (1990). Non-Invasive Low-Intensity Pulsed Ultrasound Accelerates Bone Healing in the Rabbit, Journal of Orthopaedic Trauma, v.4,n.3, p.246-253.

RAWOOL, D. et al. (2003). Power Doppler assessment of vascular changes during fracture treatment with low-intensity ultrasound. Journal of ultrasound in medicine, Pennsylvania, v.22, n.2, p.145-53, Feb.

RATNER, D. (2000). Real photographic prints from digital images. Dermatology surgery, v. 26, p. 799-800.

REHER, P. et al. (1999). Effect of ultrasound on the production of IL-8, basic FGF and VEGF. Cytokine, Amsterdam, v.1, n.6, p.416-423, June.

RIVITTI, S. (2001). Dermatologia. 2.ed. São Paulo: Artes Médicas.

ROMANO, C.; MESSINA, J.; MEANI, E. (1999). Low-intensity ultrasound for the treatment of infected nonunions. In: AGAZZI, M. et al. Guarderni di infezione osteoarticolari. Milan: Masson Periodical Division. p.83-93.

ROSS, M. H.; REITH, E. J. ( 1993) Histologia Texto e Atlas. 2.ed. São Paulo: Médica Pam Americana. p. 354

RUBIN, C. et al. (2000). The use of low-intensity ultrasound to accelerate the healing of fractures. Journal of Bone and Joint Surgery, Boston, v.83-A, n.2, p.259-270, Feb.

RUBIN, J.R. et al. (1990). Unnas boot poyuretane foan dressings for the tratmente of venous ulcerations: a randomized propesctive study. Archives of Sugery, Chicago, v.125, n.4, p.489-490, Apr.

RYABY, J.T.; DUARTE-ALVES, P.; PILLA, A.A. (1989). Clinically effective ultrasound affects second messenger activity in bone cell cultures. Trans. BRAGS, v.9, p.42.

. (1990). Ultrasound and static mechanical force affect second messenger activity in bone cell cultures. Trans. Orthop. Res. Soc., v.15, p.131.

RYABY, J.T.; MATTHEW, J.; DUARTE-ALVES, P. (1992). Low-intensity pulsed ultrasound affects adenylate cyclase and TGF-ß synthesis in osteoblastic cells. Trans. Orthop. Res. Soc., v.17, p.590.

RYABY, J.T. et al. (1991). Low-intensity pulsed ultrasound modulates adenylate cyclase activity and transforming growth factor beta synthesis. In: BRIGHTON, C.T.; POLLOCK, S.R. Electromagnetics in biology and medicine. San Francisco: San Francisco Press. p.95-100. 
SANTANA, L. A. (2003). O uso do ultra-som de baixa intensidade em Úlcera de pele. Monografia (Graduação em Fisioterapia) - Universidade de Cruz Alta, Cruz Alta, 2003.

SATO, W.; TAJASHI, M.; NAKAMURA, K. (1999). Acceleration of increase in bone mineral content by low-intensity ultrasound energy in leg lengthening. Journal of Ultrasound in Medicine, Philadelphia, v.18, n.10, p.699-702, Oct.

SHAI, A; MAIBACH, H.I. (2005). Wound healing and ulcers of the skin. Germany: Springer-Verlag Berlin Heidelberg. p. 91-92.

SHIRATORI, C.A. et al. (2005). Avaliações das dimensões orbitárias de coelhos após enucleação e evisceração. Arquivo Brasileiro de Oftalmologia, v. 68, n.2, p. 235-239.

STRAUSS, E.; OPPENHEIM, W.; PETRUCELLI, R.C. (1996). Accelerated fracture healing with pulsed low-intensity ultrasound. Société Internationale de Chirurgie Orthopedique et de Traumatologie (SICOT), P2.111: PDS30.

SOARES, S.C. et al. (2004). Úlcera de perna tratamento e cicatrização. HU Revista, Juiz de Fora, v.30, n.2/3, maio.

SWIST-CHMIELEWSKA, D. et al. (2002). Experimental selection of best physical and application parameters of ultrasound in the treatment of venous crural ulceration. Polski Merkuriusz Lekarski, Katowicach, v.12, n.72, p.500-505, June.

TANG, C., et. al. (2006). Ultrasound Stimulates Cyclooxygenase-2 Expression and Increases Bone Formation through Integrin, Focal Adhesion Kinase, Phosphatidylinositol 3-Kinase, and Akt Pathway in Osteoblasts. Molecular Pharmacology, v. 69, n. 6, p. 2046-2056.

TANZER, M. et al. (1995). The effect of non-invasive low intensity ultrasound on bone growth into porous coated implants. In: Annual Meeting, Orlando: Orthopaedic Research Society, v.41

VICENTE, M.F.R. et al. (2000). Efeitos da estimulação ultra-sônica de baixa intensidade em osteotomias de mandíbula - estudo experimental em coelhos. 193p. Dissertação (Mestrado em Bioengenharia) - Interunidades em Bioengenharia - EESC/FMRP/IQSC, Universidade de São Paulo, São Carlos, 2000.

VIDAL, B.C.; MELLO, M.L.S. (1987). Biologia celular. Rio de Janeiro: Atheneu.

XAVIER, C.A.M.; DUARTE, L.R. (1983). Ultrasonic stimulation of bone callus: clinical application. Rev. Brazil Orthop, v.18, p.73-80.

ZORN, T.M.T. (2004). Tecido conjuntivo. In: JUNQUEIRA, L.C.; CARNEIRO, J. Histologia básica. Rio de Janeiro: Guianabara-Koogan. p. 92-124.

YANG, R. et. al. (2005). Regulation by ultrasound treatment on the integrin expression and differentiation of osteoblasts. Bone v. 36, p. 276-283. 
YOUNG, S.R.; DYSON, M. (1990). Macrophage responsiveness to therapeutic ultrasound. Ultrasound in Medicine \& Biology, Elmsford, v.16, n.8, p.809-816, Apr.

YOUNG, S.R.; DYSON, M. (1989). The effect of therapeutic ultrasound on angiogenesis. Ultrasound in Medicine \& Biology, Elmsford, v.16, n.3, p.261-269, Oct.

WANG, S.J. et al. (1994) Low-intensity ultrasound treatment increases strength in a rat femoral fracture model. Journal of Orthopaedic Research, New York, v.12, n.1, p.40-47, Jan.

WARD, R.S.; SAFLLE J.R. (1995) Topical agents in burn and wound care. Phys Ther, v.75, n.6, p.526-38.

WARDEN, S.J. (2000). Acceleration of fresh fracture repair using the sonic accelerated fracture healing system: a review. Calcified Tissue International, New York, v.66, n.2, p.157-163, Feb.

WEICHENTHAL, M. et al. (1997). Low-frequency ultrasound treatment of chronic venous ulcers. Wound Repair and Regeneration, v.5, n.5, p.18-22, Jan.

WIENER, W. et.al. (1991). Leg ulcers due venous insufficiency. In: WESTERHOF, W. (Ed.). Leg ulcers diagnosis and tratment. Amsterdam: Elsevier. Cap.7.

WILLIANS, R. (1987) Production and Transmission of Ultrasound. Vol.73, $\mathrm{n}^{\circ} 3$.

WITTE, M.B.; BARBUL, A. (1997). General principles of wound healing. Surgical Clinics of North America, Oxford, v.77, n.3, p.509-528. 
8. Anexos 


\section{Anexo A}

\section{Termo de Consentimento}

(Este termo deverá ser lido, entendido, preenchido e assinado pelo paciente ou pelo familiar responsável quando se tratar de pacientes inconscientes)

Resumo simplificado do Trabalho: "Avaliação imunohistopatológica do tratamento de úlceras perna por ultra-som de baixa intensidade"

Introdução: $\mathrm{O}$ uso de ultra-som para o tratamento das feridas de perna estimula a cicatrização, podendo fechar mais rapidamente as feridas.

Objetivo: Avaliar o uso do ultra-som no tratamento das feridas de perna buscando conhecer as modificações que ocorrem com os tecidos da ferida durante o tratamento.

Justificativa: $O$ trabalho se justifica na busca de padronizar a utilização do ultrasom de baixa intensidade no tratamento das feridas de perna, isolado ou associado a outras formas de tratamento/curativos como a biomembrana de látex natural.

Procedimento: $O$ paciente voluntário deverá ler o termo de consentimento abaixo, responder a um protocolo (anexo), além de permitir um exame dermatológico geral. Deverá concordar com a realização das biópsias para avaliar as características dos tecidos das feridas, do tratamento com ultra-som que será aplicado em torno da ferida por aproximadamete 20 minutos, através de um transdutor de ultra-som, sem perfuração ou penetração da pele, além dos curativos com biomembrana de látex que deverão se trocados 3 vezes por semana, após lavagem da ferida com soro fisiológico e cobertura com gazes e crepom.

$\mathrm{Eu}$ Identidade ou certidão de nascimento $n^{\circ}$ Residente à $\mathrm{n}^{\circ}$

DN Sexo: $\overline{(\mathrm{M})} \overline{\mathrm{M}} \overline{\mathrm{F}}$

Estado Bairro

Cidade:

Declaro que recebi por escrito, li e compreendi o resumo do trabalho de pesquisa "Avaliação imunohistopatológica do tratamento de úlceras perna por ultra-som de baixa intensidade" HC -FMRP - USP e estou disposto a participar voluntariamente neste trabalho como paciente com lesão ulcerada, por saber que não me causará nenhum mal ou risco.

- Terei a liberdade de a qualquer momento discordar, não colaborar ou desistir de participar desta pesquisa. Apenas ofereço-me para os seguintes estudos:

- Preencher uma ficha que me identifica e permitir que me examine a pele em busca de lesões cutâneas. Isto será feito sobre orientação de um dos participantes, sem risco para minha pele ou qualquer parte do meu corpo;

- Aceitarei que os pesquisadores fotografem minha ferida e sua evolução.

- Aceitarei que os pesquisadores coletem amostra de meu sangue (15ml), semelhante ao exame de sangue normal (se necessário), alem da realização de biópsias em minha pele e do conhecimento dos resultados desses exames;

- Estas informações que darei serão sigilosas (guardadas em segredo) sendo que não terei meu nome citado em momento algum tendo minha imagem protegida sempre;

- Não permitirei nenhum tipo de atitude que não queira, os exames serão feitos de forma que eu concordar, respeitando-me inteiramente; 
- Serão respeitadas quaisquer vontades minhas como religião, cultura e valores pessoais que não me façam aceitar qualquer um desses exames ou questionário;

- Sei também que desta forma ajudarei no estudo científico do tratamento das úlceras.

- Para qualquer esclarecimento, acompanhamento ou tratamento dermatológico, terei acesso aos serviços dos médicos desta pesquisa, que me forneceram seu endereço e contatos caso eu queira.

Ribeirão Preto, de de

Assinatura do Paciente

Examinador 


\section{Anexo B}

\section{Avaliação imunohistopatológica do tratamento de úlceras de perna por ultra-som de baixa intensidade (ADUN-HCFMRP-USP)}

Indentificação:

Nome:

Residência.

Profissão.

\section{Exame Geral:}

Doença de Base: ( ) Arteriosclerose ( )Insuf. Arterial ( ) Insuf . Venosa ( ) Diabetes tipol ( ) Diabetes tipo II ( )AVC ( )TVE ( )HAS ( )Epilepsia ( )Alcoolismo ( ) Outras doenças associadas:

Medicamentos em uso: ( )ATB ( )Anti hipertensivo ( )Hipoglicemiantes ( ) Vitaminas ( ) Insulina

( ) Anticoagulante ( ) Quimioterápicos ( ) Imunossupresor ( ) Hemotransfusões ( )

Outros

\section{Exames Laboratoriais:}

Hemoglobina. . $\mathrm{g} \%$ Glicemia. .$g \%$ Albubina g/dl

Exame Físico:

\section{Exame da Ferida:}

Comprometimento Tecidual: ( )Estágio I （）Estágio II （ )Estágio III （ )Estágio IV Maior Extensão: Vertical. ..cm Horizontal. .cm

Presença de Tecido Necrótico: ( ) Não ( ) Sim Exsudato:( ) Não ( ) Sim Característica: ( ) Serosa ( ) Sero Sanguinolenta ( )Sanguinolenta ( ) Purolento

Volume: ( ) Ausente ( ) Pouco (1 pct. gaze) ( ) Moderado (3 pct. gazes)

$$
\text { ( )Acentuado ( mais de } 3 \text { pct. gazes) }
$$

Sinais de Infecção:( ) Não ( ) Sim Quais

Odor: ( ) Ausente ( )Discreto ( ) Acentuado

Dor/Escore: ( ) Ausente ( )leve ( ) Moderada ( ) Intensa

Tempo de Existência:............. Já cicatrizou anteriormente? ( )Sim ( ) Não

\section{Exame Histopatológico:}

\section{Inicial:}

Exame Fotográfico:

\begin{tabular}{|l|l|l|l|l|l|l|}
\hline Inicial: & 15d: & 30d: & 45d: & 60d: & 75d: & $90 \mathrm{~d}:$ \\
\hline
\end{tabular}

\section{Avaliação Terapêutica:}

\begin{tabular}{|l|l|l|l|}
\hline \multicolumn{1}{|c|}{ Resposta ao tto } & \multicolumn{2}{c|}{ Ferida } \\
\hline Aspecto clínico observado & Sim & Não & Data \\
\hline Evidência de granulação & & & \\
\hline Evidência de reepitelização & & & \\
\hline Reepitelização total & & & \\
\hline Aumento da úlcera & & & \\
\hline Controle da Cor & & & \\
\hline Suspensão do tto & & & \\
\hline Abandono do tto & & & \\
\hline
\end{tabular}

Causas da Suspensão:

Causas do Abandono: 


\section{Anexo C \\ Detalhamento da realização do procedimento imunohistoquímico}

Etapa 1 - As peças biopsiadas foram colocadas em soro fisiológico 0,9\%, em seguida acondicionadas em "Tissue Tek ${ }^{\circledR n}$ e congeladas à temperatura de $-70^{\circ} \mathrm{C}$.

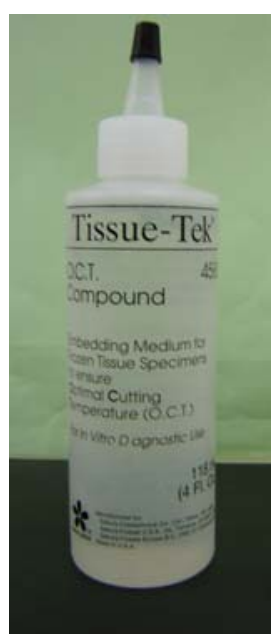

Figura 8.1 - Tissue Tek

Etapa 2 - As mostram foram levadas ao criostato na temperatura de $-21^{\circ} \mathrm{C}$ para realização dos cortes medindo $10 \mu \mathrm{m}$ de espessura.
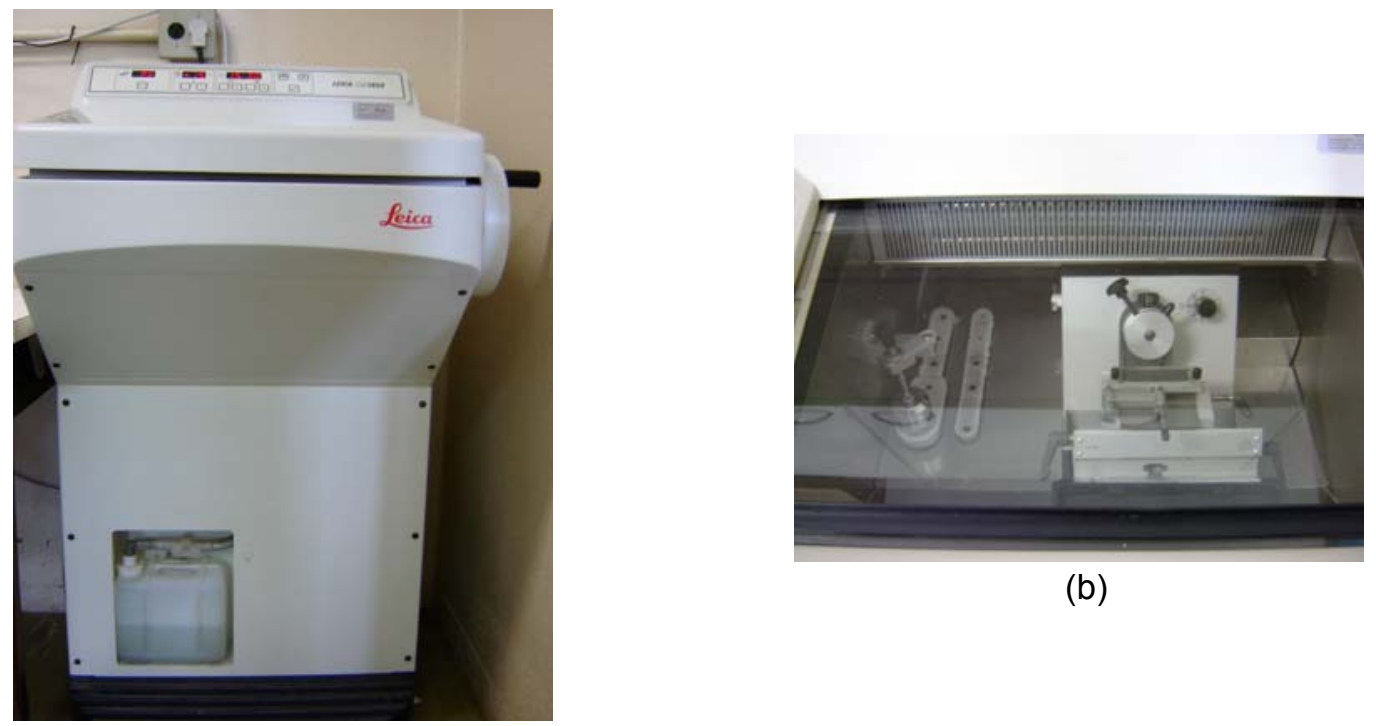

(b)

(a)

Figura 8.2 - (a) Frente do criostato; (b) Interior do criostato

Etapa 3 - Os cortes foram realizados em duplicatas e distribuídos paralelamente nas lâminas de microscopia. 


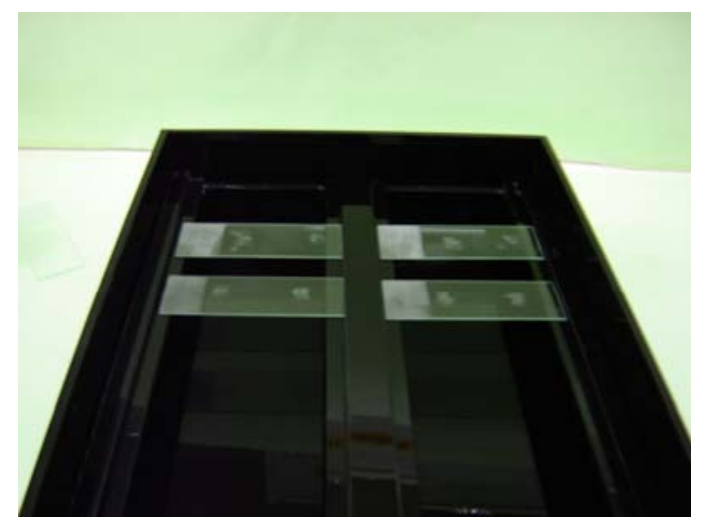

Figura 8.3 - Cortes das peças biopsiadas

Etapa 4 - As lâminas foram colocadas na acetona por 5 minutos no freezer à $-20^{\circ} \mathrm{C}$

Etapa 5 - As lâminas foram submetidas ao descongelamento em temperatura ambiente por 5 minutos, lavagens em solução salina tamponada com fosfato (PBS) $0,01 \mathrm{M}$ por 3 vezes de 5 minutos.

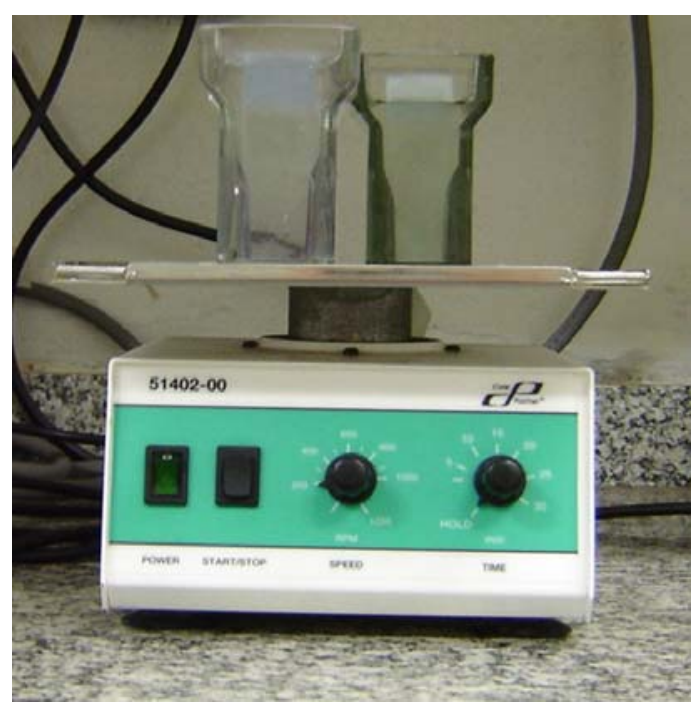

Figura 8.4 - Lâminas em PBS no agitador orbital

Etapa 6 - Para o bloqueio da peroxidase endógena os cortes foram submetidos ao peróxido de hidrogênio por 40 minutos $\left(\mathrm{H}_{2} \mathrm{O}_{2} 30\right.$ vol.) a $3 \%$, diluído em PBS $0,01 \mathrm{M}$, sempre pipetando $50 \mu \mathrm{l}$ em cada corte. 


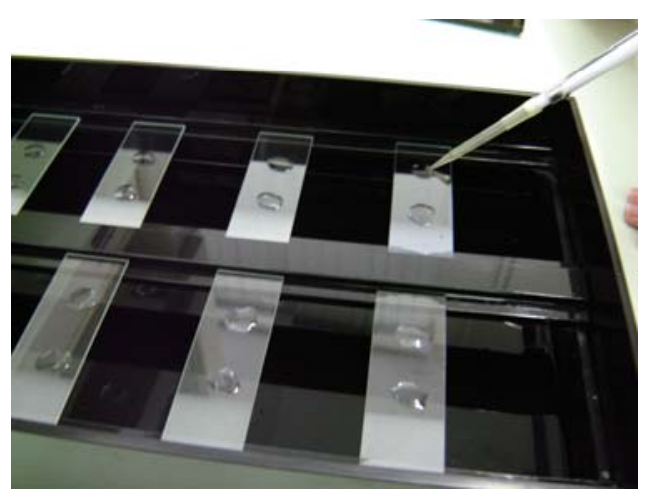

Figura 8.5 - Cortes sendo pipetados

Etapa 7 - As lâminas foram lavadas em PBS $0,01 \mathrm{M}$ por 3 vezes de 5 minutos sob agitação orbital (figura 8.4).

Etapa 8 - As ligações protéicas inespecíficas foram bloqueadas com albumina de soro bovino (BSA) diluído em PBS 0,01M por 40 minutos de incubação (figura 8.5).

Etapa 9 - As lâminas foram escorridas e acrescentados os anticorpos primários específicos diluídos em solução de PBS e albumina sérica bovina a 1\% (PBSA 1\%) na concentração de 1:100 para VEGF (A-20) rabbit IgG anti-human sc-152 (Santa Cruz Biotechnology), 1:200 para iNOS (N-20) rabbit IgG anti-human sc-651 (Santa Cruz Biotechnology) e 1:300 para TGF- $\beta_{1}$ (V) rabbit IgG anti-human sc-146 (Santa Cruz Biotechnology). Cinqüenta microlitros de anticorpo foram pipetados sobre 0 fragmento fixado na lâmina (Figura 8.5). As lâminas foram colocadas em câmara úmida e incubadas overnight à $4^{\circ} \mathrm{C}$.

Etapa 10 - As lâminas foram lavadas com PBS $0,01 \mathrm{M}$ por 3 vezes de 5 minutos sob agitação orbital (figura 8.4).

Etapa 11 - Os cortes foram incubados por 30 minutos com o anticorpo secundário biotinilado anti-rabbit IgG $(H+L)$ made in goat BA-1000 VECTOR (1:200) diluídos em PBSA 1\% (figura 8.5).

Etapa 12 - As lâminas foram lavadas em PBS $0,01 \mathrm{M}$ por 3 vezes de 5 minutos sob agitação orbital (figura 8.4). 
Etapa 13 - Os cortes foram incubados com HRP-Streptavidina (Santa Cruz Biotechnology) por 30 minutos à temperatura ambiente, protegido da luz (figura 8.5).

Etapa 14 - As lâminas foram lavadas em PBS 0,01M por 3 vezes de 5 minutos sob (figura 8.4).

Etapa 15 - Para revelação da ação da peroxidase, os cortes foram incubadas pela

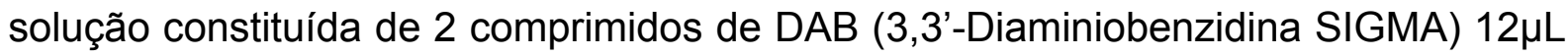
de $\mathrm{H}_{2} \mathrm{O}_{2} 30 \%$ e $15 \mathrm{~mL}$ de PBS $0,01 \mathrm{M}$, pipetados $50 \mu \mathrm{l}$ em cada corte (figura 8.5), mantendo pelo período máximo de 1 minuto, controlando a intensidade da cor. Em seguir, a reação foi interrompida, lavando-se as mesmas com água destilada.

Etapa 16 - A contra-coloração foi feita com Hematoxilina de Harris. As lâminas foram colocadas na solução por 20 segundos (figura 8.6) e posteriormente lavadas com água corrente e água destilada.

Etapa 17 - As lâminas foram desidratadas através da bateria de alcóois e xilóis (figura 8.7).

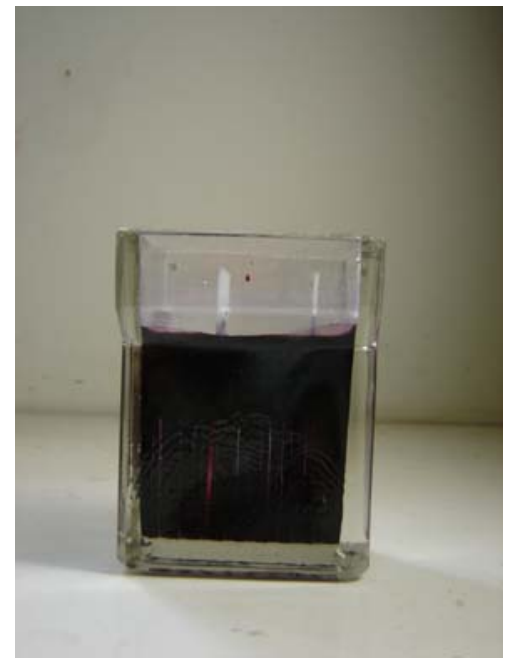

Figura 8.6 - Hematoxilina de Harris

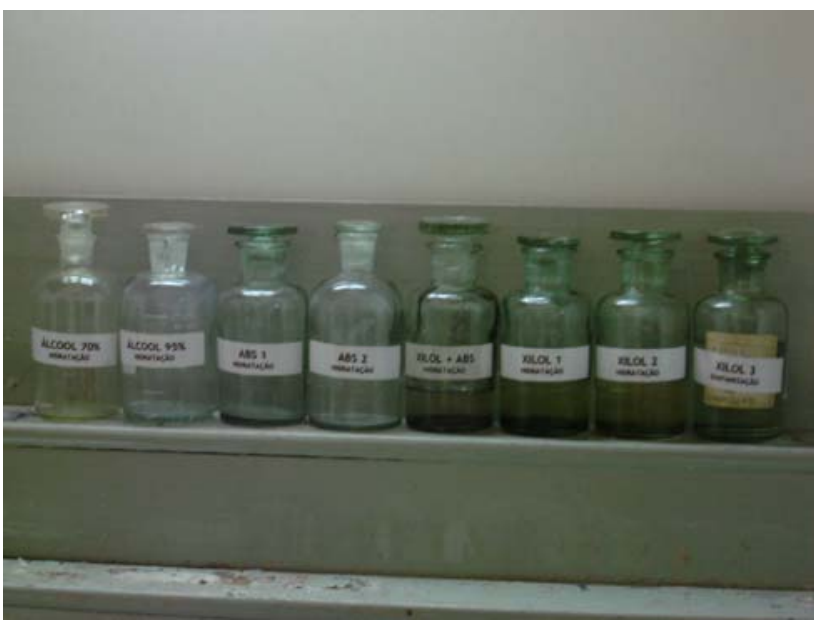

Figura 8.7 - Bateria de álcoois e xilóis

Etapa 18 - Montagem com Entellan ${ }^{\circledR}$ da lâmínula na lâmina. 


\section{Anexo D}

Evolução das áreas das úlceras de perna do grupo 1 (SDZ) e do grupo 2 (US) e dos respectivos tecidos de granulação e fibrina

Tabela 8.1a - Evolução das áreas das úlceras de perna do grupo 1(SDZ)

\begin{tabular}{|c|c|c|c|c|c|c|c|}
\hline \multirow[t]{2}{*}{ Dia } & \multicolumn{7}{|c|}{ Áreas $\left(\mathrm{cm}^{2}\right)$} \\
\hline & $1^{\circ}$ & $15^{\circ}$ & $30^{\circ}$ & $45^{\circ}$ & $60^{\circ}$ & $75^{\circ}$ & $90^{\circ}$ \\
\hline 1 & 13,82 & 13,83 & 25,92 & 27,32 & 19,87 & 20,73 & 21,35 \\
\hline 2 & 7,14 & 6,79 & 10,81 & 8,29 & 7,45 & 8,72 & 8,18 \\
\hline 3 & 102,54 & 104,64 & 122,23 & 136,73 & 106,36 & 100,45 & 125,30 \\
\hline 4 & 43,70 & 44,05 & 42,59 & 42,87 & 33,58 & 36,44 & 49,02 \\
\hline 5 & 7,54 & 7,38 & 7,27 & 6,27 & 9,34 & 9,19 & 8,66 \\
\hline 6 & 0,97 & 0,87 & 0,00 & 0,00 & 0,00 & 0,00 & 0,00 \\
\hline 7 & 21,92 & 20,36 & 22,56 & 21,85 & 22,03 & 22,43 & 22,36 \\
\hline
\end{tabular}

Tabela 8.1b - Evolução das áreas das úlceras de perna do grupo 2 (US)

\begin{tabular}{|c|c|c|c|c|c|c|c|c|}
\hline \multirow[t]{2}{*}{ Dia } & \multicolumn{8}{|c|}{ Áreas $\left(\mathrm{cm}^{2}\right)$} \\
\hline & $1^{\circ}$ & $15^{\circ}$ & $30^{\circ}$ & $45^{\circ}$ & $60^{\circ}$ & $75^{\circ}$ & $90^{\circ}$ & $105^{\circ}$ \\
\hline 1 & 0,32 & 0,45 & 0,32 & 0,11 & 0,00 & 0,00 & 0,00 & - \\
\hline 2 & 9,93 & 13,44 & 14,61 & 15,42 & 10,58 & 7,46 & 3,23 & 0,00 \\
\hline 3 & 2,36 & 2,04 & 2,53 & 2,21 & 1,82 & 1,72 & 1,73 & - \\
\hline 4 & 31,90 & 38,01 & 34,64 & 30,62 & 29,53 & 26,73 & 32,01 & - \\
\hline 5 & 16,72 & 23,44 & 25,23 & 25,72 & 22,70 & 27,51 & 20,22 & - \\
\hline 6 & 1,15 & 1,22 & 0,81 & 0,60 & 0,00 & 0,00 & 0,00 & - \\
\hline 7 & 7,82 & 6,36 & 8,22 & 9,31 & 8,63 & 8,04 & 6,82 & - \\
\hline 8 & 17,82 & 14,33 & 11,10 & 12,12 & 12,04 & 11,89 & 11,04 & - \\
\hline 9 & 71,77 & 74,13 & 72,01 & 52,56 & 66,51 & 43,78 & 40,82 & - \\
\hline
\end{tabular}


Tabela 8.2a - Evolução das áreas do tecido de granulação do grupo 1 (SDZ)

\begin{tabular}{|c|c|c|c|c|c|c|c|}
\hline \multirow[t]{2}{*}{ Dia } & \multicolumn{7}{|c|}{ Áreas $\left(\mathrm{cm}^{2}\right)$} \\
\hline & $1^{\circ}$ & $15^{\circ}$ & $30^{\circ}$ & $45^{\circ}$ & $60^{\circ}$ & $75^{\circ}$ & $90^{\circ}$ \\
\hline 1 & 5,93 & 7,11 & 6,72 & 14,76 & 10,62 & 14,63 & 12,15 \\
\hline 2 & 4,76 & 5,01 & 4,32 & 5,73 & 5,14 & 4,00 & 4,50 \\
\hline 3 & 56,82 & 50,39 & 64,62 & 67,94 & 59,58 & 59,61 & 83,72 \\
\hline 4 & 38,84 & 35,82 & 10,08 & 21,25 & 25,21 & 14,66 & 18,94 \\
\hline 5 & 5,67 & 2,34 & 3,02 & 3,41 & 5,07 & 6,10 & 6,22 \\
\hline 6 & 0,91 & 0,75 & 0,00 & - & - & - & - \\
\hline 7 & 14,58 & 16,02 & 16,13 & 12,59 & 16,06 & 16,24 & 17,81 \\
\hline
\end{tabular}

Tabela 8.2b - Evolução das áreas do tecido de granulação do grupo 2 (US)

\begin{tabular}{|c|c|c|c|c|c|c|c|c|}
\hline \multirow{2}{*}{ Uia } & \multicolumn{7}{c|}{ Áreas $\left(\mathbf{c m}^{2}\right)$} \\
\cline { 2 - 9 } & $1^{\circ}$ & $15^{\circ}$ & $\mathbf{3 0}$ & $\mathbf{4 5 ^ { \circ }}$ & $\mathbf{6 0}$ & $\mathbf{7 5}^{\circ}$ & $\mathbf{9 0 ^ { \circ }}$ & $\mathbf{1 0 5}^{\circ}$ \\
\hline 1 & 0,27 & 0,35 & 0,29 & 0,11 & 0,00 & - & - & - \\
\hline 2 & 7,96 & 10,78 & 11,87 & 12,55 & 9,96 & 6,24 & 2,82 & 0,00 \\
\hline 3 & 1,23 & 1,34 & 2,26 & 2,21 & 1,82 & 1,72 & 1,73 & - \\
\hline 4 & 18,93 & 23,46 & 25,69 & 21,77 & 20,18 & 20,68 & 23,36 & - \\
\hline 5 & 5,73 & 11,12 & 12,54 & 22,11 & 14,69 & 19,98 & 13,47 & - \\
\hline 6 & 0,97 & 0,65 & 0,53 & 0,42 & 0,00 & - & - & - \\
\hline 7 & 6,24 & 5,29 & 6,68 & 8,37 & 7,65 & 6,78 & 6,82 & - \\
\hline 8 & 14,73 & 8,47 & 7,62 & 8,07 & 7,39 & 9,25 & 9,74 & - \\
\hline 9 & 60,33 & 58,68 & 65,74 & 52,56 & 56,58 & 43,78 & 40,82 & - \\
\hline
\end{tabular}


Tabela 8.3a - Evolução das áreas do tecido de fibrina do grupo 1 (SDZ)

\begin{tabular}{|c|c|c|c|c|c|c|c|}
\hline \multirow[t]{2}{*}{ Dia } & \multicolumn{7}{|c|}{ Áreas $\left(\mathrm{cm}^{2}\right)$} \\
\hline & $1^{\circ}$ & $15^{\circ}$ & $30^{\circ}$ & $45^{\circ}$ & $60^{\circ}$ & $75^{\circ}$ & $90^{\circ}$ \\
\hline 1 & 7,53 & 6,79 & 19,14 & 12,64 & 8,87 & 6,13 & 9,25 \\
\hline 2 & 2,24 & 1,79 & 6,43 & 2,57 & 2,36 & 4,72 & 3,66 \\
\hline 3 & 45,01 & 52,21 & 57,68 & 68,86 & 46,82 & 40,54 & 37,68 \\
\hline 4 & 4,90 & 5,36 & 32,52 & 21,65 & 8,34 & 21,34 & 30,16 \\
\hline 5 & 1,92 & 5,06 & 4,25 & 2,88 & 4,33 & 3,06 & 2,45 \\
\hline 6 & 0,00 & 0,12 & 0,00 & - & - & - & - \\
\hline 7 & 7,42 & 4,37 & 6,27 & 9,21 & 5,74 & 5,26 & 4,17 \\
\hline
\end{tabular}

Tabela 8.3b - Evolução das áreas do tecido de fibrina do grupo 2 (US)

\begin{tabular}{|c|c|c|c|c|c|c|c|c|}
\hline \multirow{2}{*}{ Uia } & \multicolumn{7}{|c|}{ Áreas $\left(\mathbf{c m}^{2}\right)$} \\
\cline { 2 - 9 } & $1^{\circ}$ & $15^{\circ}$ & $\mathbf{3 0}$ & $\mathbf{4 5}$ & $\mathbf{6 0}$ & $\mathbf{7 5}^{\circ}$ & $\mathbf{9 0 ^ { \circ }}$ & $\mathbf{1 0 5}^{\circ}$ \\
\hline 1 & 0,13 & 0,00 & 0,11 & 0,00 & 0,00 & - & - & - \\
\hline 2 & 2,04 & 1,71 & 1,92 & 0,85 & 0,34 & 1,12 & 0,26 & 0,00 \\
\hline 3 & 0,95 & 0,76 & 0,32 & 0,00 & 0,00 & 0,00 & 0,00 & - \\
\hline 4 & 10,10 & 14,62 & 9,01 & 8,93 & 6,42 & 6,12 & 8,14 & - \\
\hline 5 & 10,65 & 12,31 & 12,72 & 3,67 & 6,81 & 7,22 & 6,83 & - \\
\hline 6 & 0,21 & 0,64 & 0,32 & 0,20 & 0,00 & - & - & - \\
\hline 7 & 1,23 & 1,11 & 1,62 & 0,83 & 0,55 & 1,22 & 0,00 & - \\
\hline 8 & 2,12 & 4,80 & 2,73 & 3,93 & 3,71 & 1,92 & 1,36 & - \\
\hline 9 & 11,47 & 13,72 & 3,56 & 0,00 & 7,82 & 0,00 & 0,00 & - \\
\hline
\end{tabular}

